Andrews University

Digital Commons @ Andrews University

2002

\title{
Empowering and Equipping the Laity in the South Caribbean Conference of Seventh-day Adventists
}

Ray Henderson Walker

Andrews University

Follow this and additional works at: https://digitalcommons.andrews.edu/dmin

Part of the Practical Theology Commons

\section{Recommended Citation}

Walker, Ray Henderson, "Empowering and Equipping the Laity in the South Caribbean Conference of Seventh-day Adventists" (2002). Professional Dissertations DMin. 605.

https://dx.doi.org/10.32597/dmin/605

https://digitalcommons.andrews.edu/dmin/605

This Project Report is brought to you for free and open access by the Graduate Research at Digital Commons @ Andrews University. It has been accepted for inclusion in Professional Dissertations DMin by an authorized administrator of Digital Commons @ Andrews University. For more information, please contact repository@andrews.edu. 


\section{ABSTRACT}

EMPOWERING AND EQUIPPING THE LAITY IN THE SOUTH CARIBBEAN CONFERENCE OF SEVENTH-DAY ADVENTISTS

by

Ray Henderson Walker

Adviser: R. Clifford Jones 
ABSTRACT OF GRADUATE STUDENT RESEARCH

Dissertation

Andrews University

Seventh-day Adventist Theological Seminary

Title: EMPOWERING AND EQUIPPING THE LAITY IN THE SOUTH CARIBBEAN CONFERENCE OF SEVENTH-DAY ADVENTISTS

Name of researcher: Ray Henderson Walker

Name and degrees of faculty chair: R. Clifford Jones, D.Min., Ph.D.

Date completed: July 2002

\section{Problem}

Some pastors in the South Caribbean Conference of Seventh-day Adventists feel challenged by the ministry of the laity. One reason is the lack of a clear understanding of the biblical and theological perspectives on empowering and equipping the laity. Consequently, the potential of the laity is not fully utilized.

\section{Method}

Current literature was reviewed. This included books and articles on the principles, strategies, and programs which assist pastors to develop their empowering and equipping skills. A comparison was done between the ministry of the 
pastors and the laity in the South Caribbean Conference of Seventh-day Adventists. An evaluation of selected equipping programs was completed. Seminars were developed for pastors to empower and equip the laity.

\section{Conclusions}

Empowering and equipping is an indispensable ministry in a church. To make it optional is to neglect the training of new church members, older church members, and church leaders. A church cannot have a positive influence in community services without a prayerful, systematic training of its membership. With carefully correlated ongoing church membership training, a church can have an effective ministry which will enrich its gospel commission. This is the challenge of the ministry of membership training.

The doctrines of spiritual gifts and the priesthood of all believers need to be understood by pastors and members. The mobilization of church members to exercise their ministry should be based on their areas of giftedness. The role of the pastor is many faceted. It is very clear that the main function is to equip the members to develop their own ministry in building up the church (Eph 4:11, 12). As members are equipped and empowered, they become liberated to perform ministry. 


\begin{abstract}
Andrews University
Seventh-day Adventist Theological Seminary
\end{abstract}

EMPOWERING AND EQUIPPING THE LAITY

IN THE SOUTH CARIBBEAN CONFERENCE

OF SEVENTH-DAY ADVENTISTS

\author{
A Dissertation \\ Presented in Partial Fulfillment \\ of the Requirements for the Degree \\ Doctor of Ministry
}

by

Ray Henderson Walker

July 2002 



\section{EMPOWERING AND EQUIPPING THE LAITY IN THE SOUTH CARIBBEAN CONFERENCE OF SEVENTH-DAY ADVENTISTS}

A dissertation

presented in partial fulfillment of the requirements for the degree Doctor of Ministry

by

Ray Henderson Walker


Whan B.r.Xes $\frac{\text { July } 23,2002}{\text { Date approved }}$ 
This dissertation is dedicated to the love and memory of my dear wife, Cheryl Annette, for her faithful support, devotion, and encouragement, not only during this project, but throughout my entire ministry. She was faithful to God and her family, a devoted wife and mother, who, sadly, due to her peaceful passing on April 7, 2002, was unable to see the completion of this dissertation and share in the joy of receiving my doctorate.

This is also dedicated to my precious daughter, Crystal Raynette, whom I love dearly, for her sweet patience and understanding, who became my main source of inspiration for completing this dissertation. 
TABLE OF CONTENTS

LIST OF FIGURES . . . . . . . . . . . . . . . . . . viii

ACKNOWLEDGMENTS . . . . . . . . . . . . . . . . . . $i x$

Chapter

1.

INTRODUCTION

Statement of the Problem . . . . . . . 3

Statement of the Task . . . . . . . . . 3

Justification for the Dissertation . . . 3

Purpose of the Dissertation . . . . . . 4

Limitations of the Dissertation . . . . 4

Overview of the Dissertation . . . . . . 4

Expectations of the Dissertation . . . 5

2. BIBLICAL AND THEOLOGICAL PERSPECTIVES FOR EMPOWERING AND EQUIPPING . . . . . . . . . 6

The Importance of Empowering and

Equipping . . . . . . . . . . . . . . 6

The Importance of Equipping the Laity . 8

The Need for Equipping . . . . . . . . 10

Definition of Equipping the Laity . . . 11

The Ministry of Jesus as a Model . . . . 13

Jesus' Ministry . . . . . . . . . . . 14

Principles of Jesus' Ministry . . . . 16

Prayer Life . . . . . . . . . . . 17

Compassion . . . . . . . . . . . 18

Servant Leadership . . . . . . . . 19

Evangelist . . . . . . . . . . 20

Pastor-Teacher . . . . . . . . . . 21

The Role of the Pastor . . . . . . . . 27

Pastor as Equipper . . . . . . . . . 27

The Priority of the Pastor . . . . . . . 33

Pastor as Teacher/Educator . . . . . . . 38

Pastor as Discipler . . . . . . . . . . 42

Pastor as Trainer . . . . . . . . . . 48

Pastor as Administrator . . . . . . . 49

Definition of Church Administration . 51

Principles of Administrative
Leadership . . . . . 56

Administrators' Gifts and Their Effects . 60 
3. CHURCH MINISTRY PROGRAMS IN THE SOUTH CARIBBEAN CONFERENCE . . . . . . . . . . . . 64

Adventism in Trinidad and Tobago . . . . . 64

Strategy Proposal . . . . . . . . . . . 67

Overview of Church Ministry Programs . . . 69

The Centralized Model . . . . . . . . 69

Advantages of the Centralized

Model . . . . . . . . . . . 70

Disadvantages of the Centralized
Model . . . . . . . . 71

The Small Group Model . . . . . . . . . 71

Disadvantages of the Small-Group
Model . . . 73

The Departmental Model . . . . . . . . 74

Advantages of the Departmental

Model . . . . . . . . . . . . 75

Disadvantages of the Departmental

Model . . . . . . . . . . . 75

Ministry in Trinidad and Tobago . . . . 76

Pastoral Crusades . . . . . . . . 76

Lay Crusades . . . . . . . . . . . . . 77

Review of Church Ministry Programs . . . 81

4. STRATEGIES TO EMPOWER AND EQUIP THE LAITY . . 84

Leading the Laity to Discover Their

Spiritual Gifts . . . . . . . . . . . . 84

Empowering and Equipping the Laity . . . . 94

Empowered Through the Word . . . . . . 95

Empowered Through Obedience . . . . . . 96

Empowered Through Prayer . . . . . . . 96

Empowered Through Relationship

With God . . . . . . . . . . . 96

Empowered Through Mutual

Participation . . . . . . . . . . . 97

Empowered Through Transformation . . . 98

Empowered by the Holy Spirit . . . . . 98

Equipping Process . . . . . . . . . . 102

Training . . . . . . . . . . . . 103

The Need for Training . . . . . . . 104

Training in Multi-Church Districts . . 106

Motivation . . . . . . . . . . . . 109

Christian Motivation . . . . . . . . 110

Motivation Strategy . . . . . . . . . . 113

Motivating the Laity to Witness . . . 115

Principles of Motivation . . . . . . .. 115

Developing Church Structures to

Facilitate a Shared Ministry . . . . . 123

Ministry: A Shared Responsibility . . 123

Strategy for a Shared Ministry . . . . . . 123

Ministry for the Whole Church . . . . . 123 
Pastors as Trainers of Lay

Leaders . . . . . . . . . . . : 125

Structure for a Shared Ministry . . 125

Smal1-Group Lay Ministry Program . . . . . 131

Recruiting and Training Lay Leaders . . 132

The Recruitment of Lay Leaders . . . . 133

Listing Qualities . . . . . . . 133

Selecting the Leaders . ... . . . 134

Contacting Leaders . . . . . . . . 135

Training the Lay Leaders . . . . 136

The Retreat . . . . . . . . . . . 136

A Seminar for the Laity . . . . . . . 137

Purpose . . . . . . . . . . . . . . 137

Participants . . . . . . . . . . 138

Goals . . . . . . . . . . . . 138

Schedule . . . . . . . . . . . . . . 139

Location . . . . . . . . . . . . . 140

Seminar Content . . . . . . . . . 140

Evaluation . . . . . . . . . . . . 141

Graduation . . . . . . . . . . . . 142

Expected Results . . . . . . . . . 142

5. DEVELOPING A GIFT-CENTERED MINISTRY . . . . . 143

Pastoral Qualities . . . . . . . . . . 143

Godly Character . . . . . . . . . . 144

Vision . . . . . . . . . . . . . . . 146

Influence . . . . . . . . . . . . . 149

The Love of Jesus . . . . . . . 151

Consecration . . . . . . . . . . 152

Humility . . . . . . . . . . . . . . 153

Earnestness . . . . . . . . . . . . 154

Responsibility . . . . . . . . . . . 154

Gift-Centered Ministry Means Equipping . . 155

Developing a Gift Ministry . . . . . . . . 155

Gift-Oriented Ministry Outline . . . . . . 157

Benefits of Equipping . . . . . . . . 164

Benefits to the Pastor . . . . . . . 165

Benefits to Church Members . . . . . 165

Why Some Pastors Fail in Equipping . . 166

How to Equip . . . . . . . . . . . 166

Training and Mobilizing Laity . . . . . . 167

Seminars for Pastors . . . . . . . . . 170

Purpose of the Seminars . . . . . . . 170

Participants in the Seminar . . . . . 171

Goals for the Seminars . . . . . . . 171

Description of the First Seminar . . . 172

Seminar Content . . . . . . . . . 172

Description of the second Seminar. . 174

Seminar Content . . . . . . . . . 174

Components of the Seminars . . . . . 174

Instructors for the Seminars . . . 175 
Evaluation of the Seminars . . . . . 175

Expected Results . . . . . . 175

6. SUMMARY, CONCLUSIONS, AND RECOMMENDATIONS . . 177

Summary • • • . . . . . . . . . . . . 177

Conclusions . . . . . . . . . . . . . . . 179

Recommendations . . . . . . . . . . . 181

APPENDIX . . . . . . . . . . . . . . . . . . . . . . . 183

A. EVALUATION OF THE SEMINAR BY THE LAITY . . 184

B. EVALUATION OF THE SEMINARS BY THE PASTORS • 186

BIBLIOGRAPHY . . . . . . . . . . . . . . . . . . . 188

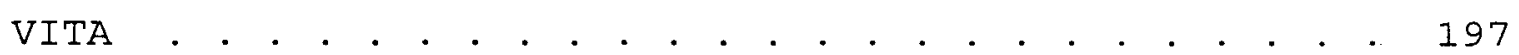

vii 


\section{LIST OF FIGURES}

1. The Jethro Model . . . . . . . . . . . . . . . . 128

2. Structure for Developing Small Group Unit Leaders 


\section{ACKNOWLEDGMENTS}

I sincerely express my gratitude and appreciation to the many persons who contributed to the completion of this project.

I am deeply grateful to my parents, Henderson and Yvonne Walker, for dedicating me to the Lord for ministry, and to my siblings, and family members for their prayers, support, and encouragement.

I thank the South Caribbean Conference of Seventh-day Adventists for supporting me during my ministry and granting study leave.

I thank my friends for their encouragement.

of the many individuals who made valuable contributions to this study, I thank Dr. R. Clifford Jones, chairman of my doctoral committee, for being accessible and supportive, who gave of his time and provided guidance and encouragement in developing this dissertation. Thanks also to Dr. Eduard E. Schmidt, the second adviser, who gave his time, valuable suggestions, and assistance in making this project possible; and Dr. Walter B. T. Douglas, the third reader, for his guidance and helpful suggestions. I also thank Dr. Skip Bell, Director of the Doctor of Ministry program, for his kind contributions. 
I owe a great debt to Bonnie Beres, who gave of her skills and time to type this dissertation. I express my profound thanks to Bonnie Proctor, the dissertation secretary, for her timely assistance with the editing.

Above all, I thank God for His love, guidance, and inspiration throughout my life. Truly, all I have achieved is as a result of His blessings. To God be all glory, praise, and honor. 
CHAPTER 1

\section{INTRODUCTION}

I worked as a pastor/evangelist with the South Caribbean Conference of Seventh-day Adventists from April 1984 to August 1988. During that time, it was a privilege to equip my members for ministry. However, I concluded that pastors were not fully trained to empower and equip the laity to reach their fullest potential in ministry. It was always my desire to develop a program that would assist pastors to better empower and equip the laity.

There are two main reasons why I decided to focus on "Empowering and Equipping the Laity in the South Caribbean Conference of Seventh-day Adventists" for my Doctor of Ministry dissertation.

1. I believe that ministry is a shared experience between pastors and laity.

2. My interest in the subject was heightened when I did the following Christian Ministry courses: (a) Seminar in Leadership, (b) Equipping Lay Leaders for Church Growth, (c) Evangelism and Church Growth, and (d) Techniques in Church Planting. 
In addition, I believe that the high expectations the laity have of pastors have made pastoral work, especially in multi-church districts, a very challenging experience. There are some pastors who do not fully understand and accept the fact that all members play an important role in their ministry.

An important role of the pastor is that of motivating, equipping, and empowering members to perform ministry in their areas of giftedness and abilities.

The empowerment of laity and clergy to become active co-workers as God's people is the key to a vital church tomorrow. If God's mission is to be furthered through the church's ministry, then a way must be found to engage more of God's people in ministering to one another and to the world's needs. ${ }^{1}$

Even though all members are not called or gifted to minister in leadership positions as pastors, elders, or teachers, ministry is for every member. ${ }^{2}$ Indeed, both pastors and laity should recognize the need of each other so that ministry can be more effective and meaningful to the church.

I believe that a better understanding of the biblical teaching on empowering and equipping the laity would strengthen the ministry of both pastors and laity. This dissertation could be the beginning of such progress.

\footnotetext{
${ }^{1}$ Alvin J. Lindgren and Norman Shawchuck, Let My People Go: Empowering Laity for Ministry (Nashville: Abingdon, 1980), 13 .

${ }^{2}$ Martin Bobgan and Deirdre Bobgan, Competent to Minister: The Biblical Care of Souls (Santa Barbara, CA: East Gate, 1996), 34 .
} 
Statement of the Problem

Some pastors in the South Caribbean Conference of Seventh-day Adventists feel challenged by the ministry of the laity. One reason is the lack of a clear understanding of the biblical and theological perspectives on empowering and equipping the laity. Consequently, the potential of the laity is not fully utilized.

\section{Statement of the Task}

The task of this dissertation is to discover a clear understanding of the biblical and theological perspectives for empowering and equipping the laity in the South Caribbean Conference of Seventh-day Adventists.

\section{Justification for the Dissertation}

The New Testament model of ministry teaches the concept of the priesthood of all believers. Since both ministers and lay persons belong to the priesthood of all believers, they need to work together closely. In order to facilitate this cooperation, pastors and laity need to have their respective roles clearly defined.

When church members have not been fully trained as effective missionaries of Jesus Christ, they often end up depending on pastors to do ministry. On the other hand, when the members are properly equipped, they fulfill their own ministry without being in competition with the pastor's ministry. 


\section{Purpose of the Dissertation}

The purpose of this dissertation is to develop pastoral seminars for empowering and equipping the laity in the South Caribbean Conference of Seventh-day Adventists.

\section{Limitations of the Dissertation}

This dissertation was limited to the challenges of pastoral ministry in the context of the South Caribbean Conference. Although pastoral ministry involves different functions, the study focuses primarily on the area of the pastor's ability to empower and equip the laity.

\section{Overview of the Dissertation}

Current literature was reviewed. This included books and articles on the principles, strategies, and programs which assist pastors to develop their empowering and equipping skills. A comparison was done between the ministry of the pastors and the laity in the South Caribbean Conference of Seventh-day Adventists. An evaluation of selected equipping programs was done.

Chapter 2 discusses the biblical and theological perspectives for empowering and equipping the laity.

Chapter 3 presents analyses of church ministry programs in the South Caribbean Conference.

Chapters 4 and 5 deal with the design and implementation of pastoral seminars to empower and equip the laity. 
5

Chapter 6 outlines the summary, conclusions, and recommendations of the project.

\section{Expectations of the Dissertation}

1. This project will enable me to develop my empowering and equipping skills as a pastor when I return to the South Caribbean Conference of Seventh-day Adventists.

2. This project can educate the church members to become more active in ministry.

3. This project will help pastors in the South Caribbean Conference of Seventh-day Adventists better understand the biblical and theological perspectives on empowering and equipping.

4. This project will provide strategies for pastors to better empower and equip their members for ministry. 
CHAPTER 2

\section{BIBLICAL AND THEOLOGICAL PERSPECTIVES FOR EMPOWERING AND EQUIPPING}

\section{The Importance of Empowering and Equipping}

"Empowering God's people, as individuals and as a community, is the foundation of a fruitful ministry. Pastors who have been empowered, and who focus on empowering others, are much more likely to be effective."1

Why is empowering so important? Because it is, in effect, the heart or essence of the gospel. To empower people is to release power in their lives. A ministry that focuses on empowering connects people to God's resources for living and frees them from bondage to a meaningful experience in ministry. When the pastor's ministry focuses on empowerment, wholeness is engendered in the lives of God's people. To be sure, empowering is different from "enabling." The cliché of an "enabling ministry". has led some pastors to move in the direction of a laissez-faire approach to their members. This leads only to weakness, not empowerment.

${ }^{1}$ Donald P. Smith, Empowering Ministry: Ways to Grow in Effectiveness (Louisville, KY: Westminster John Knox Press, 1996), 8 . 
Lyle schaller contrasts leadership that initiates with leadership that enables. His clear implication is that enablers do not initiate. ${ }^{1}$ True leadership does not reinforce weakness and dependency, but empowers. Empowering individuals or institutions is to unleash their power. It is to inspire, nurture, and serve people in such a manner that they achieve the fullest potential for ministry. Empowerment challenges people to move out into the world to be effective witnesses. As such, empowerment fulfills gospel faithfulness. This is a challenge for leadership that requires initiative from highly skilled and dedicated leaders. Empowering responds to the deep needs of people with God's resources.

Empowering pastors love the people to whom they minister. They believe in them and trust them. Pastors who empower encourage and reinforce people's ability to choose. They give them time to own and accept new possibilities. They help them consider options, facilitate choices, and weigh potential directions. A very important characteristic of empowering is that members are able to discover their giftedness.

One of the challenges of empowering God's people is that "equipping the saints for the work of ministry" is not the equivalent of having equipped saints empowered and

${ }^{1}$ Lyle Schaller, The Senior Minister (Nashville: Abingdon Press, 1988), 26. 
released for ministry. Oftentimes, equipped saints cannot fully function because they are not given the opportunity or support/affirmation to perform their ministry. This style of leadership has prevented many churches that have adopted an "equipping" style of ministry from reaching their potential. I concur with Balswick and wright that "from a Biblical perspective, all styles of leadership must be characterized by an attempt to empower rather than to dominate and control."1

\section{The Importance of Equipping the Laity}

Why is equipping the laity so important? There are five main reasons. First, the Bible makes it clear that the main function of the pastor is to "equip the saints for the work of ministry" (Eph 4:11-12). Second, pastors will reduce the danger of burnout and family alienation. Unequipped church members tend to depend too much on the pastor's ministry and not the development of their ministry.

The Bible teaches the delegation of responsibilities so that both leaders and members will work more effectively. This is referred to as the Jethro principle of leadership. Jethro said to Moses, "This task is too heavy for you; you cannot do it alone. You will surely wear yourself out" (Exod 18:18), and he counseled Moses to appoint proper

'Jack Balswick and Walter Wright, A ComplementaryEmpowering Model of Ministerial Leadership (Pasadena, CA: Fuller Theological Seminary, 1987), 1. 
persons as rulers of thousands, and others as rulers of hundreds, and others of tens (vs. 21) to bring relief to Moses. The appointed individuals were to help bear the burden with Moses (vs. 23). This principle should be applied more among the ministry in Trinidad and Tobago where the equipping of the laity will also promote church growth.

Ellen White emphasizes the importance of equipping the members to carry the work of ministry: "If pastors would give more attention to getting and keeping their flock actively engaged at work, they would accomplish more good, have more time for study and religious. visiting, and also avoid many causes of friction." 1 In other words, equipping the laity encourages church members to grow spiritually. Third, if the pastor does not equip the laity, they will become religious dwarfs. Ellen white stated that as long as church members make no effort to give others the help given them, great spiritual feebleness will result. The greatest help that can be given the people is to teach them to work for God and to depend on Him, not on the minister. ${ }^{2}$ Pastors in the South Caribbean Conference need to equip the laity to reach their fullest potential in the church so that the laity will develop in their areas of giftedness.

${ }^{1}$ Ellen G. White, Gospel Workers (Washington, DC: Review and Herald, 1948), 200.

${ }^{2}$ Ellen G. White, Testimonies for the Church (Mountain View, CA: Pacific Press, 1948), 7:18-19. 
Fourth, pastors should equip volunteers, since it saves tithe money. Pastors need to know what Kilcher says:

Ten members in volunteer ministry are equivalent to one full-time staff person. Yet most churches are underutilizing their available people-power by 80 percent. If every member in a church of 200 members were motivated to find his/her place of ministry, the church would add the equivalent of 16 full-time pastors to the staff.

Fifth, equipping the laity is always needed and should be ongoing because (1) some new members always need training; (2) new knowledge is: always uncovered that members should have; (3) people are always devising new and better methods; (4) new church officers are always being elected who need training; and (5) new communities are always awaiting to be reached. ${ }^{2}$

\section{The Need for Equipping}

Members need to be equipped for the following reasons:

1. To prevent them from getting involved in activities they are not gifted for

2. To become actors and not spectators

3. To perform at maximum performance standards

4. To prevent them from becoming gossipers

${ }^{1} \mathrm{C}$. Raymond Holmes and Douglas Kilcher, eds., The Adventist Minister (Berrien Springs, MI: Andrews University Press, 1991), 100 .

${ }^{2}$ Ricardo Norton, Class notes, CHMN664 Equipping Lay Leaders for Church Growth, Andrews University, Berrien Springs, MI, spring 1999. 
5. To prevent them from becoming nominal Christians.

It is the pivotal factor that leads the church in active ministry, which ultimately leads to the growth of the church. Church leaders should not expect the laity to assume leadership responsibility without adequately empowering and equipping them.

\section{Definition of Equipping the Laity}

The apostle Paul uses the term "equipping" (katartismos) in Eph 4:11, where it means "discipling," "perfecting," and "nurturing." The word and its derivatives may also carry the sense of "put in order" or "restore something to its former condition," such as cleaning, mending, folding together, or "to make something complete." When applied to people, it means to complete their training or to prepare them for something. ${ }^{2}$

Peter Wagner defines the term "equipper" as "a leader who actively sets goals for a congregation according to the will of God, obtains goal ownership from the people, and sees that each church member is properly motivated and equipped to do his or her part in accomplishing the goals." 3

'Norton, Class lectures.

${ }^{2}$ William F. Arndt and F. Wilbur Gingrich, A Greek-English Lexicon of the New Testament and Other Early Christian Literature (Chicago: University of Chicago Press, 1979), 418.

${ }^{3} \mathrm{C}$. Peter wagner, Church Planting for a Greater Harvest (Ventura, CA: Regal Books, 1990), 131-132. 
As an equipper, the pastor is to create an atmosphere where both the pastor and members experience a shared ministry. The apostle Paul believes that the saints, even those who are not "pastor-teachers," have a role to play in ministry. The pastor-teacher has a responsibility to equip the saints or laity to do the work of ministry. The purpose of the "equipping of the saints for the work of ministry" is to enable the person to carry out God's purposes, which is the extension of His kingdom throughout the world. The equipping of the saints is synonymous with discipling. Those who are equipped for ministry are those who are fully discipled. This emphasis on equipping saints for ministry focuses on the individual rather than on the congregation. It emphasizes individuals fulfilling their giftedness rather than just doing church programs.

God's intention from creation has been to have a relationship with humankind. This relationship would involve the empowering of His people for ministry. It is only through the power of the Holy spirit that the church and its leaders can equip, empower, encourage, and send forth the saints for the work of ministry in the church, the community, and the world.

An important question is, what difference will an equipping ministry have in the experience of a church? An equipping ministry should enable a church to attain a higher quality of ministry because it harnesses the spiritual gifts 
within a congregation. Once the gifts are identified and put to use, a dynamic ministry will be accomplished through the laity.

An equipping ministry relieves the preaching minister of a tremendous psychological burden. One of the greatest anxieties among ministers is the fear of failure. The finger of responsibility is often pointed toward the pulpit when congregational shortcomings occur. In an equipping ministry responsibility is mutually shared.

An equipping ministry enables Christians to discover and utilize their giftedness. As a result, they experience satisfaction in the service of Christ.

\section{The Ministry of Jesus as a Model}

The essential concept of ministry in the church stems from the life and work of Jesus Himself. "The son of man," Jesus said, "came not to be served but to serve" (Mark 10:45). This statement is very important in any study of an equipping ministry.

As we examine the Gospels we see that Jesus practiced an equipping style of ministry. First, He found others to minister. "He found Philip," John records, "and said to him, 'Follow me'" $(1: 43)$. Jesus continued to discover others who could minister. Some did not respond because they were not willing to make a sacrificial commitment to ministry in the building of the kingdom of God (Luke 9:5762). 
Jesus equipped His followers by loving them (John 13:1), by teaching them (Matt $5: 2$ ), by praying for them (Luke 22:39-41), and by training them on the job (Matt 10:5ffi Luke $10: 1 f f$.$) . Equipping the laity was a key to the$ ministry of Jesus. The mission of the twelve and of the seventy shows elements of training. Matthew says, "These twelve Jesus sent out" (10:5); Luke writes, "After this the Lord appointed seventy others, and sent them on ahead of him" (10:1). Notice they were called to be sent. In effect, they were equipped and empowered to do ministry. Jesus equipped others to perform their own ministry.

\section{Jesus' Ministry}

Jesus' earthly ministry reveals various qualities of service that inform the church's understanding of pastoral ministry. These characteristics are call to ministry, service in ministry, self-emptying, obedience, and selfsacrifice.

First, the pastor is called by God and shaped by that call. H. Richard Niebuhr still provides the classic definition of the call to ministry. He describes it as having four parts:

a. The call to be a Christian, which is variously described as the call to discipleship with Jesus Christ, to hearing and doing the word of God, to repentance and faith

b. The secret call, namely that inner persuasion or experience whereby a person feels him/herself directly 
summoned or invited by God to take up the work of the ministry

c. The providential call, which is that invitation and command to assume the work of the ministry which comes through the equipment of a person with the talents necessary

d. The ecclesiastical call, that is, the summons and invitation to a person by some community or institution of the church to engage in the work of ministry. ${ }^{1}$

Second; Jesus' servanthood shows that within the scope of ministry is to serve the poor and needy, not to seek reward. Jesus' clear and powerful message that $\mathrm{He}$ is the one who is hungry, the one who is thirsty, the stranger, the naked, the sick, and the imprisoned can never be overstated (Matt 25:31-46). Third, the call from God and the practice of ministry involve giving up or "emptying" oneself. In other words, caring for others instead of oneself.

Fourth, the pastor obeys God as Master. The master/ servant relationship is very old. It requires that servants (slaves) give total obedience to the commands of the master. To be sure, in ministry many challenges beckon for our attention. Included are the family, congregation, church organization, or sometimes the community.

Fifth, Jesus' death on the cross is a reality that pastors must not deny. When the message of the cross is

${ }^{1} \mathrm{H}$. Richard Niebuhr, The Purpose of the Church and Its Ministry (New York: Harper and Bros., 1956), 64. 
presented in its right perspective, members will be empowered by church leaders and the Holy Spirit to do ministry.

What else could we learn from Jesus' ministry that equips and empowers us for service? Surely Christ's servant-leadership has many more lessons for ministry. Jesus taught His disciples that the greatest in His kingdom was one who was willing to be a servant to others. Jesus modeled this teaching in His own ministry.

In addition, Jesus had a clear vision of His mission and worked to achieve His goals. Yet, while He was concerned about human needs, He was always mindful of revealing His Father's will.

Jesus also elevated the priority of servanthood as the prerequisite for Christian leadership (Mark 10:42-45). Christian leadership is exemplified in the ministry of Jesus, who was the perfect model. Leadership is Spiritempowered submission to God and service (ministry) to the people of God for the advancement of the kingdom of God.

\section{Principles of Jesus' Ministry}

Christ was the perfect model for the pastors in the world today. Ellen White emphasizes that pastors should follow the example of Jesus' ministry.

- Christ is the Chief shepherd. He has intrusted the care of His flock to under shepherds. . . . He has solemnly commanded these to be faithful shepherds, to feed the flock with diligence, to follow His example, to strengthen the weak, nourish the fainting, and to 
shield them from devouring beasts. He points them to His example of love for His sheep. To secure their deliverance, He laid down His life for them. If they imitate His self-denying example, the flock will prosper under their care."

Six principles of Jesus' ministry which are critical to any pastoral model for successful ministry are:

\section{Prayer Life}

Intercessory prayer was very important to Christ's ministry. He lived a meaningful prayer life. The Bible teaches, "And in the morning, rising up a great while before day, he went out, and departed into a solitary place, and there prayed" (Mark 1:35). Luke records, "And he came out and went, as he was wont, to the mount of Olives; and his disciples also followed him. And when he was at the place, he said unto them, Pray that ye enter not into temptation. And he was withdrawn from them about a stone's cast, and kneeled down and prayed" (Luke 22:39-41). Jesus prayed every day. ${ }^{2}$ Jesus' prayer in luke 22 points out a very salient point of knowing that, just as God sent an angel "not to take the cup from Christ's hand, but to strengthen Him to drink it," so He will empower us. ${ }^{3}$

${ }^{1}$ Ellen G. White, Pastoral Ministry (Silver Spring, MD: General Conference of Seventh-day Adventists, 1995), 281.

${ }^{2}$ White, Testimonies for the Church, $2: 201$.

${ }^{3}$ Ellen G. White, The Desire of Ages (Mountain View, CA: Pacific Press, 1940), 693-694. 
As we study the prayer life of Jesus, we discover, as Ellen White says, "He was not praying for Himself, but for those whom He came to save. . . Morning by morning, and evening by evening, He prayed so that daily He could receive a fresh baptism of the Holy Spirit's grace, and fervor to impart to others."1 Jesus prayed for people.

Our Saviour identified Himself with our needs and weaknesses; in that He became a suppliant, a petitioner, seeking from $\mathrm{His}$ Father fresh supplies of strength, that He might come forth braced for duty and trial. . . He found comfort and joy in communion with His Father. And if the saviour of men, the son of God, felt the need of prayer, how much more should feeble, sinful mortals feel the necessity of fervent, constant prayer. ${ }^{2}$

\section{Compassion}

Jesus' love for people is clearly demonstrated by His miraculous acts of ministry as recorded in the Gospels. "But when He saw the multitudes, He was moved with compassion for them, because they were weary and scattered, like sheep having no shepherd" (Matt 9:36). His demonstration of sympathy was both by precept and example. "He Himself took our infirmities. And bore our sicknesses" (Isa $53: 4 ;$ Matt $8: 17$ ).

"For God so loved the world that He gave His only begotten Son, that whoever believes in Him should not perish but have everlasting life" (John 3:16).

\footnotetext{
${ }^{1}$ White, Pastoral Ministry, 282-283.
}

${ }^{2}$ Ellen G. White, steps to Christ (Mountain View, CA: Pacific Press, 1956), 93, 94. 
Ellen White says that "Christ identified Himself with the necessities of His people. Their needs and their suffering were His." ${ }^{1}$ The followers of Christ are to labor as He did. We are to feed the hungry, clothe the naked, and comfort the suffering and afflicted. . . Often the heart will harden under reproof; but it will melt under the love of Christ." 2

\section{Servant Leadership}

At Jesus' baptism in the River Jordan, there was a heavenly declaration as follows: "Thou art my beloved son, with whom I am well pleased" (Mark 1:11). These words are a fulfillment of Isa $42: 1$, "Behold my servant whom I upheld, my chosen, in whom my soul delights," which addresses the servant of God and identifies Jesus as the fulfillment of the old Testament prophecy. Jesus Himself taught the disciples that "the son of Man came not to be served but to serve, and to give his life as a ransom for many" (Matt $21: 28)$.

There are four servant Songs in Isaiah (42:1-4; 49:1-6; $50: 4-7 ; 52: 13-53: 12)$ which describe the characteristics of Jesus Christ as a servant. In these passages there are three main themes: obedience, wi.tness, and endurance. The servant, as described in those passages, is obedient to God

\footnotetext{
${ }^{1}$ White, Pastoral Ministry, 283.

${ }^{2}$ White, The Desire of Ages, 350-351.
} 
(42:1; 50:4-5), witnesses both to Israelites and the Gentiles (49:6), and suffers pain and agony (50:5-6). Although the Servant, Jesus Christ, is innocent, He offers Himself and bears the sins of the people (53:11-12), and God will accept His sacrifice and vindicate His cause (53:1012).

Ellen White says that Jesus has given marked lessons in humility to all, but especially to the gospel minister. She also says, "If ministers have trials, perplexities, and temptations, they should know that there is one who has endured all these before them," as the apostle Paul said in Heb $12: 2-3.1$

\section{Evangelist}

Ellen White emphasized that "Christ came to give a correct example of a gospel minister. He labored constantly for one object; all His powers were employed for the salvation of men." 2 Jesus Himself said, "For the son of man came to seek and to save the lost" (Luke 19:10).

Jesus' strategy for evangelism is outlined in the following statement.

Christ's method alone will give true success in reaching the people. The savior mingled with men as one who desired their good. He showed His sympathy for

${ }^{1}$ White, Pastoral Ministry, 284.

${ }^{2}$ Ibid. 
them, ministered to their needs, and won their confidence. Then He bade them, Follow Me.'

Thus, the steps of Jesus' method of evangelism were:

1. to mingle with people

2. to show sympathy for them

3. to minister to their needs

4. to win their confidence

5. to bid all "Follow Me."

Jesus spent His ministry applying these principles of evangelism. Healing was one of the main methods Jesus used to save people. "During His ministry, Jesus devoted more time to healing the sick than preaching. His miracles testified to the truth of His words, that He came not to destroy, but to save." 2

\section{Pastor-Teacher}

Jesus was not just an ordinary pastor or preacher, but a teacher par excellence. His equipping of the twelve disciples proved that He was the Master Teacher. He chose disciples who were mainly poor, humble fishermen of Galilee, teaching them for three and one half years. The Bible records, "When they saw the boldness of Peter and John, and perceived that they were uneducated, common men, they

${ }^{1}$ Ellen $\mathrm{G}$. White, The Ministry of Healing (Mountain View, CA: Pacific Press, 1958), 143.

IIbid., 19. 
wondered; and they recognized that they had been with Jesus" (Acts $4: 13)$.

Jesus ministered to people not for who they were, but who they could be 'by the grace of God. 'Jesus' theme of teaching was that "in every human being, however fallen, He discerned infinite possibilities. He saw men as they might be, transfigured by His grace."1 As a consequence, people long to be in the presence of Jesus.

The teaching style of Jesus was plain and simple, so that all could understand. His illustrations were from the practical things of life, especially those of nature. When His hearers chanced to see the things from their daily Iives or nature, they recalled His immortal truth. ${ }^{2}$

Jesus prepared Himself for His ministry. He prayed and fasted for forty days in special preparation for His ministry. His entire life was one of planning to proclaim the gospel (Matt $4: 1,2$ ).

Jesus selected and recruited volunteers, organizing them for His ministry. In training those who would eventually become apostles, "He said to them, 'Come! Follow Me and I will make you fishers of men'" (Matt 4:19). After He equipped them, He empowered twelve. The Bible says, "He

${ }^{1}$ Ellen G. White, Education (Mountain View, CA: Pacific Press, 1952), 80 .

${ }^{2}$ White, Pastoral Ministry, 285-286. 
appointed twelve to be with Him, that He might send them out to reach" (Mark $3: 14)$.

Jesus implemented.His training by commissioning the twelve but also the other seventy. Jesus "called the twelve, whom $\mathrm{He}$ began to send out two by two". (Mark 6:7). Likewise, the Lord commissioned seventy others, whom He sent ahead of Him two by two into every. town and community that He planned to visit (Luke 10:1).

Jesus regrouped His disciples, listened to them and evaluated their reports. The Bible says, "The apostles gathered around Jesus and reported to Him everything they had done and taught. The seventy also returned and said, 'Lord, even the demons are subject to us in Your name. . . . However do not rejoice but the spirits submit to you but rejoice because your names are written in heaven' " (Iuke $10: 17,20)$.

As a person takes a closer look at the ministerial training model of Jesus, the following principles may be outlined. These are discussed by Robert Coleman in The Master Plan of Evangelism in a very practical manner.

Selection

Jesus called a few men who could bear witness to His life and continue His ministry after His ascension. These men were "unlearned and ignorant" according to the world's

${ }^{1}$ Robert E. Coleman, The Master Plan of Evangelism (Grand Rapids: Fleming H. Revell, 1994), 27-116. 
standard (Acts $4: 13$ ), but they were teachable. To them Jesus said, "Follow me and I will make you fishers of men" (Matt 4:19). Ellen. White says, "For the carrying out of His work, Christ did not choose the learning and eloquence of the Jewish Sanhedrin or the power of Rome. . . The Master chose humble, unlearned men. . . . These men He purposed to train and educate. . . They in turn were to educate others." 1

Association

Having called His men, Jesus made a practice of being with them. This was the essence of His training program-just letting His disciples follow $\mathrm{Him}$. It was by virtue of this fellowship that the disciples were permitted "to know the mysteries of the Kingdom of God" (Luke 8:10). Knowledge was gained by association before it was understood by explanation. ${ }^{2}$

"It was by personal contact and association that Jesus trained His disciples. Sometimes he taught them, sitting among them on the mountainside, sometimes beside the sea, or walking with them by the way." ${ }^{3}$

${ }^{1}$ Ellen G. White, Acts of the Apostles (Washington, DC: Review and Herald, 1946), 17.

${ }^{2}$ Coleman, 41,42 .

${ }^{3}$ White, The Desire of Ages, 152. 
Consecration

The experience of being consecrated involves commitment, dedication, and sacrifice to the "calling" of God. Jesus expected His disciples to be obedient and loyal to His mission. The willingness to deny themselves and take up their crosses and follow Jesus was crucial in their becoming equipped and empowered for ministry (Mark 8:34-38; Matt 16:24-26; Luke 9:23-25; John 12:25, 26). The experience of the cross demonstrates Christ's commitment to do His Father's will. Likewise, His followers must be willing to do His will (Mark 3:35; Matt 12:50).

Impartation

This aspect of Jesus' ministry involved the sharing of concepts, principles, and instructions. The objective of Jesus' teachings to His disciples was to reveal His Father and demonstrate that the Spirit would prepare them for ministry (Matt 10:19, 20; Mark 13:11; Luke 12:12).

Demonstration

Christ taught by precept and example. Jesus showed His disciples what it meant by living to bring glory to God and being a blessing to humanity (Luke 2:52). The disciples witnessed and were able to model His prayer life, His use of the Holy Scriptures, and His soul-winning methods. Indeed, truth for the disciples was not just a concept but a relationship with the Master Teacher (John 14:6). 
Delegation

Jesus believed in empowerment. He was mindful of the fact that His disciples had to be given responsibilities to develop their ministry. He began by equipping and empowering them with His own authority and power to do His work (Mark 6:7; Matt 10:1; Luke 9:1, 2). As the disciples were delegated to do ministry, they were to remember that the Holy Spirit was God's agent of empowerment for them (Acts $1: 8)$.

Supervision

Christ continued to give guidance to His disciples. The assurance of knowing that Jesus was their teacher and that He was always with them for regrouping, review, and evaluation of their missions was a source of strength for them to continue their ministry. For example, the twelve were anxious to report to Jesus (Mark 6:30; Luke 9:10). "The seventy returned rejoicing, and said, 'Lord, even the demons obeyed us when we rebuked them in your name" (Luke 10:17). The feeding of the multitude demonstrated Christ's supervision of the disciples. In addition, it taught them an important lesson for spiritual discernment (Mark 6:30-44; Matt 14:13-21; Luke 9:10-17; John 6:1-13).

Reproduction

This aspect of training is surely the key to continued growth. Christ expects His followers to reproduce His 
character in other disciples who would extend the kingdom of God. The Great Commission sums up the goal of equipping and empowering (Matt 28:19, 20).

\section{The Role of the Pastor}

As one examines the many-faceted functions of pastors, it is very clear that their main function is to equip the membership to develop their own ministry in building up the church (Eph $4: 11,12$ ).

\section{Pastor as Equipper}

As members are equipped and empowered, they become liberated to perform ministry. Ellen white says, "The best thing the pastor can do for the members is not sermonizing but educating and planning work for them to do."1

In a similar vein, Greg Ogden says, "If the church is to be a ministering community, the pastor must be an equipper who empowers God's people to fullness of service. - The biblical emphasis is not on the omnicompetent pastor, but a multi-gifted body."2

The importance of pastors empowering and equipping. the laity cannot be overemphasized. It is critical for pastors to be willing to become liberators of the laity for

${ }^{1}$ Ellen G. White, Christian Service (Washington, DC: Review and Herald, 1947), 69.

${ }^{2}$ Greg Ogden, The New Reformation: Returning Ministry to the People of God (Grand Rapids, MI: Zondervan, 1990), 85, 75 . 
ministry. In fact, both the pastors and laity benefit as a result of the equipping ministry.

Peter Wagner describes an equipping leader as: "A leader who actively sets goals for the congregation according to the will of God, obtains goal ownership from the people, and sees that each church member is properly motivated and equipped to do his or her part in accomplishing the goals."1

In order for pastors to be effective equippers, they must set goals for the church members, motivating and empowering them with the necessary tools to function in their ministry according to their giftedness.

There are several reasons why pastors should become effective, equipping pastors.

"The preaching minister who adopts the equipping ministry needs to realize he is operating on an entirely different principle than the one-person-clergy concept. It is extremely important for him/her to have a clear understanding of his/her role."2

The pastor has to change his/her concept about the laity and view them as part of ministry. When pastors view the laity as such, there will be a greater use of their

${ }^{1} \mathrm{C}$. Peter Wagner, Leading Your Church to Growth (Ventura, CA: Regal, 1984), 79 .

${ }^{2}$ Paul Benjamin, The Equipping Ministry (Cincinnati, OH: Standard Pub., 1978), 55. 
talents in a shared ministry. "The equipping ministry continually prepares others for the work to be done." 1

As pastors develop their equipping abilities, thereby empowering the laity for their particular ministries, the ministry of the church will have a wider influence inwardly and in the broader community. As pastors make proper use of the main resource of the church--the laity--pastors will begin to better appreciate the equipping ministry.

"When he (the pastor) discovers natural talents and gifts of the spirit which have been distributed among God's people, equips the people, and leads them into their various ministries, he accomplishes the biblical teaching of the priesthood of all believers (1 Pet 2:5, 9)."2

The importance of helping members to discover their spiritual gifts is critical to the success of the pastor empowering and equipping the laity. The gifts of the laity only need to be developed and used properly to be a blessing to the church family.

Ellen White says that "the greatest help that can be given to our people is to teach them to work for God and to depend on $\mathrm{Him}$, not on the ministers." ${ }^{3}$ As pastors equip and empower the church members, the church will become a

\section{${ }^{1}$ Ibid.}

${ }^{2} \mathrm{~K}$. Lavern Snider, Whose Ministry? A Group Study Book on the Ministry of Every Christian (Osaka, Japan: Free Methodist. Mission, 1975), 89.

${ }^{3}$ White, Testimonies for the Church, $7: 19$. 
"spiritual giant" to be reckoned with. On the other hand, if pastors try to do all the work, allowing the members to be spectators and not participants, there will be very little growth in the church. "Ministers can never perform the work that the church should do."1

"Let the ministers teach church members that in order to grow in spirituality they must carry the burden that the Lord has laid upon them." 2

Russell Burrill states that most church-growth specialists assert the role of the pastor must be that of a trainer or equipper. ${ }^{3}$

Equipping and empowering members keeps the pastor focused on understanding the biblical teaching of the priesthood of all believers. When pastors realize that ministry does not belong only to them, but that every member has a ministry to perform, ministry then is experienced differently and is more meaningful and productive to the entire body of believers.

Equipping the members enables the pastor to train them in the area of spiritual gifts. However, the pastor must always be conscious that it is the Holy Spirit who bestows

${ }^{1}$ Ibid. , $4: 69$.

${ }^{2}$ White, Gospel Workers, 200.

${ }^{3}$ Russell Burrill, Revolution in the Church (Fallbrook, CA: Hart Research Center, 1993), 50. 
the various gifts upon the members for the building of the church, the body of Christ.

Barna asserts that the pastor's role as an equipper carries the responsibility of assisting church members in discovering, developing, and implementing their spiritual gifts. He affirms that the role of the pastor includes the following: (1) to identify those gifts and talents, (2) to refine those gifts by training, (3) to provide opportunities for the individual to utilize those gifts in a significant ministry, and (4) to support the individual in that ministry is an ongoing process. ${ }^{1}$

Equipping the laity encourages the pastor to develop proper time management and delegation skills. Norton states that lay participation can be a powerful activity to promote growth in a church, improve performance, and grant more respect and authority to ministers. It can also bring a variety of new gifts to the church which would otherwise remain dormant. Delegation not only distributes the work of the minister (Exod 18:22), but gives him/her more time for other important duties. ${ }^{2}$

Carl George says that successful pastors recognize the need for laity to function as team leaders, and that pastors must arrange their ministry around the concept that God does

${ }^{1}$ George Barna, User Friendly Churches (Ventura, CA: Regal, 1992), 1.

${ }^{2}$ Norton, Class notes. 
not want them to do everything themselves, but depends on the laity to minister also. ${ }^{1}$

The pastor-equipper model enables the pastor to develop the teaching ministry in a more effective manner. As a result, discipleship becomes an integral part of ministry, thereby fulfilling the great commission (Matt 28:18-20).

Equipping is an ongoing process for church members. The pastor-equipper is always needed for the following reasons: (1) new members need training; (2) training provides new knowledge and tools for all members; (3) equipping introduces new and better methods to use and implement; (4) new church officers need training; (5) new people groups or communities need to be reached; and (6) the work of equipping and perfecting the saints takes a lifetime. ${ }^{2}$

It should be noted that "equipping" is not delegating so that the pastor can get more done. Equipping is training and giving over the ministry to the people who really should be doing it in the first place. This is the key to God's divine game plan for the church. ${ }^{3}$

When the pastor equips and the people minister, two divine objectives are fulfilled. The first is that the

${ }^{1}$ Carl F. George, Prepare Your Church for the Future (Grand Rapids: Fleming H. Revell, 1996), 120.

${ }^{2}$ Norton, Class notes.

${ }^{3} \mathrm{R}$. Paul Stevens, The Equipper's Guide to Every-Member Ministry (Downers Grove, IL: InterVarsity Press, 1992), 10-15. 
local body of believers experiences the unity of the faith. "When believers are properly taught, when they faithfully do the work of service, and when the body is built up in spiritual maturity, unity of the faith is an inevitable result." 1 The second result of following God's pattern for building His church is that the knowledge of the son of God is attained.

Gary Tangeman emphasizes that

equipping people for ministry must be the priority of every church and of every pastor. As people learn to serve, they experience the joy of ministry and the church grows both qualitatively and quantitatively. God never intended the ministry to be done solely by one man or by a professional staff. Ministry is the right, the responsibility, and the privilege of every believer in God's family.

Robert slocum, in his book, Maximize Your Ministry, writes: "What kind of church will be effective in the next century? I am convinced the effective church for the twenty first century will be the church that mobilizes, equips, empowers, and supports ordinary Christians in ministry." 3

\section{The Priority of the pastor}

The word "pastor" is borrowed from animal husbandry, especially sheep raising. The pastor of a group of

'John F. MacArthur, Jr., The MacArthur New Testament Commentary: Ephesians (Chicago: Moody Press, 1986), 156.

${ }^{2}$ Gary Tangeman, The Disciple Making Church in the 21st Century (Fort Washington, PA: Christian Literature Crusade, 1996), 246 .

${ }^{3}$ Robert E. Slocum, Maximize Your Ministry (Colorado Springs, CO: NavPress, 1992), 8 . 
Christians is the person responsible under Jesus, who is the Master Shepherd, for teaching, feeding, developing unity, helping people in time of need, and doing whatever else is necessary to see that people continue in the faith and grow in their spiritual lives. ${ }^{1}$

In Eph 4:11-12, Paul says the heart of ministry is "equipping the saints for the work of service." The word "equip" means to make complete, to supply what is lacking. In secular Greek it was the word used of fishermen mending their nets. It was also used in the medical profession to denote or depict a doctor setting a broken bone. The idea was to make something usable, to restore it, to make it complete, or in the spiritual realm, to bring to maturity.

The Bible mentions several areas in which believers need to be equipped. First of all, we need to be equipped in order to do good works. "All scripture is inspired by God and is profitable for teaching, for reproof, for correction, for training in righteousness; that the man of God may be adequate, equipped for every good work" (2 Tim $3: 16-17)$. The Bible was given in order to prepare God's people to be able to do good works. Jesus said in Matt 5:16, "Let your light shine before men in such a way that they may see your good works, and glorify your Father who is in heaven."

\footnotetext{
${ }^{1}$ Tangeman, 222.
} 
Equipping also plays an important role in the restoration process. In Gal 6:1, Paul talks about what to do with a person who has fallen into sin: "Brethren, even if a man is caught in any trespass, you who are spiritual, restore such a one in a spirit of gentleness; looking to yourselves, lest you too be tempted."

The word "restore" is the same Greek word meaning "to equip" in Eph 4:12. To equip, in this setting, involves helping a sinning brother or sister, in a spirit of meekness and humility, to understand the error of their ways, to repent of their sin, and to come back into fellowship with God.

The Bible also reveals that equipping is needed for the strengthening of our faith. "For what thanks can we render to God for you in return for all the joy with which we rejoice before our God on your account, as we night and day keep praying most earnestly that we may see your face, and may complete what is lacking in your faith?" (1 Thess 3:910). Here was a group of brand-new believers in Christ. Paul was praying that God would give him the opportunity to "complete" (once again, our same Greek word for equipping) what was lacking in their faith. Because they were new believers, they were still weak in the ability to live in faith, trust, and confidence before God.

Another area where equipping is needed is in doing God's will. We need to be shown how to live lives that are 
pleasing to God. We need to be taught from the scriptures how to carry out God's will in every facet of life. "Now the God of peace, who brought up from the dead the great Shepherd of the sheep through the blood of the eternal covenant, even Jesus our Lord, equip you in every good thing to do His will, working in us that which is pleasing in His sight, through Jesus Christ, to whom be the glory forever and ever. Amen" (Heb 13:20-21).

Equipping is also important for unity. "Now I exhort you, brethren, by the name of our Lord Jesus Christ, that you all agree, and there be no divisions among you, but you be made complete in the same mind and in the same judgment" (1 $\operatorname{Cor} 1: 10)$.

God's word teaches us how to be open and transparent about ourselves. That allows others to say in kindness and love what needs to be said to help us and to make us more effective. When believers are properly equipped in this area, they know how to disagree without being disagreeable, and become skilled in "speaking the truth in love". (Eph $4: 15)$.

Equipping is also essential in helping believers develop a greater manifestation of Christlikeness in their lives. "A pupil is not above his teacher; but everyone, after he has been fully trained, will be like his teacher" (Luke 6:40). Through the systematic teaching and 
application of God's word to one's life, a person becomes more and more like Jesus Christ.

The key to a pastor's equipping ministry is the word of God. That is why Paul said to Timothy, "Until I come, give attention to the public reading of scripture, to exhortation and teaching" (1 Tim 4:13). When it comes to handling the Word of God, a pastor must do three things: he/she must read the Word, explain the word so that people understand what it says (teaching), and he/she must apply the word so that people are encouraged to do something with what they have learned (exhortation).

Finally, Eph 4:12 says that believers must be equipped for ministry. This part of a pastor's equipping responsibility requires not only the teaching of God's Word, but also the training of people for ministry. While in teaching the emphasis is primarily upon the imparting of information for the purpose of application, in training the emphasis is upon the imparting of a skill or ability for the purpose of ministry. In teaching, people understand what they need to do; in training; they learn how to do it.

In order for a pastor to equip people for the work of ministry, he/she must be willing to share his/her ministry with others. ${ }^{1}$

1'Tangeman, $222-225$. 


\section{Pastor as Teacher/Educator}

In addition to the role of equipper, the pastor also has the responsibility to teach or educate. Richard Armstrong says, "All pastors are teachers. Some may function primarily as preachers, or counselors, or youth ministers, or administrators, but whatever their role, teaching will always be a preeminent part of their ministry." 1

As the pastor teaches the members the importance of developing their ministry, there will be a mutual respect and appreciation between pastor and laity. "Just as soon as a church is organized, let the minister set the members at work. . . Let the minister devote more of his time to educating than to preaching. Let him teach the people."2

In the empowering and equipping process, God enters into a relationship with men and women, who in turn share this relationship with their fellow human beings.

It is reasonable to suggest that the pastor is the main person responsible for educating the church members about their role in fulfilling the mission of the church. James Garlow states:

Lay training or lay formation is far more interactional than that. At the core of lay training are two presuppositions: first, that the people of God

${ }^{1}$ Richard Stoll Armstrong; The Pastor-Evangelist in the Parish (Louisville, KY: Westminster/John Knox Press, 1990), 113 .

${ }^{2}$ White, Testimonies for the Church, 7:18-20. 
exist for service for which they need training; and second, that those who train them are their servants, not their masters. When we talk about lay ministry training, we are not talking about lay ministry training, we are not talking about persons who desire to lord their knowledge over those who do not know. Rather, we are talking about laypersons who want to be all God would have them to be and who need "enablers" or "equippers." These enablers are usually pastors who can help them understand their call to ministry, discover their gifts for ministry, learn how to select that ministry, and provide some kind of training for that ministry. ${ }^{1}$

Ellen white emphasized: "The work of the minister is not complete if he does not educate the souls newly come to the faith to be laborers together with God."2 She further stated:

Christ intends that His ministers shall be educators of the church in gospel work. They are to teach the people how to seek and save the lost. But is this the work they are doing? Alas, how many are toiling to fan the spark of life in a church that is ready to die!. How many churches are tended like sick lambs by those who ought to be seeking for the lost sheep! And all the time millions upon millions without Christ are perishing. ${ }^{3}$

Ellen white underlined that the educating work of the pastor is even more important than his or her preaching role, saying, "Let the minister devote more of his time to educating than to preaching. Let him teach the people how to give to others the knowledge they have received."

${ }^{1}$ James L. Garlow, Partners in Ministry: Laity and Pastors Working Together (Kansas City, MO: Beacon Hill Press, 1981), 105-106.

${ }^{2}$ White, MS 48, March 29, 1899, Ellen G. White Research Center, Andrews University, Berrien Springs, MI.

${ }^{3}$ White, The Desire of Ages, 825 . 
If lay education is to be successful, the pastor needs to focus on the element of training in the development of spiritual gifts. Eph 4:11, 12 emphasizes preparing and educating members for ministry. The pastor as educator has the sacred responsibility to enable members to develop their giftedness, thereby sharpening their skills and talents. As the pastor works with laypeople--the Bible's doctrine of the priesthood of all believers--the pastor will be able to see the potential of the laity as fellow ministers called to serve by God.

On the concept of lay ministry, Rex Edwards states that "the problem is that although so widely accepted, many of these concepts about lay ministry have little impact on the typical church member." 1 He further says, "Perhaps the greatest problem for that member of the church who tries to understand ministry is how the concepts can actually be applied in his or her life."2

Spiritual gifts are given to members for ministry, and pastors need to educate, equip, and empower members to use their gifts. It has already been noted that no one person or group is able to perform all the ministries of the church, and that when pastors and laity are properly educated about Paul's teaching of the church as the body

${ }^{1}$ Rex D. Edwards, Every Believer a Minister (Silver Spring, MD: General Conference of Seventh-day Adventists, 1995), 84 .

${ }^{2}$ Ibid. 
fitly joined together (Eph 4:16), the distinction between the clergy and the laity will disappear. Every member is unique and has a distinctive role to perform in ministry. Edwards further comments: "So one way to identify and fulfill one's ministry is to identify one's own uniqueness-what one likes to do, what one sees in the world, what one can offer. Then begin looking for situations in which to make that offer."1 If this type of education can be practiced in ministry, then the mission of the church will be fulfilled.

As an educator, the pastor has a privileged responsibility to empower the laity. The greatest help that can be given our people is to teach them to work for God, and to depend on Him, not on the pastor.

The pastor as teacher is responsible for the church's growth in ministry. First, the pastor is responsible because of his/her Christian stewardship and, second, by virtue of his/her office. The laity looks to the pastor as teacher. His/Her excellence in equipping and empowering puts him/her in the position to enlist the church members in a ministry that fulfills their Christian stewardship.

As White states: "Every effective lay minister depends upon the training and encouragement provided by his/her pastor. Ministry of the laity is not some reactionary, anticlergy movement. It is, in contrast to

\footnotetext{
${ }^{1}$ Ibid., 87.
} 
that, a movement to bring laypersons into a closer working relationship with their pastors!"1

The pastor, in educating the church members, plays a vital role in leading them into a right relationship with God and their fellow believers. Russell Burrill asserts that the educating role of the pastor has two purposes: the accomplishment of the purpose of the church and the fulfillment of the spiritual growth of each member. ${ }^{2}$

\section{Pastor as Discipler}

Most pastors see themselves functioning as equippers of the saints for ministry (Eph $4: 12$ ). ${ }^{3}$ Teaching and training are part of that task. Yet discipling involves more than just equipping. "Equipping is preparing people for tasks; discipling is relating people to Jesus. We are not just equipping people to work in the church; we are making disciples of Christ." ${ }^{4}$ The pastor's role as discipler seeks to bring people into that totally dependent, intimate personal relationship with Jesus Christ. Since such a relationship is only possible by the power of the Holy

${ }^{1}$ Ibid. , 109.

${ }^{2}$ Russell Burrill, Class notes, CHMN615 Evangelism and Church Growth, Andrews University, Berrien Springs, MI, 1999, $1-3$.

\footnotetext{
${ }^{3}$ Armstrong, 143.

${ }^{4}$ Ibid.
} 
Spirit (John 6:44, 65; Rom 8:9, 16-17; 1 Cor 12:3), the pastor's role as discipler is instrumental. ${ }^{1}$

Claiming people as disciples is Christ's work; challenging and training people to be Christ's disciples is the work of the pastor. Trainers equip people for tasks; disciplers equip people to disciple other people. The role of the discipler must include equipping others to do the work of evangelism. The pastor's task as discipler is to help people to discover, celebrate, develop, and employ their gifts in the church's evangelistic ministry. However, the pastor's evangelistic task as discipler is not limited to helping people discover their gifts and training them to be evangelistic persons. There is the equally important task of discipling the members to be faithful witnesses of Jesus Christ. All are not evangelists or pastors. However, every Christian is a witness for Christ. One of the discipler's roles is to assist people in discovering and communicating the ways by which God has been at work in their lives.

As the pastor equips and empowers the church members to experience discipleship, the people will be challenged to put God first in their giving (Prov 3:9; Matt 6:33), to give in proportion to their means (Gen 28:22; 2 Cor 8:3), to give sacrificially (2 Sam 24:24; Mark 12:41-44), and to give systematically (Num 28:12; 1 Cor 16:1-2). The discipling

\footnotetext{
${ }^{1}$ Ibid. , 145 .
} 
pastor will constantly remind people that they are accountable to God for their stewardship. The most effective method of teaching the laity is by example.

What makes the disciple-making pastor different? In the broadest sense, he/she has committed time and resources to the job of making disciples who can do ministry. On the other hand, the generic pastor has committed time and resources to doing ministry rather than reproducing it.

Three distinctives make the disciple-making pastor stand out from the rest: his/her understanding, his/her commitment, and his/her practices. The disciple-making pastor understands the big picture. He/she is a kingdom thinker, which is much broader in scope than a mere localchurch thinker. The local-church thinker says, "We are building a great church." The kingdom thinker says, "We are taking the rule of Christ to the world." The local-church thinker says, "What you are in the church is most important." The kingdom thinker says, "What you are in the world for Christ is most important."

Disciple-making pastors see the Great Commission as imperative to "make disciples" as the methodology for reaching the world. The disciple-making pastor spends the majority of his/her time with those willing to be trained to reproduce themselves, who share the dream of the kingdom, who have the commitment of the cross, and who believe in 
multiplication as the commissioned methodology to reach the world.

The disciple-making pastor has four commitments:

1. He/She is committed to placing disciple making at the heart of the church.

2. He/She commits him/herself to the clear identification and communication of the roles of the pastor, the people, and the discipling process.

3. He/She is committed to the priesthood of all believers.

4. He/She has a commitment to multiplication. ${ }^{1}$

One can identify the disciple-making pastor by his/her practices. A disciple-making pastor:

1. Practices the principle of selectivity, which is the process of applying scriptural qualifications to the selection of leaders. Selectivity also means the intentional training and preparation of people to assume leadership roles.

2. Teaches and practices philosophical purity at the leadership level. Philosophical purity is agreement among leaders concerning the goal or product of the church. It is essential for long-term effective ministry. It is also vital to the multiplication of ministry, in particular the planting of good churches.

${ }^{1}$ Bill Hull, The Disciple Making Pastor (Old Tappan, NJ: Fleming H. Revell, 1988), 117. 
3. Believes in and practices accountability. Accountability is necessary because (a) it is a means for quality control; (b) it facilitates leadership; (c) it protects the congregation; (d) it makes ministry a joy; and (e) it helps people keep their commitments to God.

4. Effectively uses the small group for disciple making. The small group is the most effective vehicle that exists for full-orbed disciple making. According to Bill Hull :

a. The small group is Jesus' example. Jesus demonstrated the superiority of the small group for training. At different times and phases of His ministry, Jesus' followers were numbered as five hundred, 120, seventy, and the twelve. But when it came to training, Jesus chose the small group as His primary vehicle.

b. The small group provides the proper ministry flow. It allows the cream to rise to the top. The flow of people is like pouring the entire group into the top of the funnel. Only a select few make it through the filtering process of the small group. Those who make it through are prime candidates for leadership.

c. The small group provides a controlied environment. Teaching, a person to obey requires some ability on the part of the teacher to control the 
learning environment. For disciple making, nothing beats the small group. It possesses all the necessary ingredients to fully teach people to make disciples. 5. Believes in and practices the decentralization of pastoral care. Decentralization of pastoral care is essential for two reasons:

a. The proper use of the pastor. The pastor is primarily a trainer of people. In addition to the many pastoral functions, his/her main task is to train people to do ministry. If the church insists that the pastor prepare people for ministry, ministers will be equipped and the quality of work will be high. The pastor's work is to declare the what and why of ministry, then to train all willing members to do that work. After that, he/she must manage the ministry. b. The proper use of the body. The goal of the decentralization of ministry is the grand picture of Eph 4:16--every member doing his part, pulling together for the purpose of God. The picture also teaches that the people will be fulfilled, productive, and the body will grow and build itself. This is the most loving thing a pastor can do for the church.

The proper use of the body can be achieved. Remember that the pastor's job is to declare the vision and inspire people to ministry. The disciple-making pastor commits him/herself to the decentralization of pastoral care because 
it is the right thing to do. Under the guidance of Paul's pastoral model, the pastor finds his/her desired goal and the corporate body becomes mature and effective. The disciple-making pastor is left with no choice; he/she must by nature take the church in this fulfilling direction. ${ }^{1}$

\section{Pastor as Trainer}

The pastor should first understand that his/her responsibility to train members is for the sake of their ministry and not necessarily for his/her ministry. It is true that in the process the pastor's ministry will be enriched. Ellen white states: "Every church should be a training school for Christian workers. Its members should be taught how to give the Bible readings, how to conduct and teach Sabbath-school classes, how best to help the poor and to care for the sick, how to work for the unconverted."2

Russell Burrill also says, "Training is an absolutely vital component that will require significant pastoral attention if people are to function effectively in ministry." ${ }^{3}$ When the pastor neglects the training function, the church becomes spiritually weak. ${ }^{4}$ Burrill states, "The best remedy for Laodicea is for pastors to train members and

\footnotetext{
${ }^{1} \mathrm{Hull}, 104-189$.

${ }^{2}$ White, The Ministry of Healing, 149.

${ }^{3}$ Burrill, Revolution in the Church, 107.

${ }^{4}$ Ibid. , 49 .
} 
put them into meaningful ministry in harmony with their spiritual gifts."1

Indeed, "motivating and equipping volunteers in the church demands great amounts of time and energy" ${ }^{2}$. which is similar to the experience of Jesus, who trained His disciples for three and one half years. The pastor must see him/herself as pivotal in the training and equipping process of the members for the development of their ministry.

\section{Pastor as Administrator}

The role of administration is a vital aspect of an empowering ministry. The Bible provides a solid base for affirming the indispensable role of administration in the effective fulfillment of the mission of God's people. Except for the wise advice of his father-in-law, Jethro, Moses would probably have burned himself out in a hurry. He was trying to do everything all by himself. Jethro urged the harried leader to appoint rulers of thousands, hundreds, fifties, and tens to share the administrative burden. The rulers judged the people at all times, bringing only the hard cases to Moses (Exod 18:13-27). When this principle of delegating responsibility with commensurate authority was put into practice, Moses became a much more efficient administrator.

\footnotetext{
${ }^{1}$ Ibid. , 52 .

${ }^{2}$ Holmes and Kilcher, 107.
} 
Although churches in New Testament times did not have to deal with the complexities of church administration as we understand them today, they did many things that would fall under that category, such as choosing officers (Acts 14:23) and delegates (Acts 15:22), raising money ( 2 Cor 8 and 9), receiving new members (Acts 11:24), sending out missionaries (Acts 13:2-3), supporting mission causes (Acts 11:29-30; 1 Cor 16:1-3), disciplining members (2 Cor 13:1-2), settling disputes (Acts 15:1-21), and even drafting policy statements (Acts $15: 22-29) .^{1}$

"Church administration," as commonly understood today, would involve the pastor in a host of particular responsibilities, of which the following are examples.

1. Carrying out the numerous plans and programs in the life of the congregation with the efficiency of a skilled executive

2. Attending many meetings outside the congregation, connected with denominational and community affairs

3. Assuring the financial success of the church, including building funds and denominational assessments, as well as the local budget

4. Maintaining a favorable public relations response within the congregation and community, both to the church as an institution and to himself as a leader

${ }^{1}$ Armstrong, $175-176$. 
5. Running an efficient office with prompt correspondence, accurate records and statistics, prompt reports to superiors, frequent mailings, and an efficiently managed staff

6. Securing the right leadership to move any program rapidly and smoothly

7. Functioning as a personnel expert in "handling opposition" within the congregation so that it neither slows down the program nor "harms the church."1

As one examines the many roles of the pastor, he/she cannot take the responsibility of pastoral administration merely from a programatic perspective. The pastor should understand that church administration ought to be peoplecentered. Administration is an ability to work with and through people to accomplish the mission of the church.

Definition of Church Administration

For one to fully understand and appreciate the role of the pastor in empowering and equipping the laity as an administrator, it is important to define church administration.

A discussion of church administration should begin with an understanding of administration. "Administer" is derived from the Latin administrate, meaning literally "to serve." 2

${ }^{1}$ Alvin J. Lindgren, Foundations for Purposeful Church Administration. (Nashville: Abingdon Press, 1965), 17-18.

I'Ibid., 22 . 
Arthur Adams states:

The English word developed from the Latin verb meaning "to serve." The major Biblical word is a term that means "servant" or "waiter." It is most often translated "minister" and has come into our language as "deacon." Jesus uses the term when he says, "The Son of man came not to be ministered unto, but to minister." It appears in the sense of administer in Paul's letters.'

What, then, is church administration? Charles A.

Tidwell defines church administration as follows:

Church administration is the leadership which equips the church to be the church and to do the work of the church. It is the guidance provided by church leaders as they guide the church to use its spiritual, human, physical, and financial resources to move the church toward reaching its objectives and fulfilling its avowed purpose. It is enabling the children of God who comprise the church to become and to do what they can become and do, by God's Grace. ${ }^{2}$

Peter Wagner defines church administration in the

following manner:

The gift of administration is the special ability that God gives to certain members of the Body of Christ to understand clearly the immediate and long-range goals of a particular unit of the Body of Christ, and to devise and execute effective plans for the accomplishment of those goals. ${ }^{3}$

Church administration involves equipping and guiding the church members to reach their potential by using their giftedness. This would include their human., spiritual,

${ }^{1}$ Arthur M. Adams, Pastoral Administration

(Philadelphia: Westminster Press, 1964), 13.

${ }^{2}$ Charles A. Tidwell, Church Administration: Effective Leadership for Ministry (Nashville: Broadman Press, 1985), 27 .

${ }^{3}$ Wagner, Leading Your Church to Growth, 88-89. 
physical, and financial resources. "The administrator must plan, organize, find and train leaders and workers, offer some guidance, and encourage discipline. . . . Someone must be engaged in administration if a group is to do anything together."1

Like other aspects of his/her work, the administrative role of the pastor does have some challenges. Pastors engage in administration and organization in almost every area of their ministry. They exercise such abilities in relation to the church members, school boards, and other church departmental committees. W. T. Purkiser points out that effective coordination of the activities of people demands organization. And organization requires administration. Any possible grouping of persons in pursuit of common objectives must have structure. ${ }^{2}$

The success of the pastor as an administrator is dependent to a great extent on how he/she perceives the ministry of the laity. If the church is viewed merely as an institution, then empowering and equipping the laity would be seen as a support system to his/her ministry. If, on the other hand, the church is viewed as a community, then the ministry of the laity would be seen as belonging to the church. As a result, the pastor/administrator will see

${ }^{1}$ Adams, 14.

${ }^{2} \mathrm{~W}$. T. Purkiser, The New Testament Image of the Ministry (Grand Rapids, MI: Baker Book House, 1970), 125. 
him/herself as one minister among other ministers. The only advantage will be his/her special skills and training. The skills, talents, and giftedness of the laity will be appreciated as beneficial to the church's ministry. John Fowler writes:

The very fact that the church is a community, working together toward common objectives, demands organization and expert administration. The church as institution does not exist as an entity apart from the church as community. The institution is a vital support for the church as community. The purpose of administration, then, is to coordinate all the church's resources, to create an atmosphere in which the Holy spirit can establish the spiritual kingdom of heaven. ${ }^{1}$

The Seventh-day Adventist Manual for Ministers emphasizes the pastor's administrative role very clearly: "The pastor should be the spiritual leader and adviser of the church, and should instruct the church officers in their duties, give counsel on carrying them out, and help them plan for all branches of church work and activity."2 John Fowler states that "administration relates primarily to people. The pastor's skill in his human relationships determines his success in pastoral administration."3

Church administration is concerned both with people and programs. However, the difference between successful or

'John Fowler, Adventist Pastoral Ministry (Boise, ID: Pacific Press Pub. Assn., 1990), 96-97.

${ }^{2}$ Manual for Ministers (Washington, DC: The Ministerial Association, General Conference of Seventh-day Adventists, 1977), 44 .

${ }^{3}$ Fowler, 100 . 
non-successful administration depends on the emphasis the pastor/administrator places on people as compared to programs. Tidwell emphasizes:

Church administration truly is an equipping ministry. As church leaders understand, accept, and practice this concept of ministry, the church will be mobilized, its resources liberated, and the work of the church will be accomplished in almost unprecedented effectiveness. ${ }^{1}$

One of the challenges of the pastor is the administrative role of ministry. Most pastors, unfortunately, have received very little training in church administration during their formal education. Whether or not pastors accept the administrative role as part of ministry, it is critical for them to do so in order to be successful in today's society. The pastor should view administration as a complementary facet of ministry, despite the challenges. Yet many pastors resent administration. Lindgren states:

The ministers' own evaluation of their work indicated that 40 percent of their time was given to administrative work and 10 percent more to organizational activities, half their time thus being consumed in organizational responsibilities. More important, however, is the fact that these ministers generally resented growing demands upon their time. They felt that they had been called primarily to preach, teach, and do pastoral work, tasks which received a decreasing share of their working time. ${ }^{2}$

\footnotetext{
${ }^{1}$ Tidwell, 44.

${ }^{2}$ Lindgren, 15-16.
} 
Administration is not just another aspect of ministry, but an integral part of the pastor's role in the area of empowering and equipping the laity. Norton says:

Ministerial leadership has three essential ingredients: (1) emancipation--the equipping of church members according to gifts so they do not rely totally on the pastor for operation, (2) dissemination--the proclamation of the gospel and expansion into new communities, (3) administration--the planning and implementation of goals to accomplish the church mission.'

\section{Principles of Administrative Leadership}

The behavioral sciences have identified several

principles as keys to good leadership. The first is consensus. People interact best when they agree on their objectives. We call this goal ownership. "If the majority identify with the goals, the group will interact effectively to achieve them. . . Thus the development of a consensus regarding what the church should do and how it is to be done is the first step in building confidence, trust, and the positive interaction needed to achieve the church's goals."

The second leadership principle is delegation. Trusting relationships are necessary in order to safely delegate responsibility. When responsibility is delegated to, and accepted by, every member of the church, the church becomes a dynamic and powerful organization. Delegation

\footnotetext{
${ }^{1}$ Ricardo Norton, Class notes for CHMN638 Seminar in Leadership, Andrews University, Berrien Springs, MI, autumn 1998.
} 
develops motivation in the grass roots, enlisting the willing support of a large majority within the church.

The third principle is the development of the human resources of the church. Our greatest failure may be that we place responsibility on people without training and equipping them. If a person is committed to a particular task and has the gifts and skills to perform it, he/she will generally be highly motivated and effective in his/her work. That is why Ellen white says that the pastor's work in training the laity is even more important than his/her preaching. The church must provide the training needed by each member involved in church activities. Only then will the members of the body of Christ begin to interact in a satisfying and productive way.

The fourth principle is accountability. People must interface, not only in a satisfying and trusting way, but also in a responsible way. If God's spiritual kingdom is to be realized in the church, there must be clear-cut goals, correct principles, and adequate guidelines against which to evaluate relationships and the behavior of individuals and groups. Confidence and trust demand a high level of responsibility on the part of those involved. An information system that provides frequent feedback is essential to accountability.

Finally, there must be rewards. While we cannot reward laymen or paid workers with higher wages or promotion as do 
secular organizations, we can provide them with the greatest rewards possible in this life. A few of these rewards are: the continual growth and development of their spiritual gifts; a satisfying and fruitful ministry; harmonious relationships with others; a sense of achievement in helping to bring unity of action to the body of Christ; the achievement of goals individually and collectively; and the continual advancement of God's Kingdom.'

Pastors as church administrators, therefore, are to be faithful stewards of all that has been entrusted to them, including the temporal affairs of the church and the spiritual welfare of the people. What is required of stewards is trustworthiness. In short, faitheul pastoral administration is characterized by trustworthy management and servant leadership. ${ }^{2}$

The pastor/administrator has the responsibility to motivate, equip, and empower church members with the proper knowledge, tools, and skills in such a manner that there will be growth and fulfillment of mission both to the members individually and the church as the body of christ. Church administration is a dynamic experience and interaction of persons, of which no two are the same. Lindgren states:

Purposeful church administration is the involvement of the church in the discovery of her nature and mission and in moving in a coherent and comprehensive manner toward providing such experiences as will enable the church to.utilize all her resources and personnel in

${ }^{1}$ Fowler, 101-103.

${ }^{2}$ Armstrong, 177 . 
the fulfillment of her mission of making known God's love for all men.'

This definition of church administration has within it three distinct elements that need to be identified clearly.

(1). The overarching concern of church administration is the fulfillment of purpose, to "let the church be the church."

(2) This definition of church administration is comprehensive, viewing the administrative task as concerned with every aspect of church life and seeking to coordinate every experience toward one unified purpose. Administration cannot be confined to the organization, program, and promotional aspects of church life. Each activity is to be an avenue of ministering to the needs of persons, as those needs are defined by the gospel.

(3) Finally, this definition involves all members of the church in administrative responsibilities.

Administration is not the concern only of the pastor and few "key" laymen and laywomen. The whole congregation must understand the nature and mission of the church and must be involved individually and corporately in making known God's love, so that the congregation can fulfill its mission. ${ }^{2}$

The nature of the church is such that any valid approach to church administration must rest on a Godcentered, person-oriented polarity principle. To be Godcentered is to acknowledge God as the source and life of the church's mission. To be people-oriented is to recognize that "God so loved the world" that He sent His own son to make known His love for all men. The church is, therefore, not primarily a concept or an institution, but a ministry to persons.

\footnotetext{
${ }^{1}$ Lindgren, 60 .

${ }^{2}$ Ibid., 60, 61 .
} 
The church administrator is not to conceive his/her role as that of serving the institution of the church, but rather he/she is to train and lead the church in serving the community and the world. ${ }^{1}$

\section{Administrators' Gifts and Their Effects}

Based on a spiritual inventory workshop in the

Antillian Union, C. Dionisio Christian says:

When we scored the administrators' sample group gifts according to their answers to The Spiritual Gifts Inventory, we found that those holding administrative offices were many who had as their highest scoring gifts the gift of Pastoring. Some had the gift of Apostleship, others the gift of Faith, followed by the gift of Administration and Teaching. Thus the following "probable 'gift cluster'" found among the administrators was:
1. Pastoring
2. Apostleship
3. Faith
4. Administration
5. Teaching ${ }^{2}$

He further classifies administrators into five categories indicating the effects and characteristics of each category.

1. Those administrators with the gift of pastoring were very concerned regarding their knowledge of truth, doctrine, and the teachings of the recent movements in

IIbid. , 61, 62, 64 .

${ }^{2} \mathrm{C}$. Dionisio Christian, "Developing and Implementing a Program of Instruction for Church Administrators and Ministers of the Antillian Union Conference of Seventh-day Adventists to Enlarge Their Understanding of the Doctrine of Spiritual. Gifts as It Relates to Their Roles and Functions" (D.Min. dissertation, Andrews University, 1984), 57-58. 
relation to the Seventh-day Adventist interpretation of the sanctuary, the Spirit of Prophecy, and other issues among the workers of their field.

2. The administrators with the gift of apostleship proved to be very concerned with having the gospel taken to and established in new places.

3. The administrators with the gift of faith have proven to be people with extraordinary confidence in the will and purpose of God for the future.

4. The gift of administration was one of the gifts on which many of the administrators scored the highest. Those administrators with the gift of administrators usually excelled in comparison with their colleagues who had gifts other than this one, in that the activities in their field of duty were running successfully and smoothly. They were effective in having those "under" them take care of the smaller details of their big plans. Those with this gift were able to rally around those who worked with them and were also willing to serve. They were looked upon as leaders. They organized and planned for the growth of the church. This special group is needed in the church today to solve problems and to make decisions for the growth of the church. We need more of this God-given gift among us.

5. The administrators with the gift of teaching were noticeably ready to apply a practical lesson or a scripture lesson in their activities, and their listeners easily 
grasped or learned what to communicate. It was observed that this type of administrator is rather strong and effective if his gift of teaching is in a "gift cluster" with the gift of administration, the gift of apostleship, and/or the gift of leadership. ${ }^{1}$

In Christian's evaluation, it was found out that, although some administrators may have an intuitive understanding of spiritual gifts and might be quite effective, the administrators with a poor knowledge of understanding of spiritual gifts

1. tended not to know what to expect from themselves as administrators or from their colleagues

2. are somewhat harsh, ruler-type administrators

3. are very often ineffective when they address their workers

4. generally have a poor relationship with the laity

5. have difficulties in addressing problems effectively

6. make real church growth very difficult

7. are usually less effective in their approach to the mission of their fields. ${ }^{2}$

From the above results, one should note that, although the pastor has the administrative gift, for him/her to

\footnotetext{
IIbid. , 58-63.

'Ibid. , 63-64.
} 
empower and equip the laity effectively, he/she must have a clear understanding of spiritual gifts.

There are four important factors that should govern pastors/administrators as they use their spiritual gifts for empowering and equipping the laity.

1. The importance of understanding the doctrine of spiritual gifts

2. The identification of their own gifts

3. The understanding of how these gifts affect their effectiveness, success, or failure in the fulfillment of their roles and functions

4. They have to see that it is their obligation to share with other workers and the laity what they themselves have learned and experienced. ${ }^{1}$

As a result of properly utilizing these factors, pastors would be better able to discover and develop their administrative abilities, as well as those of the laity, thereby enabling the laity to fulfill the mission and ministry of the church.

Ibid., $71-72$. 
CHAPTER 3

CHURCH MINISTRY PROGRAMS IN THE

SOUTH CARIBBEAN CONFERENCE

\section{Adventism in Trinidad and Tobago}

The South Caribbean Conference of Seventh-day

Adventists includes the islands of Trinidad and Tobago, a unitary state located in the southeastern part of the Caribbean. Trinidad is the most southerly of the chain of islands stretching from Florida in the United States of America to Venezuela in South America and enclosing the Caribbean sea. The island is 11 kilometers off the coast of Venezuela, and is separated from Venezuela by the Gulf of Paria. Tobago is situated 30 kilometers to the northeast of Trinidad.

Seventh-day Adventism in Trinidad and Tobago started in 1891, when William Arnold, an American colporteur, pioneered the Seventh-day Adventist literature ministry in Trinidad. ${ }^{1}$ Ninety years after the Seventh-day Adventist literature ministry started in Trinidad, and seventy-five years after the South Caribbean Conference was organized with its

\footnotetext{
${ }^{1}$ Eric John Murray, A History of the Seventh-day Adventist Church in Trinidad and Tobago, 1891-1981

(Trinidad, West Indies: The College Press, 1982), 17.
} 
conference office in Port of Spain, the Seventh-day Adventist Church in Trinidad and Tobago had reached a membership of 22,670 , distributed among 124 churches and companies. The figures for each island are shown in table 1 .

TABLE 1

MEMBERSHIP DATA FOR TRINIDAD AND TOBAGO

\begin{tabular}{lcr}
\hline Island & Churches and & Membership \\
\hline & 102 & 19,565 \\
Trinidad & 21 & 3,105 \\
Tobago & & \\
\hline
\end{tabular}

The 375-member South Caribbean Conference, which in 1906 boasted two departments, three ministers, and a fourmember executive committee, had become in 1981 an organization that employed 334 workers to care for the needs of a growing constituency. Growth was exponential. Between 1894 and 1931 the membership grew from 6 members to 3,400. During the next fifteen years, the membership increased to 6,816. By January 1, 1975, the South Caribbean Conference had a membership of $16,983 .{ }^{1}$ In 1984 , the membership was

I'Ibid., 20, 69, 138, 139. 
$24,837 i^{1}$ by 2001 , it was $54,159 .^{2}$

Although the Seventh-day Adventist membership in the South Caribbean Conference is more than 54,000, the church is faced with many challenges. Among the more serious challenges are multiculturalism and religious pluralism. Demographic trends in that culture indicate that these challenges will continue to increase.

The population of the country consists of as many as thirteen ethnic groups of which two form the majority. The African-Caribbeans account for approximately 41 percent of the population and the East Indians account for approximately 41 percent.

The dominant religious communities claim Christianity as their religious preference. They account for 70 percent of the population. Catholicism represents the largest Christian community, and 13 percent are Protestants. Other religious communities include Hindus, which account for 23 percent, and Muslims, 6 percent of the population. Thus, the empowering and equipping of the laity for ministry cannot be unmindful of these challenges and their influences.

The term multiculturalism refers to social arrangements characterized by cultural diversity. In practice, this

${ }^{1}$ Seventh-day Adventist Yearbook (Hagerstown, MD: Review and Herald Pub. Assn., 1984), 172.

${ }^{2}$ Seventh-day Adventist Yearbook (Hagerstown, MD: Review and Herald, 2001), 133. 
means non-trivial interpersonal contact between individuals and groups who differ in their ethnicity. ${ }^{1}$

Religious pluralism is a special challenge facing the world religions today, yet in another sense religious pluralism has always been with us. As the history of religions shows, each religion arose in a religiously plural environment and shaped itself in reaction to that pluralism. ${ }^{2}$

The Seventh-day Adventist Church in the South Caribbean Conference must be conscious of these critical issues if pastors are to empower and equip the laity effectively for ministry. Since the topics of multiculturalism and religious pluralism are beyond the scope of this dissertation, I shall limit my study to strategies to empower and equip the laity to evangelize two religious communities, namely Hindus and Muslims.

\section{Strategy Proposal}

1. Equip the laity to understand and appreciate cultural diversity. Such equipping will include a Cultural Diversity Seminar, which will deal with the cultural and historical factors that impact on empowering the laity.

\footnotetext{
${ }^{1}$ Paul Pedersen, Multiculturalism as a Fourth Force (Castleton, NY: Hamilton Printing Company, 1999), 19.

${ }^{2}$ Thomas Dean, Religious Pluralism and Truth: Essays on Cross-Cultural Philosophy of Religion. (Albany, NY: State University Press, 1995), 45.
} 
2. Equip the laity to embrace the reality of the transcendence of Christ's grace to reach all cultures. Equipping will address ethnicity within the church and in the wider community. Aspects of culture, religion, family, education, and socio-economic values of the religious communities should be emphasized, so that evangelistic bridges will be established between the church and the wider community.

3. Equip the laity with a basic knowledge of some of the fundamental teachings of the different religious communities. Wynall F. Kerr states:

Whenever an attempt is made to compare two religions or denominations, the basis used is usually an analysis of their fundamental beliefs. Nevertheless, it is always a tedious task to justly analyze and classify these beliefs, since each part of a religion impacts on and informs all the others as well as the whole system. ${ }^{1}$

Religious seminars should be conducted by the South

Caribbean Conference to better empower and equip pastors and laity to evangelize the religious communities of Hindus and Muslims. Caribbean Union College should teach courses on cultural diversity so that church leaders will be more aware and hence be more sensitive to the challenges of the other religious communities.

Because of these challenges, there is a need for a pastoral model to empower and equip the laity. The

${ }^{1}$ Wynall F. Kerr, "A Proposal Strategy for Evangelizing the Hindus of the Republic of Trinidad and Tobago" (D.Min. dissertation, Andrews University, Berrien Springs, MI, 1989), 128 . 
Scriptures indicate that when the church is not fulfilling an evangelistic function in the world, it loses its true reason for existence. "You are the salt of the earth. But if the salt loses it saltiness, how can it be made salty again? It is no longer good for anything, except to be thrown out and trampled by men" (Matt 5:13). This concept of the mission of the church teaches that pastor and laity must be trained to evangelize.

\section{Overview of Church Ministry Programs}

The highlight of church ministry programs in the south Caribbean Conference is evangelism. Most of the evangelism is pastoral. The majority of the laity is not involved in ministry. During my early years in ministry, I concluded that it was important to empower and equip the laity. For the purpose of this study, I will analyze the equipping models of three churches in the South Caribbean Conference: (1) The Centralized Model, found at the Scarborough Seventh-day Adventist Church, Tobago; (2) The Small-Group Model, utilized by the Siparia Seventh-day Adventist Church, Trinidad; and (3) The Departmental Model, used by the Sangre Grande Seventh-day Adventist Church, Trinidad.

The Centralized Model

In this model, all departments report directly to a central staff member or leadership board. During the years 
1986-1988, the Scarborough Seventh-day Adventist Church started an equipping ministry program. A leader was selected to spearhead the ministry and to work with the senior pastor and church leaders. The leader worked with a team, the pastoral staff, and ministry leaders to (1) develop a central record-keeping system that coordinated information and facilitated the connection of members with ministries that utilized their gifts, (2) train ministry mentors who met with members to learn their needs and connected members to ministry opportunitie, (3) help coordinate church district programs, (4) conduct seminars for department heads and ministry leaders, placing them into ministry according to their giftedness, and (5) network with groups and organizations in the community to create opportunities for members to serve.

\section{Advantages of the Centralized Model}

1. A clear point of entry ensures that all members have the opportunity to serve and to be served.

2. The first emphasis is placed on the member as a child of God and second on placing the member in ministry.

3. Coordinated ministry descriptions enable the member to find the opportunity within the church that best suits his or her gifts and talents. 
4. A dedicated leader of the equipping ministry department ensures that program ministry needs will receive attention according to priority and need. ${ }^{1}$

\section{Disadvantages of the Centralized Model}

1. Substantial development time is required to initiate a full-scale program. Expectations need to be adjusted accordingly.

2. The potential for bureaucratic structures and bottlenecks is great.

3. The transition of members from being served by the department of equipping ministry to involvement in other departments and programs requires thoughtful coordination.

4. In the early stages the process may be confusing, as program ministry leaders and other staff members shift from independent recruitment activities to a centralized "human resource" department. ${ }^{2}$

The Small Group Model

The Siparia Seventh-day Adventist Church implemented a small-group equipping ministry during 1990-1993. The experience of community was a high priority for the church, which led the church to reorganize its church ministry program around small groups. The equipping ministry team

\footnotetext{
'Sue Mallory and Brad Smith, The Equipping Church Guidbeook (Grand Rapids, MI: Zondervan, 2001), 105.

${ }^{2}$ Ibid.
} 
utilized the existing small-group structures to help groups guide members to places of ministry. As a result, members were involved in community ministry, hospital ministry, prison ministry, prayer-cell ministry, Bible study ministry, visitation ministry, and church planting ministry.

These small groups provided an environment where members were nurtured, had their need for community met, and found support in their biblical and spiritual understanding of themselves. The small-group equipping ministry model is beneficial in a variety of ways:

1. Assimilation: People assimilate easily and make friends quickly in small groups.

2. Biblical Foundations: Small groups provide excellent places for interactive learning and personalized application of biblical truth.

3. Discovery: Small groups are considered by many to be the best place to conduct gift-assessment programs.

4. Matching: Matching people to ministry opportunities requires thoughtful attention to the unique needs of the individual. Many small-group leaders welcome assistance with this area of responsibility.

5. Placement and Growth: These features are clearly enhanced by the support a person receives in the small group. The equipping ministry team facilitates coordination between leaders of small groups and ministry areas. 
6. Recognition and Reflection: Leaders of the equipping ministry and the small group can ensure that people grow through ministry by providing reflection opportunities and celebration of service contributions. ${ }^{1}$

Small groups and equipping ministry can be a powerful combination. A healthy small-group program is an equipping ministry system, because the church is inviting, training, and placing gifted laypeople in small groups where they can exercise their gifts. Equipping ministry is enhanced in small-group clusters that facilitate community, support personal growth, and encourage people to serve. As group members help each other find a place of service, they can, from the beginning, focus on supporting each other rather than looking only for what they can get from the group. Mutual commitment is built around a particular and immediate task.

Disadvantages of the Small-Group Model

1. Many churches have discovered that once the group bonds, it is very difficult to integrate new people.

2. Inwardly focused groups often become discouraged or develop unhealthy relational patterns.

One alternative is to find ways the group can do service projects together. An even better alternative is to help members discover their gifts and serve in other areas,

${ }^{1}$ Ibid., 112. 
maintaining the small group as a place of support, ongoing learning, prayer, and encouragement. As individuals are focused on service in areas of giftedness outside the group, they report to the group the concerns of the church and community. ${ }^{1}$

The Departmental Model

During 1995-1998, the Sangre Grande Seventh-day Adventist Church developed the departmental model of ministry. This model involved training the leaders of each ministry department so that they developed skills in the equipping ministry system. Operating as equipping leaders for their responsibility areas, the department heads assumed responsibility for interviewing members, placing them in service according to their gifts and abilities, monitoring and supporting their ongoing involvement, and recognizing them for their ministry.

Some of the preparations to facilitate the program involved the following:

1. The department leaders were convened to lay the groundwork for the equipping ministry. The groundwork included the development of uniform ministry descriptions, coordinated training sessions, selection of gift-based ministry materials, and a system for recognition.

\footnotetext{
${ }^{1}$ Ibid., 113-114.
} 
2. A team of ministry personnel was formed to share departmental ministry needs and coordinate outreach programs. The ministry team provided a forum for sharing information about members who had unique gifts and talents.

3. Department heads and ministry coordinators were given training in equipping ministry.

4. Gift-based seminars were conducted by the pastoral staff and conference personnel to help members discover the gifts and connect their ministry to their spiritual growth. ${ }^{1}$

\section{Advantages of the Departmental Model}

1. The leaders who invite members to serve understand the needs of the department.

2. Members are mobilized for ministry according to their giftedness.

3. Department leaders conduct departmental orientation seminars.

4. Ministry is shared between the pastoral staff, ministry coordinators, and departmental leaders. ${ }^{2}$

\section{Disadvantages of the Departmental Model}

1. The focus of equipping ministry often shifts to meeting departmental staffing needs and not to developing members as disciples.

$$
\begin{aligned}
& { }^{1} \text { Ibid. } 108 . \\
& { }^{2} \text { Ibid. }
\end{aligned}
$$


2. Department leaders may underutilize members' gifts and skills.

3. The needs of the community may be neglected if church programs focus on inviting members to serve.

4. Lack of a centralized interviewing system results in multiple entry points for service, which may confuse new members and cause them to be poorly integrated into the total ministry of the church. ${ }^{1}$

\section{Ministry in Trinidad and Tobago}

As mentioned earlier, the highlight of church ministry programs in Trinidad and Tobago is evangelism. Hence, I will examine the following programs: (1) pastoral crusades and (2) lay crusades.

\section{Pastoral Crusades}

During my years in ministry, pastoral crusades were the high points of evangelism. Pastors who were evangelists conducted at least two crusades a year. Some pastors/evangelists were not able to empower and equip the members. This resulted in the following:

1. The laity was not equipped for the conservation of the new members.

2. The converts were considered the pastor's converts.

3. The pastors were responsible for membership conservation.

${ }^{1}$ Ibid. 
Pastors who were not evangelists felt challenged by their fellow ministers and the laity who had the gift of evangelism. Those pastors did one of the following:

1. They invited a pastor/evangelist to conduct a crusade.

2. They invited a pastor/evangelist to conduct a joint crusade.

3. They invited the conference evangelist to conduct a crusade.

4. They invited the laity to conduct a crusade(s).

5. They participated in conference crusades conducted by a guest evangelist.

\section{Lay Crusades}

During the years 1990-1998, churches in the south Caribbean Conference conducted at least one lay crusade and one pastoral crusade annually. The following were noted:

1. The church members were not always empowered and equipped to conduct lay crusades.

2. The members who were interested in public evangelism were involved in crusades.

3. The members who were interested in other aspects of ministry were not empowered and equipped in their areas of giftedness.

4. The reporting of baptisms was credited to the pastors, which discouraged the laity. 
5. Some pastors felt challenged by the ministry of the laity.

There was no program to empower and equip the laity. As a result, many members did not discover and utilize their giftedness. In the light of this, I propose that the south Caribbean Conference emphasize the concept of pastor and laity in ministry.

According to Edwin English: "The cultural environment of the church in the South Caribbean Conference, because of the diversity of religious backgrounds from which these people come, is the fact that the concept of the Ministry of the Laity is virtually unknown and obviously lacking." 1 The concept of the laos as held by many pastors in the south Caribbean Conference presupposes a distinction between the clergy and the laity.

Biblically, the church is laity (Acts 11:26; 12:15; 1 Cor 1:2; 1 Pet 2:9), and there is no structural difference between the clergy. and the laity. This clergy-laity concept pervades many churches, and is alive in certain areas of the work of ministry in the South Caribbean Conference. Because of this misconception, both ministers and members may have a wrong understanding of their mission to the world.

${ }^{1}$ Edwin A. English, "An Evaluation of the Concept and Function of Mutual Ministry and Spiritual Gifts in the South Caribbean Conference" (D.Min. dissertation, Andrews University, Berrien Springs, MI, 1974), 3. 
Most converts in the South Caribbean Conference come from religious traditions which made them dependent on the minister. This same notion has permeated the ministry in the South Caribbean Conference. Most ministers carry out independently every phase of the work of the church, in many cases irrespective of the talents and abilities of the members. ${ }^{1}$ As a result, most pastors do not empower and equip the laity.

Many of the pastoral crusades conducted between 19901998 did not involve the majority of the laity in the context of their giftedness. This created a challenge to the pastors, reflected in the low number of baptisms and the Iittle support given to the new converts. The lack of lay involvement. was further demonstrated in the membership conservation programs.

The pastoral crusades that were lay-oriented yielded more baptisms. The church members were supportive of the new converts, no doubt because the members played a role in leading the new converts to Christ. Subsequently, the retention of new converts was high. The same could be said of the lay crusades conducted during the period 1990-1998. As a result:

1. The new members were involved in church activities.

2. The new members shared their faith with their families and friends.

\footnotetext{
Ibid. , 18-20.
} 
3. The other church members were challenged to do the same.

4. Some pastors developed programs to equip the laity.

I learned the importance of the laity from my first pastoral crusade in 1984. In my first crusade, I did most of the evangelistic visits. Most of the church members did not nurture the new converts because the members were not acquainted with them.

During one of the pastoral crusades in 1985, I was responsible for field work. There were over twenty lay Bible workers studying with people, which resulted in more than one hundred new converts. The church members nurtured the new converts.

When I did evangelism in Tobago between 1986-1988, empowering and equipping the laity was a key factor for membership involvement and church growth. In 1988, the Bon Accord Seventh-day Adventist Church, Tobago, was the largest organized church in the conference, with ninety-one members, due to the work of ministry and laity.

When I worked in Trinidad from 1989-1998, as a pastor/evangelist, two churches were organized in every district because the pastoral staff shared ministry with the laity. Whenever pastors and laity shared ministry, the membership increased and there was a high rate of conservation. In some pastoral districts, pastors accounted for over 75 percent of new converts annually. Church 
81

members were not familiar with new converts from island-wide crusades because pastors/Bible workers did most of the evangelistic visits. There was a paradigm shift in evangelism when Evangelist Fitz Henry conducted an islandwide lay crusade in Trinidad. The ministry and laity shared evangelistic ministry, which resulted in over twelve hundred persons baptized. The conservation programs were done by the ministry and laity.

\section{Review of Church Ministry Programs}

The churches benefitted from the equipping models in the following ways:

1. Members were equipped and mobilized to be effective witnesses.

2. Members experienced a strong bond of nurture, worship, and mission.

3. Members connected with the community through community programs and projects.

4. A skills inventory of the members was developed.

5. A resource of leadership was developed among the laity.

6. There were a variety of lay ministries.

7. New churches were established.

The three equipping models needed the following criteria for greater program success: 
1. A strong embodiment of the vision and values of equipping ministry, along with adequate resources for success

2. A comprehensive system that included preparation and development of people through administrative systems, staff support and involvement, and celebration of success

3. A leader and team that had the authority and responsibility to share the vision and facilitate the ministry. ${ }^{1}$

The churches emphasized certain objectives more than others, for example, they developed programs that reflected their unique concerns. Like most programs, there were two imbalances, the teaching imbalance (equipping) and the activity imbalance (empowering). Although there were seminars to assist members in determining their spiritual gifts, members were often on their own to ascertain their gifts for ministry. The result was good programs, but few members were trained and served in ministry.

The activity imbalance was evident when ministry leaders kept good records on members, who were matched to a ministry, but were not empowered for the ministry. The members felt that the church's priority was to fill a vacancy in a program rather than to assist them to grow and contribute in their ministry. As a result, equipping ministries were sometimes seen as programs apart from the

\footnotetext{
${ }^{1}$ Mallory and Smith, 120.
} 
mission of the church, to provide volunteers for other programs. ${ }^{1}$

Pastors and laity underestimated the amount of time, energy, and expertise required to implement and facilitate a comprehensive equipping ministry. The length of the programs often lasted for one year and was affected when there was election of church officers. The laity feared changes because they believed they would lose something in the process. Since the conference did not place a high priority on empowering and equipping the laity for ministry, few pastors conducted equipping ministry programs.

${ }^{1}$ Ibid. , 122 . 
CHAPTER 4

STRATEGIES TO EMPOWER AND EQUIP THE LAITY

\section{Leading the Laity to Discover}

Their Spiritual Gifts

Among the characteristics of a healthy church is a strategy to engage persons in ministry. Such strategy has several characteristics, including encouraging volunteers and recruiting persons on the basis of certain criteria. The use of a variety of methods provides opportunities to find the best persons for needed ministries.

By "volunteering" is meant a method by which announcements of needs and services are made and then accepted by any of your members who step forth to take up the challenge. By "recruiting" is meant a method of directly and personally soliciting certain persons with known desired attributes to do a particular ministry. ${ }^{1}$

There are obvious dangers and weaknesses in both methods. In the volunteering mode there is always the danger of people who lack the necessary gifts and talents coming forward to take up the challenge. A way of reducing

${ }^{1}$ Charles Vernon Bryant, "Revitalizing Congregations Through Lay Visitation Ministries" (D.Min. dissertation, Drew University, Madison, NJ, 1987), 100. 
this danger is by incorporating in the announcements a statement about interviewing the respondents. Yet even this is not without problems. Some persons who suspect that a "screening" is being conducted, in order not to suffer the embarrassment of being rejected, will not respond at all. The assumed importance and quality of ministry needed will dictate the extent to which such risks should be taken.

Another way of reducing the danger of wrong persons volunteering is to make sure that enough information about the project is given. It is also essential to state explicitly what kind of persons and qualifications are required for the ministry being considered. The third way of reducing problems is to offer adequate training that will overcome any weaknesses.

Recruiting also has its problems. One of them is for the person/s responsible for recruitment to gravitate towards persons who are known never to say no. These "never-say-no" persons are already in too many things and are likely subjects for burnout. The other side of this is not taking the trouble to find underworked and overlooked persons to recruit. ${ }^{1}$

Another weakness in direct recruitment is that the recruiter may not be knowledgeable enough to know who should or should not be recruited. A part of this danger is that

${ }^{1}$ Marlene Wilson, How to Mobilize Church Volunteers (Minneapolis: Augsburg Publishing House, 1983), 86. 
one may feel emotionally drawn to certain persons and feel that they are "just right" for a particular ministry. This emotional attraction may blind a person to the fact that the recruit lacks the abilities, experience, and motivations that the project needs.

The strengths of either or both certainly outweigh the weaknesses. To use both methods knowledgeably is to provide a basis for success. But whatever method is used, either of the two or both together, there are principles that must be considered seriously.

1. The first principle of training members is that in the body of Christ there is never a "wrong" person in a place of responsibility; it is the right person in the "wrong" job. This is one of the major causes of burnout. Linking all persons to ministries consistent with their interests, temperament, and spiritual gifts is the great need of any local church.

Strategies for linking are ways of discovering people's interests, skills, temperaments, and gifts (charismata). Under this first principle I shall suggest a few strategies which are methods of implementing this principle.

a. One way is to distribute an inventory designed to surface the information needed. It is important to follow through with the information.

b. A second suggestion is for a leader to schedule presentations to all classes and other 
organizations to describe the ministries needed and the types of persons and qualifications needed.

c. A third strategy for linking persons with ministries is the personal interview. This is by far the slowest method, but it offers the greatest assurance of proper linking. The interview, according to Marlene Wilson, will have two special ingredients: (i) asking appropriate, open-ended questions that allow the other person to talk about him/herself, and (ii) interactive listening, that is, listening to hear and to understand what the other is saying, listening with patience, listening with a show of interest in what is being said, listening without interrupting, and listening for areas of agreements and strengths. ${ }^{1}$

d. A fourth method is to hold a Ministry Fair, modeled after the "Job Fair" often used in public schools. The leaders of the various ministries, located in rooms or booths in a fellowship hall, would be on hand with attractively designed materials and explanations of services they represent.

2. The second principle that will never go away is the need for information. People need to know as fully as possible what it is they are being asked to do, and why. They need to know when and for how long. They need to know what the requirements, Iimitations, and goals are; and what

\footnotetext{
${ }^{1}$ Ibid. , $56-57$.
} 
the situation is if the job is not done. If there is one single principle by which any ministry rises or falls, it is information.

3. The third principle is the necessity for training and equipping persons for ministry (Eph 4:12). I have discussed this in an earlier chapter in the context of the biblical perspective for ministry. What is emphasized here is that the need and cry for training is not only a biblical imperative, it is also the cry of informed human nature. It is the way of human nature: the more learned, the more there is to learn.

Lay people do not only ask "What am I to do?" and "Why am I to do it?" but also, "How am I to do it?"1. Training took up more time in our Lord's ministry than any other activity. He was constantly training His disciples. And the disciples trained the persons they were privileged to disciple. When it comes to the matter of laity caring and sharing contact ministries, training is a must. Here are some strategies that are necessary:

a. A job description is the beginning of training. This is a form of training that begins before the recruiting and volunteering begin. For every call to ministry there should be a carefully and simply worded description.

${ }^{1}$ Stanley J. Menking, Helping Laity to Help Others (Philadelphia: Westminster Press, 1984), 81-86. 
b. A schedule that accommodates the need to not be under pressure is essential. An outline of what will be covered and expected is important.

c. Actual practice as a learning tool is a must. One can read about ministry and become very knowledgeable about it; however, if the person is not given an opportunity to experience ministry, ministry is unreal to the person.

d. Observing a model is helpful. This is where role playing, viewing a film, or listening to a tape is productive. It is also helpful to make a video film of the actual role-playing of the group. The participants can see themselves and learn invaluable lessons to be acquired from no other place. When viewing other films, it is important to discuss beforehand some salient features of the subjects, what to look for, and then, after viewing the film, to debrief experiences of learning.

e. Discussion. If there is one thing that participants complain about the most, it is that they are not given enough time for discussion. What is really meant here? This is the biblical method and teaching about how God has gifted each member of the body of Christ, the Church, for a special ministry. This does not mean that calling for volunteers and personally recruiting for ministry cannot be in harmony 
with biblical teaching. It does mean that when members know their respective gifts for ministry (Rom 12:6; 1 Cor 12:7; Eph 4:7, 11-12; 1 Pet 4:10), as designed and empowered by the Holy Spirit, their motivation to respond to a need or call to fill a need will meet not only God's economy of ministering but also the real needs of all persons, including themselves. In my own experience a spiritual gifts workshop in local churches was very beneficial. ${ }^{1}$

In the book, Rediscovering the Charismata, Charles Bryant describes the effectiveness and excitement of persons who are motivated not so much by the challenge of a known need as much as by possessing a spiritual gift that is designed to fill a need. When persons discover their gifts for ministry (Eph 4:7-12; 1 Pet 4:10), they enthusiastically seek for opportunities to use them. In this context, the motivation to minister precedes the discovery of a need. ${ }^{2}$

It is not easy for ordained pastors and other wellqualified leaders to admit that their management skills may not fill the need to find the right persons for certain ministries. This is why it is imperative that we return to an informed understanding of what the Bible has to say about ministry and God's desire for the same. 'I believe this is

${ }^{1}$ Bryant, $104-107$.

${ }^{2}$ Charles V. Bryant, Rediscovering the Charismata (Waco, TX: Word Books, 1986), 73-75. 
what Paul is saying to us in Rom 12:1-2, which is not to pattern our organization and activities after secular models, but to change our direction toward seeking God's will (Rom 11:29). The question is, "How do I discover my gifts?" There are various ways to do this. An acronym that has become an effective method of discovering one's gift or gifts is OBEDIENCE. ${ }^{1}$

$0=$ OBEY God calling. Rom 11:29 says that the "gifts and calling of God are irrevocable." The word "gifts" here is charismata which, when found in the New Testament, always has a condition or command linked with it. "Calling" comes from the Greek word klesis that denotes a personal invitation. This suggests a ministry that is powerfully personal, one that comes from God. Obedience means to obey God. Let God be God!

$\mathrm{B}=$ BEGIN a study of the gifts. The old adage, "A call to ministry is a call to prepare" holds true here (1 Tim $4: 14 ; 2 \operatorname{Tim} 1: 6,7 ; 2: 15)$. To undertake an adequate study of the gifts includes three avenues of learning:

1. Read what the Bible has to say about the gifts. The Bible is the greatest teacher here (Rom 12; 1 Cor 12; Eph 4; 1 Pet 4).

2. Read a good book on the subject.

${ }^{1}$ The following paragraphs develop this idea, based on ibid., 138-152. 
3. Observe the lives of persons who obviously possess and obediently use certain gifts.

$E=$ EXAMINE feelings. Modern psychology is helping us to understand the value of feelings. When we deny and suppress feelings, we deny something very basic to health. As one experiments with various spiritual gifts, a fruitful test is to ask, "How do I feel as I do this? Does it feel right or wrong?" I cannot believe that God has given an irrevocable gift (Rom 11:29) without an inner mechanism that can help discover it. The imperative here is to examine feelings.

$D=$ DARE to commit yourself to the gifts. Thinking, feeling, and willing constitute the essence of living. Feelings are important; but the power behind healthy feelings is the power to will something. An effective component of the search for one's gifts is to activate the will toward what 1 Cor 12:7, Rom 12:6, Eph 4:7, and 1 pet 4:10 say about each person having a gift. This is to say, dare to make a commitment or try or experiment with one at a time until one feels right.

$I=$ INVESTIGATE the gifts of others. A remarkable way of learning about the gifts is to observe the gifts of others. God has given them for the "building up of the Body of Christ" (Eph $4: 12)$.

$E=$ EXPERIMENT with as many as possible. There are approximately thirty gifts found in the New Testament. If a 
person does not know what his or her gifts are, the necessity is to begin a systematic experimentation of them, one at a time.

$N$ = NEVER doubt God's word and promise. The Word says we have gifts. The Word explains why we have them. As we search for our gift, let us cling to the Word's promises.

$C=$ CENSURE all notions of pride or defeat. To obey God is to accept what is given. A gift is something given and not earned. The knowledge of the gift one possesses must never produce pride but humility; and not to have a certain gift must never produce a sense of defeat. God has in each gift a divine will in operation (Phil 2:13).

$E=\operatorname{EXPECT}$ God to produce the results. We do not always know what happens as the result of our obedience and we do not have to know in order to be obedient. The discovery and use of our gift is not to produce results that we desire, but to glorify God (1 Pet $4: 11$ ). Our participation through obedience frees God to bring about divinely designed results (Rom 12:2).

This section has examined three principles that are necessary for getting the most people engaged in ministry. The assumption is that not all people will respond to a call to volunteer, to personal recruitment, or to a challenge to discover their gifts. Wise leaders, therefore, will want to explore every avenue possible to help members to find their place of ministry. Another assumption is that an informed, 
well-planned, and artful implementation of all three principles discussed will assure any church of an ample supply of persons needed to revitalize a congregation through caring and sharing contact ministries.

If anything would be added to this discussion, it would be that someone or some group must be directly responsible for recruiting, leading volunteers, and assisting persons to discover their spiritual gifts for ministry. To be sure, the pastor is the key. However, there are cases where some pastors have no skills in appropriating persons for ministries that are right for them. In such a case, the pastor would be wise to delegate the responsibility to others, such as a trained group. Such personnel can place persons where the most effective ministry can be done. ${ }^{1}$

\section{Empowering and Equipping the Laity}

"Not by might, nor by power, but by my spirit saith the Lord of hosts," (Zech 4:6). Empowering the church in the twenty-first century will require the spirit of God to be infused in that work. So there is no claim made for the strategy presented here to accomplish anything apart from the presence of the Spirit of God. "Except the Lord build the house, they labor in vain that build it: except the Lord keep the city, the watchman waketh but in vain" (PS 127:1). The power is of God. Thomas Torrance says it well:

\footnotetext{
${ }^{1}$ Bryant, 111-112.
} 
"The church is nothing without God." 1 The empowerment will be God's blessing granted. No chance of achieving these goals is possible separate and apart from this blessing. The endowment of spiritual gifts described in Rom 12, and 1 Cor 12-14 was granted to the church in natural as well as miraculous forms in that first century. Today, those natural gifts, with the presence of the Holy spirit and Jesus Christ, and the providence of God, supply all our needs. It is God's Spirit that empowers us even though we cannot see the spirit, nor understand the spirit's comings and goings (John 3:3-9). Therefore, God works in and through our talents, our best efforts, and our faith. Consider the following ways that God empowers His church through the work of the Holy spirit.

\section{Empowered Through the Word}

Jesus said: "It is the spirit that quickeneth; the flesh profiteth nothing: the words that I speak unto you, they are spirit, and they are life" (John 6:63). Our faithfulness to this word is the only way to assure this empowerment .

\footnotetext{
"Thomas Torrance, "Foundation of the Church," in Theological Foundations for Ministry, ed. Ray S. Anderson (Grand Rapids: Wm. B. Eerdmans Publishing Company, 1979), 199.
} 
Empowered Through Obedience

Jesus was obedient to the Father, and as a result $\mathrm{He}$ had blessings which He said were predicated on that obedience. Jesus said: "Therefore doth my Father love me, because I lay down my life, that I might take it again" (John 10:17). He assures us that the principle applies to us: "Jesus answered and said unto him, If any man love me, he will keep my words: and my Father will love him, and we will come unto him, and make our abode with him" (John 14:23). Obedience is a natural part of the love for God and desire to serve Him. Jesus learned obedience through what He suffered (Heb 5:8-9), and encourages us to continue in that obedience if we are to be empowered with joy (John $15: 11)$.

\section{Empowered Through Prayer}

A leadership that prays has God's unlimited resources, and the Holy spirit's intercessions for carrying out its tasks (Rom 8:26). There is no greater resource that the church or its leadership has than this privilege of prayer.

Empowered Through Relationship With God

It is our relationship with God the Father, God the Son, and God the Holy Spirit that gives strength to our lives. It is this relationship with the divine that pervades our lives and makes Christians different. Jesus 
pervades our lives and makes Christians different. Jesus came into the world and was named Immanuel, "God with us." The goal of the leadership of the church is not to trust in its own power or wisdom or strength, but "to be strengthened with might by his spirit in the inner man; that Christ may dwell in your hearts by faith. . . that ye might be filled with all the fullness of God" (Eph 3:16)." These three are parts of the total resources promised to God's people. This makes possible what otherwise would be impossible. Notice how Paul words this: "Now unto him that is able to do exceeding abundantly above all that we ask or think, according to the power that worketh in us, Unto him be glory in the church by Christ Jesus throughout all ages, world without end" (Eph 3:20).

Empowered Through Mutual Participation

The body ministers to itself, not to be preoccupied with its own needs, but in order to minister to the world for God. We are enriched by God's blessings to His people in the spiritual gifts that are given to each one for the benefit of the entire body. "As every man has received the gift, even so minister the same one to another. . . that God in all things may be glorified" (1 pet 4:10-11; Rom $12: 3-21 ; 1$ Cor $12: 1-31)$.

${ }^{1}$ Albert L. Bergeror, "A Strategy for Empowering the Church Through Biblical Leadership Development" (D.Min. dissertation, Fuller Theological Seminary, Pasadena, CA, 1992), 206 . 
It requires the spiritual gifts received by the church to help us overcome all the human foibles and frailties that characterizes the church. It is important to note that the work that God has planned for the church to do cannot be accomplished by an individual alone. That's why the apostle Paul said, "the body is not one member, but many. . . But now hath God set the members every one of them in the body, as it hath pleased him" (1 Cor 12:14, 18). Therefore, it should be obvious that "it will take the whole church to take the whole gospel to the whole world." We need each other to accomplish God's work in us.'

\section{Empowered. Through Transformation}

Transformation involves the renewing of our minds: "And be not conformed to this world: but be ye transformed by the renewing of your mind" (Rom 12:2). This brings the power of the word and the power of God through the world into operation in our lives. ${ }^{2}$

Empowered by the Holy Spirit

The role of the church and the pastor in the process of training members is important, but if there is no transcending power accompanying this human effort, little will be accomplished. The vertical dimension in training lay leaders is very important. Only one Source can convict

\footnotetext{
${ }^{1}$ Ibid.

Ibid., 207.
} 
sinners of $\sin$ and give the spiritual power necessary to accomplish God's work, and that is the Holy Spirit. Without this power there is no worthwhile Christian service.

In Christian leadership, human ability, skills, and quality provide an insufficient substitute for spiritual power. The Greek word dunamis was used by Paul in reference to the dynamic power of the Holy spirit. He wrote to the Roman Christians: "May the God of hope fill you with all joy and peace as you trust in him, so that you may overflow with hope by the power of the Holy Spirit" (Rom 15:12, NIV). Paul also reminded Timothy that evidence of a spirit-filled life is demonstrated in power, love, and peace of mind. ${ }^{1}$

In 2 Cor 4:7, Paul referred to the power of the Holy Spirit in ministry. He said: "But we have this treasure in earthen vessels, that the excellence of the power may be of God and not of us." This dynamic verse, when studied in context, issues a clear call for competence through the Holy Spirit in Christian service.

When the disciples were in Jerusalem after the ascension of Jesus, they were not yet ready to start their ministry. They had received three years of training with Jesus, but they lacked power. They were in need of a greater enabling power in order to accomplish their mission. However, this was to be a complement to the original bestowal of gifts when they first accepted the call of

\footnotetext{
${ }^{1}$ See 2 Tim 1:7.
} 
Jesus. God could give other gifts in the future as the need arose for His work and for His glory. ${ }^{1}$ Meanwhile, the Holy Spirit had not yet come in a special way and they were unable to do the job. They needed the enabling and empowering of the Holy spirit.

Today, as for the disciples, this empowering is bestowed as the result of people seeking the presence of the Holy spirit. "But you will receive power when the Holy Spirit comes on you" (Acts 1:8, NIV). This power will make alive, bring together, put down the mighty from their seats, and exalt the lowly and meek. ${ }^{2}$ The role of the Holy spirit in providing power for the church is as valid today as it was for the early Christian movement. If the gospel is not accompanied by the transcendental power of the Holy spirit, everything is both fruitless and vain. "For the Kingdom of God is not a matter of talk but of power" (1 Cor 4:20, NIV). "The Holy spirit is the source of all transforming acts in the Christian History." $" 3$

Ellen White states that "the promise of the Holy Spirit is not limited to any age or to any race. Christ declared that the divine influence of His spirit was to be with His

'Sandra Bean, "Spiritual Gifts: A Layperson's Perspective," Celebration, August 1995, 6.

${ }^{2}$ Leonard I. Sweet, New Life in the spirit (Philadelphia: Westminster Press, 1982), 17.

${ }^{3}$ Ibid 


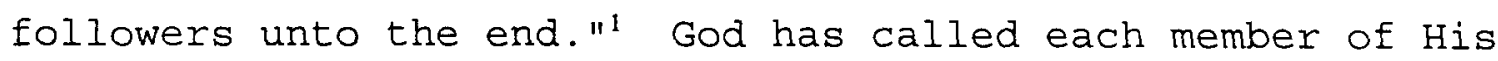
church to Christian service for Him, and through the Holy spirit spiritual gifts are bestowed. The goal of these spiritual gifts is to equip people for the ministerial work required for building up the body of Christ. When Christians use these spiritual gifts, Christ's objectives are accomplished. ${ }^{2}$

The Holy Spirit instructs, equips, and motivates God's people to join the ministry through the medium of spiritual gifts. In the early church, the Holy Spirit enabled the disciples to accomplish their divinely ordained task. The reception of the spirit was so important to the success of the gospel that Jesus told the apostles to wait until they received it. ${ }^{3}$

Each member in the body of Christ has a function, a purpose, a ministry, just as every part and organ of the body has a function and purpose. Though some claim they possess no gifts, Paul emphasizes in 1 Cor 12:7, 11, 18 that every member has a gift to be used in the church. It is a primary duty of the pastor of each congregation to aid

${ }^{1}$ White, Acts of the Apostles, 49.

${ }^{2} \mathrm{~A}$ study of the use of spiritual gifts in the church should help in the understanding of God's plan for the utilization of its people in ministry.

${ }^{3}$ George $\mathrm{E}$. Rice and Neal C. Wilson, The Power of the Spirit (Hagerstown, MD: Review and Herald Pub. Assn., 1991), 15. 
members in discovering their gifts. ${ }^{1}$ The function of the leader also lies in polishing, liberating, and enabling those gifts. ${ }^{2}$

The great purpose of the Holy Spirit in empowering people is to accomplish everything involved in the mission of the church. The Holy spirit is poured out for the accomplishment of the task of Jesus. The outpouring of the Holy spirit must never be considered separate from its great goal and function. ${ }^{3}$ "The spirit cannot be poured out unless there are people willing to be filled with power. "4

The Holy Spirit equips the members of the congregation with different spiritual gifts which perfectly match the personalities of individuals so they can feel comfortable and effective in their ministries. The spirit is a source of power for the church. The Spirit is a source of spiritual power for Christians and a source of successful ministry by the church as a collective enterprise.

\section{Equipping Process}

Equipping is an ongoing process that involves preparation, motivation, and formation of solid leadership.

\footnotetext{
${ }^{1}$ Roy Naden, "The Holy Spirit and Evangelism," Ministry, March 1993, 9.

${ }^{2}$ Max DePree, Leadership Is an Art (New York: Bantam Doubleday Dell, 1989), 10.

${ }^{3}$ Burrill, Revolution in the Church, 16.

${ }^{4}$ Ibid.
} 
The pastor cannot neglect this important aspect of mobilizing laity to be ministers and to become strong spiritual leaders in the church.

When the pastor follows the steps that have been presented so far, he/she will create a healthy awareness about spiritual gifts and a climate of participation and involvement in the church ministry. Church members want to be engaged in the ministry of the church. At this point it may be that the pastor will have more volunteers for church functions than there are offices available. At this moment, the pastor and leaders cannot disappoint those who are willing to work. Members need to have the opportunity to use their gifts and talents, and the church has the responsibility to provide those opportunities. 1

\section{Training}

Training is a fundamental part of the equipping process. A fundamental function of pastoral ministry is training church members to excel in the area of their giftedness. A basic and regular training program with the purpose of supporting and equipping them is vital. Time spent in leadership training enables church members to grow and eventually lighten the pastor's workload. The laity must be trained to be ministers, and opportunities for

\footnotetext{
${ }^{1}$ Paulo Cesar Nogueira, "Equipping Laity for Ministry in Multi-Church Districts in Brazil" (D.Min. dissertation, Andrews University, Berrien Springs, MI, 1999), 130-131.
} 
ministry must be created by them and for them. ${ }^{1}$ Burrill points out that "training is the best nurture that can be given to God's people."2 Kirk Hadaway defines training in the church as "an interactive process whereby members gain knowledge and skills, and then create their own unique ways of applying what they learned in ministry." ${ }^{3}$

In the equipping process, training is not only something mechanical and technical; it includes motivating, setting goals, nurturing, instructing, exhorting, building up convictions, inspiration, knowledge, skills, and so on. It also includes much practice and continued improvement in light of the feedback received. There is no quick and easy way to become equipped; equipping involves a lifetime, an unalterable purpose to use one's gifts, talents, and abilities for ministry. Training in this context is more than a weekend seminar once a year. It is an interactive and an ongoing process that involves strong relationships. ${ }^{4}$

\section{The Need for Training}

Church members need training for several reasons.

${ }^{1}$ Normal Shawchuck and Gustave Rath, Benchmarks of Quality in the Church: 21 ways to Continuously Improve the Content of Your Ministry (Nashville: Abingdon, 1994), 60.

2Burrill, Revolution in the Church, 52.

${ }^{3} \mathrm{C}$. Kirk Hadaway, Church Growth Principles: Separating Fact from Fiction (Nashville: Broadman, 1991), 106.

${ }^{4}$ Norton, Class notes for CHMN664. 
1. To help church officers and committee members understand the purpose of their being elected and why they exist as an organization. If church members do not have a complete understanding of their purpose, they probably will never be effective in their functions or ministry: Here, a brief description of the job and its purpose is essential.

2. To understand what to do and how to do it, regardless of ministry opportunities. Once people are matched for these tasks, they need to be trained to be effective. Retraining the members is often necessary, especially in the implementation of a new ministry.

Training creates renewed enthusiasm and gives new motivation to work as volunteers. ${ }^{1}$

3. To develop leadership, interpersonal relationships, communication, and technical skills. With the development of these skills, lay leaders will become more and more efficient in performing their duties. Additionally, the quality of their work will improve, and the church will experience qualitative and quantitative growth.

4. To develop a sense of responsibility and commitment.

5. To provide resources and motivation to get people involved in ministry. People more readily volunteer for

${ }^{1}$ Dennis E. Williams and Kenneth O. Gangel, Volunteers for Today's Church: How to Recruit and Retain Workers (Grand Rapids: Baker, 1993), 103. 
church work when they know they will be given the resources to succeed. ${ }^{1}$

\section{Training in Multi-Church Districts}

The pastor in multi-church districts should give two types of training: general skills training and specific training for a given ministry. General training is important for all workers, and should include skills in different areas of ministry, such as spiritual discipline, and personal growth. Specific training is targeted to the particular assignment a person is expected to fill. ${ }^{2}$ Some ministries require professional attention on a continuing basis. In such areas the pastor should ask for professional help to do this training.

When the pastor has many churches and companies in several cities, he could divide his district into two or three geographical areas, with a training center in each area for seminar training. The pastor who has several churches and companies in one city could make a system of rotation where the general session occurs in one of the churches or in a different area of the city each quarter. The officers of each congregation are invited to attend general training sessions. ${ }^{3}$

${ }^{1}$ Shawchuck and Rath, 60.

${ }^{2}$ Douglas W. Johnson, Empowering Lay Volunteers (Nashville: Abingdon Press, 1991), 80-85.

${ }^{3}$ Nogueira, 137 . 
General training seminars could be a special time for inspiration, orientation, and motivation for the ministries of the church. The seminars should have a time slot for personal testimonies by church members so the people in different churches and companies of the district can hear how others are doing their ministry.

In addition to the general training session, a network of training must provide specific training focused on specific needs of each church and region. This is true especially when new ministries are implemented. Due to the complexities and peculiarities of every ministry, the needs and skills of each ministry are singular. The leader of music will need skills different from the leader of the deacons. The pastor needs to be prepared to support every church volunteer in all areas of ministry.

A local training session should take from ninety minutes to two hours, including group discussion, lab learning experiences, and time for review and questions. The pastor's role must be that of a facilitator, not a lecturer. The schedule of meetings should take into consideration time convenience for both the pastor and church member. ${ }^{1}$

Carl George and Robert Logan suggest four steps in the process of teaching: first, "I do, you watch" (modeling and observation); second, "I do, you help" (modeling and

${ }^{1}$ Ibid. ، 138. 
participation); third, "You do, I help" (assisting and evaluation); fourth, "You do, I watch" (encouragement). ${ }^{1}$

In this equipping process, the pastor could plan an annual retreat when church officers will receive acknowledgment and recognition for their work, a time when they are encouraged to continue to do their best for the Lord. Plans could be made for the upcoming year. Mainly, it should be an occasion for church leaders to spend quality time in Christian fellowship.

The pastor needs to consider two important points. First, although pastors are the key factor to provide training for church officers, they do not need to do everything alone. The pastor needs to delegate tasks. He/she should find knowledgeable persons to train the laity. Usually there are people with experience and skills to share in a specific training program. If no such persons are in a district, laity from other districts and even conference pastors should be invited to do the training. What really matters is not who is doing the training, but getting it done. Second, training involves practice; theoretical knowledge and skills must be followed by practice. Church

${ }^{1}$ Carl F. George and Robert E. Logan, Leading and Managing Your Church (Old. Tappan, NJ: Fleming H. Revell, 1987), 110 . 
members must have the opportunity to put into action what they have learned in training sessions.

\section{Motivation}

It is almost universally agreed that motivation happens inside an individual and the motivation of that individual influences personality, needs, expectations, and perceptions. Whatever is inside a person that makes activity continue has been referred to as motivation. ${ }^{1}$

The word "motivation" comes from the original French and Latin, and means "moving." The word itself means something that causes a person to act. ${ }^{2}$ John B. Miner defines motivation as "those processes within an individual that stimulate behavior and channel it in ways that should benefit the organization as a whole." ${ }^{3}$ R. Dennis Middlemist and Michael A. Hitt, on the other hand, define motivation as "the forces acting on and coming from within a person that

\footnotetext{
${ }^{1}$ Douglas Robert Kilcher, "Pastoral Morale and Motivation: The Relationship of Selected Attitudes and Variables to Job Satisfaction With a View to Increasing Ministerial Effectiveness" (D.Min. dissertation, Fuller Theological Seminary, Pasadena, CA, 1987), 137.

${ }^{2}$ Bernard M. Lall and Geeta R. Lall, New Dynamic Leadership (Berrien Springs, MI: Geetanjali Publishers, 1994), 273 .

${ }^{3}$ John B. Miner, Organizational Behavior: Performance and Productivity (New York: Random House, 1988), 158.
} 
account, in part, for the willful direction of one's efforts toward achievement of specific goals." 1

For Gary Johns, motivation means three things: "The person works hard; the person keeps at his or her work; and the person directs his or her behavior towards appropriate goals." These definitions all seem to contain three common aspects of motivation: effort, persistence, and direction. ${ }^{2}$

Motivation, then, is an exchange between a person and the environment which directs his/her behavior, arouses interests, and sustains actions with and without an organization. The organization provides the framework within which a person expresses his/her motives and drives.

Christian Motivation

Is there a difference in the way Christians are motivated to do their work? Does lower salary, shorter holiday periods, and lack of other fringe benefits prevent a Christian from being of maximum service to an organization? A number of research studies have shown that pay is not the primary motivator of workers. ${ }^{3}$

A Christian is motivated by broader goals and objectives. Many church workers could earn double or triple

${ }^{1} \mathrm{R}$. Dennis Middlemist and Michael A. Hitt, Organizational Behavior: Managerial Strategies for Performance (St. Paul, MN: West, 1988), 144.

${ }^{2}$ Gary Johns, Organizational Behavior: Understanding Life at Work (Glenview, IL: Scott, Foresman, 1983), 173.

${ }^{3}$ Lall and Lall, 289. 
payment working for the government or other agencies.

However, these workers remain within the church primarily because they are convinced that the church has broad goals and the objective is to spread the gospel to every corner of the earth, to warn every soul and hasten the Lord's coming.

"True refinement will never be revealed so long as self is considered as the supreme object. Love must dwell in the heart. A thorough-going Christian draws his motives of action from his deep heart-love for his Master."1

This should be the source of all motivation for Christians--love for fellow beings stemming from heartfelt love for the Master. "The son of man is come to seek and to save that which was lost" (Luke 19:10).

As for the foundation of every act and motive, Ellen White points out: "Whether therefore ye eat, or drink, or whatsoever ye do, do all to the glory of God." Here is a principle which lies at the foundation of every act, thought, and motive; the consecration of the entire being, both physical and mental, to the control of the spirit of God. ${ }^{2}$

Whatever task a Christian worker performs should bring glory and honor to the Maker. To accomplish this is not an easy task. Writing about ministers, Ellen White says:

\footnotetext{
'White, Gospel Workers, 123.

${ }^{2}$ White, Testimonies, $3: 84$.
} 
By a close scrutiny of their daily lives under all circumstances, they would know their own motives, the principles which activate them. This daily review of our acts, to see whether conscience approves or condemns, is necessary for all who wish to arrive at the perfection of Christian character. ${ }^{1}$

This same principle applies to all workers. Christian workers should remember that God inspects their motives. Ellen White in this regard states: "Many receive applause for virtues which they do not possess. The searcher of hearts inspects motives, and often the deeds which are highly applauded by men are regarded by Him as springing from selfish motives and base hypocrisy."2

Interestingly, God counts not the results, but the motives in achieving such results. Ellen White says, "It is not the great results we attain, but the motives from which we act, that weigh with God. He prizes goodness and faithfulness more than the greatness of the work accomplished." 3 Yet God provides a guideline for individual motive power. Ellen white points out that "the great motive powers of the soul are faith, hope, and love; and it is to these that Bible study, rightly pursued, appeals." 4

\footnotetext{
${ }^{1}$ Ibid., $2: 512$.

${ }^{2}$ Ibid.

${ }^{3}$ Ibid., 2:510, 511.

${ }^{4}$ White, Education, 192.
} 
Motivation Strategy

Everybody needs to be motivated. Charles Schwab says, "I have never seen a man who could do real work except under the stimulus of encouragement and enthusiasm, and the approval of the people for whom he is working." question in pastoral circles today is, How are people motivated for volunteer ministry? Malphurs observes, "You can only motivate people when your motivation comes from God. " 2

Douglas Johnson gives some strategic steps that the local church can follow regarding commitment, rewards, and motivational events. All could be a source of motivation.

1. An actual commitment service. At the beginning of the year a commitment service can be planned for volunteers who are beginning their jobs and those who want to renew their commitment. The pastor can call them to the front of the congregation and pray for them. A card could be prepared for this occasion called "My Commitment to the Service of the Lord."

2. Celebration of service. The end of the year is a good time to plan a special day to affirm and celebrate lay ministry. This special day must be one with a festive

${ }^{1}$ Charles Schwab, quoted in Bob Bilhi, Thirty Days to confident Leadership (Nashville: Broadman and Holman, 1998), 155.

${ }^{2}$ Aubrey Malphurs, Developing Vision for Ministry in the 21st Century (Nashville: Abingdon, 1990), 26. 
atmosphere and one that gives recognition for the work that the volunteers have done. Sabbath would be the best day for this event. The church should include a special section called "Our People in Ministry." A list of the volunteers and their respective ministries should be included in the bulletin. The church should give each volunteer a concrete token of appreciation. This token can be a certificate, a pin, a new book, or a Bible. ${ }^{1}$

3. Fishing-pool events or a festival of faith. Once every three months, church members could gather for a festival of faith. Church members involved in ministry should praise the Lord and share experiences and testimonies. Fishing-pool events have two main purposes: (a) to provide an outstanding opportunity to renew the purpose of using gifts to God's service, and (b) to recruit inactive people to ministry.

Douglas Johnson sees these occasions as great opportunities to increase each church member's understanding of Christ's call to service and to acquaint the congregation with areas of possible ministry. He also suggests distributing a.list of "ministry opportunities," indicating the number of people involved and the members needed in various ministry tasks. It is important to make contact

\footnotetext{
Johnson, 109-110.
} 
with those who complete the interest surveys to discuss possible areas of involvement and a course of training. ${ }^{1}$

$$
\text { Motivating the Laity to witness }
$$

It is important that pastors motivate the laity to serve others. Without the assistance of volunteer service, the pastor cannot fulfill all the ministries needed by the church. Indeed, no one person can possess all abilities needed in ministry. Unfortunately, many pastors are not skilled in motivating the laity to witness. Many pastors are rather passive about motivating the laity for ministry. There are three reasons for this type of passive attitude towards motivating and mobilizing on the part of the laity.

1. Many church members are too busy, working to support their families. Since they are so occupied, it is hard for them to spend time in weekday ministries.

2. The laity oftentimes sees ministry as the duty of the pastors. As such, church members are very reserved in sharing the gospel with others.

3. Unfortunately, most pastors have not been trained to motivate the laity for ministry.

\section{Principles of Motivation}

Pastors should know the principles of effective motivation for ministry. Herbert Bryne has given a summary

${ }^{1}$ Nogueira, 154. 
of principles which increases the likelihood of motivation and participation by volunteers. These principles can be applicable to the South Caribbean Conference of Seventh-day Adventists.

1. Goal setting. The first principle of motivation is setting goals, which must be compatible with the goals of the church.

2. Flexibility. Motivation must be so flexible that both type and degree of motivation may be varied to produce the desired results.

3. Leadership. Leaders must put themselves in the place of followers, to empathize with them, and to help them to understand what the leaders, the church, and God wants of them. Such understanding can become a driving force for work.

4. Mature Leaders. Strong direction may be needed at first, but as time moves on and both leaders and followers gain more experience working together, such leadership matures to the point where more freedom is given to followers.

5. Internal Motivation. All external motivation ultimately must produce internal motivation if it is to become effective and permanent. Leaders must believe in their followers and let them know it.

6. Inter-personal Relationships. People are motivated by those for whom they have a feeling of respect. Thus, 
effective motivation is accomplished by establishing open, honest, and sincere communication in an atmosphere based on mutual respect which results from fairness.

7. Participation. Participation is the key to motivation. Leaders should act as moderators, calling workers together, pooling their knowledge and experience, and cooperating in setting goals and making plans.

8. Give Credit. For many people, recognition is far more important than rewards, even including money. Therefore, greater motivation is obtained when leaders give credit where credit is due and also are willing to share blame where necessary.

9. Authority, Responsibility, and Accountability. People must be given the personal authority and responsibility to perform their assignments. In turn, they must be held accountable for a satisfactory performance. This principle is often misused or neglected in church work. Leaders should get volunteers started in the right direction and then monitor their progress, letting them know when corrections are needed.

10. Self-Motivation. The greatest motivation is selfmotivation. If leaders can get volunteers to set personal priorities which are in harmony with church priorities, self-motivation will encourage people to want to do their best to accomplish the purpose of the church. Leaders must demonstrate a spirit which genuinely respects the worth of 
the individual, considers his/her rights, and trusts his/her capacity for self-direction in order to become the most effective motivators.

There are many important examples of self-motivation in the witness of Peter and John in the New Testament.

But to stop the thing from spreading any further among the people, we must warn these men to speak no longer to anyone in the name of Jesus. But Peter and John replied: Judge for yourselves whether it is right in God's sight to obey you rather than God. For we cannot help speaking about what we have seen and heard. After further threats they let them go. (Acts $4: 17-21$ )

Peter and John spoke boldly about Jesus Christ without fear in spite of threats and persecution. They were motivated by love and the Holy Spirit. The apostle Paul also said, "Woe to me if I do not preach the gospel" (1 Cor $9: 16)$.

It is evident that Christ is the greatest motivator for His people. Paul stated, "I am sure that neither death, nor life, nor angels, not principalities, nor things present, nor things to come, nor powers, nor height, nor depth, nor anything else in all creation, will be able to separate us from the love of God in Christ Jesus our Lord" (Rom 8:3830).

Ellen White also emphasizes that Jesus Christ, who dwells in the hearts of Christians, is the greatest Motivator for ministry:

No sooner does one come to Christ than there is born in his heart a desire to make known to others what a precious friend he has found in Jesus, the saving and sanctifying truth cannot be shut up in his heart. If 
we are clothed with the righteousness of Christ and filled with the joy of His indwelling Spirit we shall not be able to hold our peace. ${ }^{1}$

Ellen white indicates the important relationship

between the love of Christ and Christian motivation. In addition to the love of Christ, another great motive for service will be experienced when God's people truly understand the value of one soul. Ellen White said, "The soul is of infinite value. Its worth can be estimated only by the price paid to ransom it. Calvary! Calvary! Calvary! will explain the true value of the soul." ${ }^{2}$

She further states: "We need to esteem souls above money. If you know of a higher work in the world than the work of soul saving, a work which will bring better results for investment of means, will you not tell us of it, that we may measure its value?"3

Truly, the soul is of infinite value. Only Calvary can explain the true value of a soul. When a Christian really understands it, he/she can serve and witness to others. Indeed, "God desires only the service of love." ${ }^{4}$ Thus, love

\footnotetext{
${ }^{1}$ White, Steps to Christ, 53.

${ }^{2}$ White, Testimonies for the Church, 3:188.

${ }^{3}$ Ibid. , $9: 57$.

${ }^{4}$ White, The Desire of Ages, 22.
} 
is the greatest motivator to inspire the laity for ministry. ${ }^{1}$

Therefore leaders cannot create self-motivation in other people. Motivation must come from within. However, we can create the climate and the atmosphere that lead to motivation. God has already motivated us by setting the right climate so the motivation can take place. God has provided the most powerful reasons for us to act. These reasons are:

1. God's Love.

2. Salvation in Christ.

3. Forgiveness of Sin.

4. Sonship.

5. The Conviction That Christ Is With Us.

The basic responsibility of every minister is to educate and train the members in his/her congregation by making them aware through education of their witnessing potential and responsibility.

In helping church members to identify and establish goals for themselves, they become more motivated. Furthermore, all such goals have to be compatible with the goals of the local church.

${ }^{1}$ Akeri Suzuki, "Preparing Pastors to Train Laity for Church Growth in the Seventh-day Adventist Church in Japan" (D.Min. dissertation, Andrews University, Berrien Springs, MI, 1998), 114-121. 
The best way to motivate is to encourage commitment through participation, decision making, and the acceptance of responsibility. Christian service is an opportunity for a person to achieve fulfillment of his/her highest needs. A church can do many good things, but there are some things a church must do if it is to achieve its mission. Training the church members is one of these priorities.

The only way a church can have an effective education, outreach, and mission program is through an efficient training program. The main function of the church is to help its believers become aware of the particular ways in which they can witness; and the principal activity of the minister is to train and guide the church members. ${ }^{1}$

Some activities and attitudes that could be helpful to motivate people for volunteer work are the following: ${ }^{2}$

1. Preaching and personal care: Church members well fed by the preaching sermon and personal care are more susceptible to be motivated.

2. Sense of belonging: People are motivated and commit themselves to a church where they feel wanted. This motivating component is rooted in the innate human need for social relationship. For some people, a sense of belonging

${ }^{1}$ Miled Modad, "Developing and Implementing a Training Program in Public Evangelism for Lay Members of the Hispanic Seventh-day Adventist Churches of the Wisconsin Conference" (D.Min. dissertation, Andrews University, Berrien Springs, MI, 1989), 74-80.

$$
{ }^{2} \text { Nogueira, 152-153. }
$$


is all they need to be motivated. They feel highly motivated in a climate where they sense they are a vital part of the team's mission.

3. Compassion and love: The ultimate motivational force in the universe is love. The love of Jesus in the heart and the sense of God's call are the greatest strengths that move men and women to service.

4. Recognition: Everyone likes to be recognized. Unfortunately, the task of saying "thank you" to volunteers is neglected by many pastors and churches. Somehow the church needs to plan how to express formally and informally its recognition of those who are working for the Lord. ${ }^{1}$ Giving personal and public appreciation of effort and positive performance is recognition. ${ }^{2}$

5. Rewarding: This element is rooted in the innate human desire for power and material things. Rewards can be "intangible," such as increasing authority, promotion, time off; honorific or "tangible," such as prizes, ribbons, plaques, certificates, and material things. ${ }^{3}$ All rewards must appeal to unselfish and pure motives for service.

\footnotetext{
'Johnson, 109.

${ }^{2}$ Norton, Class notes for CHMN638.

${ }^{3}$ Ibid.
} 
Developing Church structures to

Facilitate a Shared Ministry

Ministry: A Shared Responsibility

Membership growth and involvement are the result of corporate witnessing by the church. But when it comes to pastoral care, it has been commonly understood as primarily the duty of professional pastors. The biblical model of ministry is essential so the church becomes an entity where the "church does ministry and the leaders or pastors coordinate the gifts of the members and channel them for service within the body and to the wider community. Only then can ministry become a shared responsibility between leaders and members. ${ }^{1}$

\section{Strategy for a Shared Ministry}

Three steps help the church become a ministering community. Pastors must believe that ministry is for the whole church. The pastor's role must be broadened, and a new structure or model is needed for providing every possible opportunity for the members of the church to serve.

\section{Ministry for the whole Church}

For the church to become a ministering community, the members must recognize their value and gifts. They must

${ }^{1}$ Aaron M. Lopa, "The Role of the Pastor in Lay Development in the Seventh-day Adventist Church in Papua, New Guinea" (D.Min. dissertation, Andrews University, Berrien Springs, MI, 1996), 113 . 
realize they are needed in the total ministry of the church. It means they learn the following fundamental biblical principles.

1. Every member is important. In the body metaphor, some members are more prominent and visible but they are never more important, as each has a role to play. The value of a person is not based on his or her gifts. Gifts are given for ministry, not to determine value.

Warren writes: "There are no little people in the body of Christ and there are no insignificant ministries." 1

2. Every member is a minister. While not every member is a pastor, every member is a minister because each member is saved for ministry, called for ministry, gifted for ministry, and commanded to minister. The members of the church are saved to serve.

3. Members need to realize they are needed. Every member must see that the church as the body needs his or her talents and gifts. As members of the body of christ, each member is dependent on the other. The church cannot become a ministering community unless the members see and recognize their value and how important they are to God, the church, and its ministries. ${ }^{2}$

\footnotetext{
${ }^{1}$ Rick warren, The Purpose-Driven Church: Growth without Compromising Your Message and Mission (Grand Rapids, MI: Zondervan, 1995), 368 .

${ }^{2}$ Lopa, 114-115.
} 
Pastors as Trainers of

Lay Leaders

For the church to become a ministering community, the pastors must not only be doers of ministry but focus on being equippers. Their function now is to become developers of leaders who will, in turn, train their own members. The goal is to eventually have the whole church equipped for ministry. This is the way ministry was in the New Testament church (Eph 4:11, 12). The role of the pastor becomes crucial to equipping the church to become a ministering community. We need to return to this biblical model of pastoral care.

Unfortunately, when the Reformers broke away from Rome in their theology on salvation, they never made the break from the church of Rome in their theology on ecclesiology-leadership was from top down. The clergy were the main performers of ministry, thus priests within the priesthood.1

\section{Structure for a Shared Ministry}

The New Testament emphasis is on body ministry not on multi-gifted pastors. A structure is needed that will provide opportunity for the multi-gifted members to use and exercise their gifts, transforming them from being spectators to actors in ministry. What kind of structure would be suitable for providing the opportunity for many members to exercise their gifts?

\footnotetext{
logden, 52 .
} 
The small-group structure, more than any other structure, has the potential to develop lay leaders and mobilize their body ministry. It calls members out of the audience to become actors and performers of ministry. The success of Paul Y. Cho also is based on the cell-group concept.' The house churches were responsible for the secret of the growth of the early church. Ellen white writes:

The formation of small companies as the basis of Christian effort is a plan that has been presented to me by one who cannot err. If there is a large number in the church let members be formed into small companies, to work not only for the church members but for unbelievers also. ${ }^{2}$

In other words, White advises that our churches should form small groups for service. The small groups provide structure for (1) effective nurturing and caring, (2) developing lay pastors and their gifts, and (3) reaching out to unbelievers in the community--where all. members can serve and exercise their gifts.

The pastor's primary concern is to develop capable lay leaders of the small groups to share the function of nurturing. The development of lay leaders is a crucial step in the success of the small-group units. Carl F. George says :

${ }^{1}$ Paul Y. Cho, Successful Home-cell Groups (South Plainfield, NJ: Bridge Publication, 1981), 64.

${ }^{2}$ Ellen G. White, Evangelism (Washington, DC: Review and Herald, 1946), 115. 
Small groups are not the solution to what the church needs most desperately. Rather, churches rise and fall on the availability of trained, talented, and spiritually gifted leadership. And the best possible context anyone has ever discovered for developing leadership occurs because of a small group. ${ }^{1}$

The small group is the best structure for allowing opportunities for a shared ministry. But its success depends entirely on the availability of leaders to make it function. The pastor's role as an equipper is crucial.

The Jethro model (see fig. l) is an excellent biblical model to facilitate a shared ministry. In Exod 18:17-26 Jethro instructed Moses, his son-in-law, to delegate responsibility to capable people who could serve as leaders of thousands, hundreds, fifties, and tens. These leaders would be responsible to Moses and for those under their care. Let us consider the Jethro model.

The "M" represents leaders of thousands, the "C" the leaders of hundreds, the "L" the leaders of fifties, and the "X" the leaders of tens. The M supervises ten Cs, a C leader supervises two Ls, and an L leader supervises five Xs. This model has six basic values:

1. One man is insufficient for doing the job (vs. 18).

2. People need to be trained and equipped (vs. 20).

3. People need to be selected carefully (vs. 21).

4. Caring must get down to "bite-size" (vs. 21).

${ }^{1}$ Carl F. George, The Coming Church Revolution: Empowering Leaders for the Future (Grand Rapids: Fleming H. Revell, 1994), 48 . 


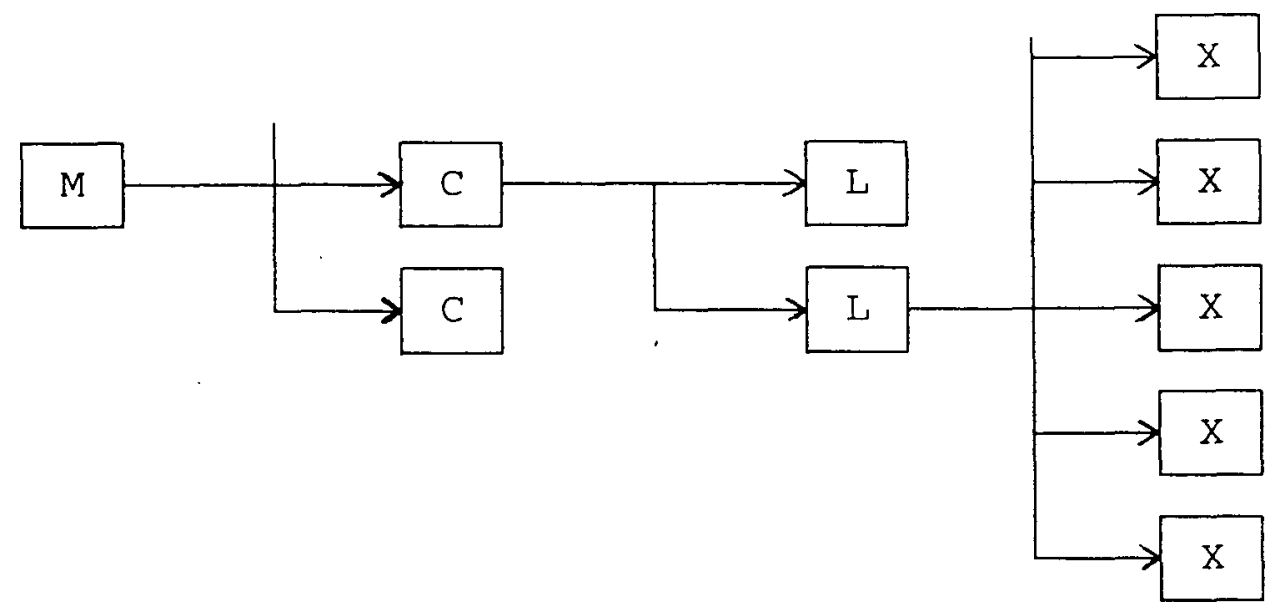

Fig. 1. The Jethro Model. Source: Carl F. George, The Coming Church Revolution (Grand Rapids: Fleming $\mathrm{H}$. Revell, 1990), 55.

5. The concept of delegation is valued (vs. 22).

6. Results are positive (vss. 22, 23).1

While this old Testament structure is good, it lacks

New Testament dynamics. In the New Testament, ministry was not delegated as suggested by the Jethro model. In the New Testament, all members had their own specific ministries according to their gifts. Ministry, then, is not delegated; those who minister must discover their gifts and unleash them for service. ${ }^{2}$

${ }^{1}$ Melvin J. Steinbron, Can the Pastor Do It Alone? A Model for Preparing Lay People for Lay Pastoring (Ventura, CA: Regal, 1987), 42 .

${ }^{2}$ Lopa, 119. 
Moreover, the Jethro model must be adapted to the scenario where churches have fewer than one thousand members, but most pastors in the South Caribbean Conference care for more than one church, sometimes as many as five churches. In the South Caribbean Conference setting, I will represent pastors by the letter $D$, as leaders of five hundred or more members. The Cs represent leaders of hundreds, the Ls leaders of fifties, and the Xs leaders of small group units. (The letters $D, C, L$, and $\mathrm{X}$ are used from the Roman numerical values.)

The Cs represent elders who manage, organize, and oversee the worship services and the administrative aspects of the church. The Ls represent some elders and some lay members who have the gift of leadership. They are equipped by the pastor for their function as coordinating and training leaders.

The main responsibility of the $\mathrm{Ls}$ is to develop the $\mathrm{X}$ leaders and $\mathrm{Xa}$ apprentice leaders so a continual supply of trained leaders is available. (The lower case "a" in "Xa" is used to indicate an apprentice.) The small-group units cannot function effectively if the church does not constantly develop and multiply the number of $\mathrm{x}$ leaders.

The success of the small-group system rises or falls on the availability of the $\mathrm{X}$ and $\mathrm{Xa}$ leaders. As can be seen in fig. 2, the Ls have a crucial role because they are directly responsible for the training of the $\mathrm{X}$ and the $\mathrm{Xa}$ leaders. 
The Ls are equipped by the D. Hence, how well the Xs and Xas are developed depends on how well the $\mathrm{D}$ equipped the $\mathrm{L}$ leaders, who, in turn, trained the $\mathrm{x}$ leaders. In this model, the Cs care for the administrative aspect of the system and are not directly involved in the equipping programs.

Again, the development of the Xs and Xas is crucial to the success of the small-group units. Thus, pastors (D) must spend more time in the training and equipping ministry to develop small-group leaders so enough $\mathrm{L}$ and $\mathrm{X}$ leaders will be available to provide effective caring.

There are advantages to this structure or model.1

1. It is not limited by facilities. Meetings can be held just about anywhere.

2. It promotes interpersonal relationships. The small-group units complement corporate worship where people become persons and names.

3. It enhances the assimilation process, especially of the new members. Recent members feel more at home within the small-group units. It also "assures the highest level of care at the lowest level of the structure." 2

4. It is not Iimited by finances because small groups can meet anywhere with minimal cost.

${ }^{1}$ See Aubrey Malphurs, Planting Growing Churches for the 21st Century (Grand Rapids: Baker, 1992), 215-20.

${ }^{2}$ George, The coming Church Revolution, 57. 


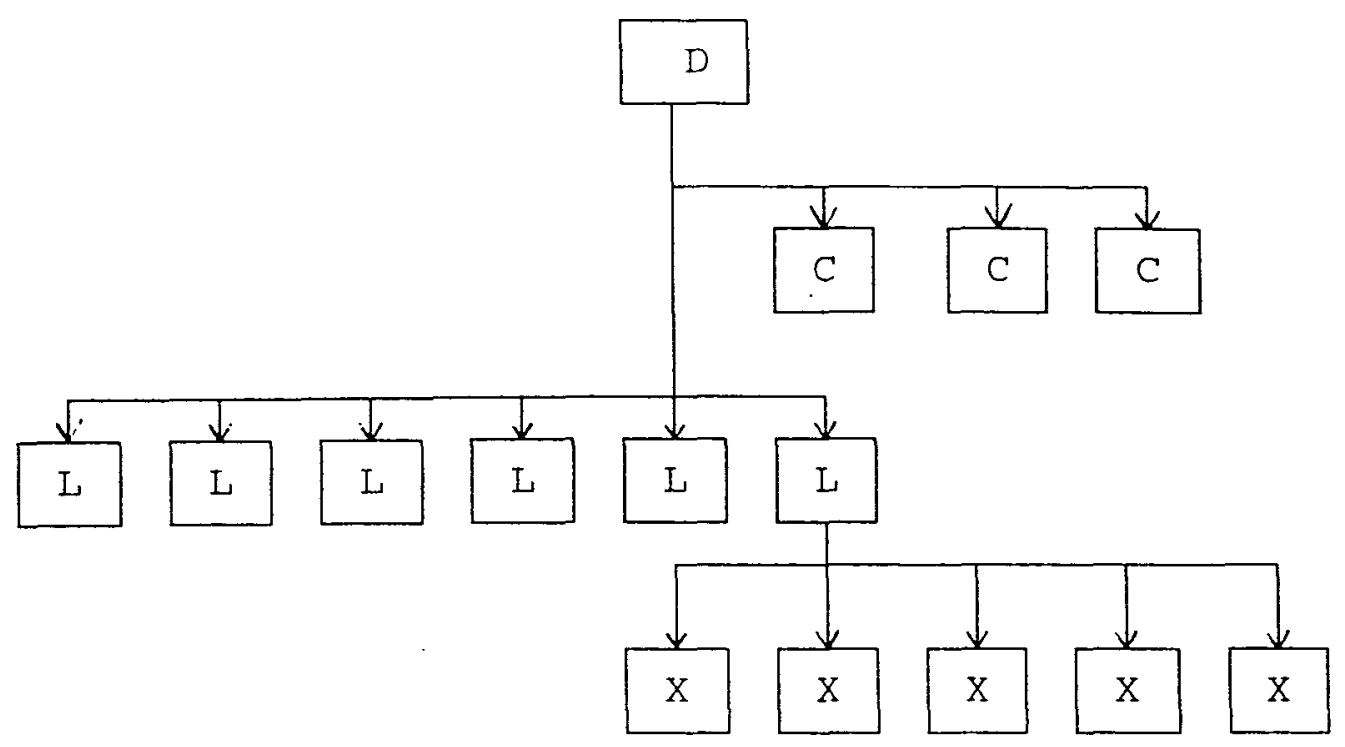

Fig. 2. Structure for developing small group unit leaders. Source: Carl F. George, The Coming Church Revolution (Grand Rapids: Baker, 1990), 58.

5. It is geographically expandable. Members can meet in a house, so meetings are not limited by location.

6. It encourages lay ministry and facilitates leadership training. The small-group unit becomes a stage where members exercise their gifts in order to develop them.

7. It decentralizes pastoral care.

\section{Smal1-Group Lay Ministry Program}

The development of lay ministry through small groups in the church does not happen by chance. It requires two vital steps: planning and training. Like two wings on an

${ }^{1}$ Lopa, $119-122$. 
airplane, planning and training are essential components of an effective small-group ministry. ${ }^{1}$

Well-planned, small-group programs that are not accompanied by proper training for potential small-group leaders are likely to fail because many lay leaders do not know how to lead effective small groups. Conversely, programs with well-trained group leaders may very well fail because the process of implementing a new small group is complex, requiring careful organization.

Theologically, the gifts of administration and equipping are as essential for an effective small-group ministry as for other ministries in the church.

\section{Recruiting and Training Lay Leaders}

Small-group ministry thrives on the gift of leadership. Group leaders have tremendous roles to play. Cho mentions that "selecting right lay leaders is essential. Success or failure can depend on them. The first thing the pastor should do is look for men and women who are spirit filled."2

Effective group leadership requires particular abilities and developed skills. When it comes to discovering and motivating lay leaders in the ministry, recruiting and training are essential twins in the process.

\footnotetext{
${ }^{1}$ Thomas G. Kirkpatrick; Small Groups in the Church: A Handbook for Creating Community (Bethesda, MD: Alban Institute, 1995), 33 .

${ }^{2}$ Paul Yonggi Cho, "The Pastor's Devotional Life," Church Growth 4, no. 1 (March 1985): 4 .
} 
Lindgren and Shawchuck.mention that "training is the key to releasing the potential for ministry that is resident in the congregation. Good recruitment identifies workers. Training empowers them to be effective in the job they have accepted responsibility to do." 1

The Recruitment of Lay Leaders

Selection of potential small-group leaders should receive the same kind of attention as does the selection of other church offices. Because the task of selecting smallgroup leaders is similar to recruiting church officers, the coordinating committee's selecting process is like that of a church nominating committee.

It is necessary to follow several steps in that selection: (1) List qualities for prospective nominees, select prospective small-group leaders, and (3) contact prospective leaders.

\section{Listing Qualities}

The pastor needs to ask the coordinating committee to generate a list of desirable qualities for effective smallgroup leaders. Clinebell suggests the following criteria:

1. Had they displayed an inner genuineness and openness, and shown themselves to be a well-integrated person?

${ }^{1}$ Lindgren and Shawchuck, 113. 
2. Were they persons who displayed an unconditional positive regard for others? This was seen as having demonstrated a mixture of warmth, liking, caring, acceptance, interest, and respect for other persons.

3. Did they show their own ability for empathetic understanding of another person's situation? This means they must be people who are not overly invested in themselves because if they were, they would not be able to enter into another's world.

4. Did they demonstrate a firm sense of their own identity and worth?

5. Did they have a strong commitment to Christ and the Christian Eaith?'

A list of qualities such as shown above can serve as a guideline to discover people who have or who are likely to develop such characteristics. Once the coordinating committee reaches a consensus on the qualities, it is ready to assemble and prioritize a list of prospects.

\section{Selecting the Leaders}

To discover candidates for leading small groups, the committee should survey the church membership directory. ${ }^{2}$

\footnotetext{
${ }^{1}$ Howard J. Clinebell, Jr., "Experiments in Training Laity for Ministry," Pastoral Psychology 22, no. 215 (June 1971): 35 .

${ }^{2}$ I gleaned most of the concepts in this part from Kirkpatrick. His book Small Groups in the Church: A Handbook for Creating Community presents the step-by-step process that shows a viable way to plan for small groups.
} 
This helps the committee to consider everyone in the congregation--not just those who come to mind or who are already serving in other leadership positions.

During this phase of survey, committee members work individually to generate a list of leader candidates. Then the committee members can compare notes and decide whom to ask to consider this ministry. One good way to achieve consensus is to list all the candidates on a blackboard. Then the committee members discuss each candidate's qualifications for leading a small group.

The process should not neglect on any ground anyone whose name is suggested other than that the person does not fit the adopted qualities as an effective group leader. The pastor needs to take great care to ensure that the selection represents the church's diversity.

\section{Contacting Leaders}

Contacting the candidates is the next step. Who should contact the potential small-group leaders? That depends on who is most likely to persuade a candidate to give serious consideration to the call. In most cases, the pastor is the most desirable one to make the contact in the hope that people will take this call more seriously than if a lay person or other staff member makes the contact.

In the larger church, two lay committee members and one clergy committee member can share equally in making the 
contacts. The contacting can be done either face to face or by telephone.

\section{Training the Lay Leaders}

The church must prioritize leadership training over other activities. The church needs to pay any price to hold periodic leadership training if the church wants to reap more fruit for the kingdom of God.1

Any church that wants to have effective, functional leaders should plan satisfactory training programs to prepare the leaders for their tasks.

The pastor can select several methods for leadership training. Three of them are most available for local churches: retreats, seminars, and workshops. ${ }^{2}$

The Retreat

The most common periodical leadership-training method in the local church is the retreat. The church can have a retreat during school holidays or over long weekends. The retreat has its roots in the gospel when Jesus told His disciples, "Come with me by yourselves to a quiet place and get some rest" (Mark 6:31). The Nelsons confirm that "retreating was common to Jesus and his disciples. . . .

${ }^{1}$ Joshua B. Jokiman, "Developing Leadership in the Local Church" (D.Min. dissertation, Fuller Theological Seminary, 1987; Ann Arbor, MI: University Microfilms International, 1988), 154 .

$$
{ }^{2} \text { Ibid., } 139-150 \text {. }
$$


They could be alone for prayer, teaching, reflection, and instruction." 1

\section{A seminar for the Laity}

A seminar should be planned for the laity according to their spiritual needs and arranged through the local church board. Some conference administrators and laypersons who have the experience and skill of the ministry may be invited to assist.

\section{Purpose}

The purpose of the seminar is to help the laity who want to work or who are participating in volunteer ministry in the Seventh-day Adventist church in the South Caribbean Conference. The seminar will teach them the New Testament concepts of the church and its ministry and will instruct them how they should function in their roles as the laity provides effective volunteer ministry.

Further, the seminar makes the laity aware of the analysis of church ministry programs and of the biblical principles needed to develop a volunteer spirit and ability for both laity and ministry. As they understand the nature of the church, its ministry, and the role of the laity in the old and New Testaments, the laity will be better prepared to accept their responsibilities as volunteers.

\footnotetext{
${ }^{1}$ Virgil Nelson and Lynn Nelson, Retreat Handbook: A-Way to Meaning (Valley Forge, PA: Judson. Press, 1976), 8.
} 


\section{Participants}

The number of participants can be determined according to the size of the church. A suggested number of participants would be a minimum of five to a maximum of twenty. If the group is too small, the seminar may be considered unimportant. On the other hand, an oversized group could restrict participation and personal involvement. Each church member, current leader, and potential leader can participate in this seminar.

Goals

This seminar is designed to fulfill four main goals:

1. To acquaint the laity with the church ministry programs in the South Caribbean Conference.

2. To teach the laity about the importance of empowering and equipping the laity.

3. To introduce the laity to biblical principles to motivate and train other people.

4. To show the laity effective empowering and equipping strategies for the Seventh-day Adventist church in the South Caribbean Conference. The final goal of the seminar is the spiritual growth of the laity and the proclamation of the gospel.

Jonas Edson Arrais Matos; "A Lay-leadership Training Program for the Seventh-day Adventist Church in Brazil" (D.Min. dissertation, Andrews University, Berrien Springs, MI, 1997), 170 . 


\section{Schedule}

The date for the seminar should be established well in advance and time should be reserved on the church calendar. Since church members usually are more available for church activities on weekends, the goal will be to use Friday, Saturday, and Sunday for three weekends.

The proposed seminar for three weekends would not include consecutive weekends. Seventh-day Adventist pastors in the South Caribbean Conference usually have two or three churches in which they conduct worship, church board meetings, and other activities. Considering this situation, the seminar would take three months. Practically speaking, long-term training is more productive for participants to assimilate all the lessons and to share opinions.

The time and length of the seminar should be defined according to the situation of each church. ${ }^{1}$ The seminar will include prayer, discussion, lecture, and feedback. One suggested schedule for the weekend could be as follows:

1. Friday (evening), 7:00-9:00. Should include thirty minutes for greeting, instruction, and group discussion, followed by two classes of forty minutes each with two fiveminute breaks in each.

2. Sabbath (afternoon), 3:00-6:00. Should include three group discussions of fifteen minutes, three classes of forty minutes each, and three breaks of five minutes each.

\footnotetext{
${ }^{1}$ Ibid. , $168-169$.
} 
3. Sunday (morning), 9:00-12:00. Should include two group discussions of fifteen minutes each, two classes of forty minutes each, and a one-hour feedback session at the end of the seminar. The total number of classes per weekend is seven. The Sunday meeting should end with a fellowship lunch for participants and their families.

\section{Location}

The best place to conduct the seminar is the local church because it is convenient for the participants to attend. The schedule makes it unnecessary for the pastor and the laity to be absent from their regular church services. The proposed hour for the seminar would not disrupt the regular church services. Furthermore, additional funds will not be spent for the rental of another location or for travel expenses.

\section{Seminar Content}

Suggested course outline:

1. Analysis of Church Ministry Programs

A. Overview of Church Ministry Programs in the South Caribbean Conference

B. Review of Programs

C. Comparison and Evaluation of Pastoral and Lay Ministry Programs

2. Biblical and Theological Perspectives for Empowering and Equipping 

A. The Importance of Empowering and Equipping
B. The Need for Empowering and Equipping
C. The Ministry of Jesus as a Model

3. The Role of the Laity
A. In the old Testament
B. In the New Testament
C. In the Writings of Ellen white

4. Strategies to Empower and Equip the Laity
A. Leading the Laity to Discover Their Spiritual Gifts
B. Empowering and Equipping the Laity
c. Motivating the Laity to Witness
D. Church structures to Facilitate a shared Ministry

\section{Evaluation}

The purpose of the evaluation is to assess how well the participants accomplished what they set out to do. It also will provide some guidance and suggestions about what should be done in the future. At the conclusion of the seminar, each participant will write a final evaluation. ${ }^{1}$ A careful evaluation needs to be made of everything in order to determine the best use of available resources. ${ }^{2}$ According to the evaluations, the pastor should improve the quality of seminar.

${ }^{1}$ See Appendix A for a suggested evaluation form for the ${ }^{2}$ Matos, 174 . 
the seminar to offer more effective teaching to meet the needs of the participants.

\section{Graduation}

Graduation is the highlight of the seminar and should be celebrated with a special program. The laity can receive a diploma or certificate for the completion of the course. At the final meeting, the pastor should report to the church what each of the graduates has accomplished and take advantage of the occasion to invite a new group of people for another seminar.

\section{Expected Results}

The seminar is expected to produce certain results:

1. To strengthen the spirituality of the laity and to create their deep commitment of the ministry

$$
\text { 2. To provide recognition of the importance of lay }
$$

volunteer service

3. To improve the leadership abilities and skills of church leaders to train their own members. 
CHAPTER 5

DEVELOPING A GIFT-CENTERED MINISTRY

Ministry in the South Caribbean Conference has been pastor-oriented. In order that the laity become more involved in their areas of giftedness, pastors need to develop a paradigm shift in empowering and equipping the laity. Pastors need to understand that ministry is a shared responsibility between pastors and members. This concept of ministry was discussed in chapter 4 .

Empowering and equipping the laity must be an integral aspect of the ministry of pastors. In this chapter, some pastoral qualities will be discussed which will enable pastors to empower and equip the laity. I will attempt to develop a gift ministry, assisting pastors to better understand the following: (1) understanding spiritual gifts, (2) discovering your own giftedness, and (3) helping others confirm their giftedness. Some suggestions will also be given for the design of seminars for pastors to learn their important role of empowering and equipping the laity.

\section{Pastoral Qualities}

Calvin Rock, in his book Church Leadership: A Call to Virtue, deals with.several virtues that reflect qualities of 
character for Christian leaders. He presents courage, trust, honesty, decisiveness, loyalty, and self-control among the most important qualities that must be present in Christian leadership. He says that "the church suffers or succeeds in proportion to the virtue of its leaders."1 Malphurs summarizes the fundamental qualities for effective Christian leadership: "Christian leaders are godly persons [character] who know where they are going [vision] and have followers [influence]."2

Godly Character

Godly character is the foundation of any leadership. ${ }^{3}$ Nothing is more important than this quality. It is the core element that qualifies any Christian to lead others. ${ }^{4}$ Taylor points out that "a man or woman of character is a person not only of sterling integrity but of courage, discipline, perseverance, and rock-ribbed stability." ${ }^{5} \mathrm{~A}$ godly character earns people's respect and produces trust-the most essential ingredient in al.l pastoral leadership.

\footnotetext{
${ }^{1}$ Calvin B. Rock, Church Leadership: A Call to Virtue (Boise, ID: Pacific Press, 1990), 8.

${ }^{2}$ Malphurs, Planting Growing Churches for the 2 ist Century, 126 .

${ }^{3}$ Warren Wiersbe and David Wiersbe, 10 Power Principles for Christian Service (Grand Rapids: Baker, 1997), 20.

${ }^{4} J o h n$ C. Maxwell, Developing the Leaders Around You (Nashville: Thomas Nelson, 1995), 47-48.

${ }^{5}$ Richard S. Taylor, Principles of Pastoral Success (Grand Rapids: Francis Asbrury, 1989), 51.
} 
Ted Engstrom presents the leadership characteristics of Moses as described in Heb 12: Moses had faith, integrity, and vision; he was decisive, obedient, and responsible $(\operatorname{vvs} .24-29) .^{1}$

Character is what Jesus described in the Beatitudes (Matt 5:3-12) and demonstrated in His own life and ministry in the gospels. Character is made up of those beautiful qualities that Paul called the "fruit of the spirit" in Gal 5:22-23. In this list, Paul sets the criteria for developing and measuring a Christian character. The sowing of such virtues is essential to develop effective christian leaders.

For warren wiersbe, a healthy and holy character is formed by making scripture a part of one's inner being and obeying what it says. It comes from faithfully spending time in prayer and diligent study of the Bible, gladly making sacrifices and willingly serving others. ${ }^{2}$ In character formation, one needs to consider the role of the Holy Spirit. The Holy spirit is the divine agent who transforms lives and develops Christian character. Ellen White writes that "the Christian life is not a modification or improvement of the old, but a transformation of the nature. There is a death to self and sin, and a new life

\footnotetext{
${ }^{1}$ Ted W. Engstrom, The Making of a Christian Leader (Grand Rapids: Zondervan, 1976), 30 .

${ }^{2}$ Wiersbe and Wiersbe, 20.
} 
altogether. This change can be brought about only by the effectual working of the Holy Spirit."1

Vision
Effective pastors are visionary leaders. According to Burt Nanus, "there is no more powerful engine driving an organization [church] toward excellence and long-range success than an attractive, worthwhile, and achievable vision of the future, widely shared." ${ }^{2}$ With vision, the leader provides the all-important bridge from the present to the future of the organization. A vision is an attempt to articulate, as clearly and vividly as possible, the desired future state of the church or organization. The vision is the goal that provides direction, aligns key players, and energizes people to achieve a common purpose. ${ }^{3}$ According to Warren's concept, "Vision is the ability to see the opportunities within your current circumstances. "4 James Cress goes. further, stating that vision helps the pastor and church members to look beyond the actual circumstances. "Those who cannot see beyond the immediacy of today will

${ }^{1}$ White, The Desire of Ages, 172.

${ }^{2}$ Burt Nanus, Visionary Leadership: Creating a Compelling Sense of Direction for Your Organization (San Francisco: Jossey-Bass, 1982), 3 .

${ }^{3}$ Ralph H. Kilmann and Teresa Joyce Covin, Corporate Transformation: Revitalizing Organizations for a Competitive World (San Francisco: Jossey-Bass, 1988), 135.

${ }^{4}$ Warren, 28 . 
seldom prepare for tomorrow." ${ }^{1}$ Thom Rainer points out that the pastor needs to "teach his church to be visionary."2

Some essential elements that may help develop an effective vision in the local congregation are the following:

1. An effective vision is inspiring and challenges people to accept ideas and transform them into action. Vision involves action. Visionary leadership demands intentional action in carefully selected areas of the church. Vision is not a fantasy or mere plans and goals; it is an attitude that is motivated to act and choose directions most likely to promote healthy and constant transformation. Effective vision happens when high purpose and intense pragmatism meet. ${ }^{3}$ It is true that a worthy vision may emerge from a dreamer's imagination, but it must be plausible and possible to put in action.

\section{Effective vision is clear, specific, and} communicable. Dale Galloway, in his book 20/20 Vision, describes how pastors can transfer or communicate their vision to the congregation. First it is necessary to get a clear picture of the vision. Second, a strong commitment

\footnotetext{
'James A. Cress, "How to Destroy Your Leadership," Ministry, January 1996, 30 .

${ }^{2}$ Thom S. Rainer, The Book of Church Growth: History, Theology, and Principles (Nashville: Broadman and Holman, 1993), 189 .

${ }^{3}$ Tom Peters and Nancy Austin, A Passion for Excellence (New York: Random, 1985), 490.
} 
must be made to make the vision become a reality. Third, prayer is offered for God to confirm the vision. Fourth, one must organize resources and concentrate on making the vision happen. Fifth, one must be willing to risk failure as he or she reaches out to fulfill the vision. Sixth, faith must be applied to it. ${ }^{1}$

3. An effective vision is both stable and flexible. It pursues stable goals but is continually adjusting through time. It must be open to change. ${ }^{2}$

4. An effective vision empowers and enables people to work together to accomplish tasks and reach goals. Pastors need to inspire their congregation with what is possible, have them participate in developing the vision, thereby helping them to own the vision, and then as a team work out the strategy to see that the vision becomes a reality. This process involves trust in people, to affirm them and to delegate to them their work to accomplish the task, focusing on priorities. ${ }^{3}$

5. Vision must be the fruit of faith and according to God's will. The pastor is key to provide vision; it seldom arises from the members. An effective vision is more than

${ }^{1}$ Dale E. Galloway, $20 / 20$ Vision: How to Create a Successful Church (Portland, OR: Scott, 1986), 33-41.

${ }^{2}$ Adapted from Barry $N$. Crane, "Teamwork: The Lay Leader's Guide to Church Growth" (D.Min. dissertation, Fuller Theological Seminary, 1992), 78-85.

${ }^{3}$ Ibid. 
something the leader has manufactured; it must be Biblebased and God-honoring. It must contribute to the expansion of God's cause and accomplish His purposes. It is not the development of a personality cult or an egocentric human enterprise. ${ }^{1}$

The Seventh-day Adventist Church in the South Caribbean Conference needs visionary pastors whose dreams and understanding of the mission of the church are open to new possibilities and paradigms, and who articulate a new, realistic, credible, attractive future for the church, a condition that is better in some important ways than what now exists.

\section{Influence}

Most definitions of leadership--both secular and Christian--include the concept of influence. The essence of leadership is influence. ${ }^{2}$ No matter how many definitions one applies to leadership, influence is the term that summarizes the nucleus of its meaning. The primary function of leadership is to direct and inspire behavior to obtain particular goals. ${ }^{3}$ J. Robert Clinton defines a Christian leader as one who brings the Christian influence into his

\section{'Ibid., 85.}

${ }^{2}$ John C. Maxwell, Developing the Leader Within You (Nashville: Thomas Nelson Publishers, 1995), 49, 105.

${ }^{3}$ Edgar J. Elliston, Home Grown Leaders. (Pasadena, CA: William Carey Library, 1992), 21. 
particular group or situation. He says that a leader is "a person with God-given capacity and with a God-given responsibility to influence a specific group of God's people toward God's purposes for the group."1 Malphurs says that Christian leaders exert a powerful influence on people. "They are like magnets in that they attract people. When they turn around and look behind them, they see people. Those who insist that they are leaders but have no one following them, are not leaders at all."2

The influence of Christian leaders has been a great power to touch and transform many lives. Christian leaders have the responsibility to influence people toward God's purpose. Christian leadership in Christ's church is to be concerned with the inner growth and development of the believer.

The influence of the pastor as a leader is not only a reality in the personal lives of the church members and outside community but in the whole process of church growth. In church growth literature, every source emphasizes the vital role played by pastoral leadership in facilitating and influencing growth. Peter Wagner, in Leading Your Church to Growth, declares that the first vital sign of a healthy growing church is "a pastor who is a possibility thinker and

${ }^{1} \mathrm{~J}$. Robert Clinton, The Making of a Leader (Colorado Springs, CO: NavPress, 1988), 245.

${ }^{2}$ Malphurs, Planting Growing Churches, 129. 
whose dynamic leadership has been used to catalyze the entire church into action for growth." ${ }^{1}$ Lyle schaller agrees with Wagner's concept that pastoral leadership is the "most critical single factor" for productive ministry resulting in church growth. ${ }^{2}$

Some of the essential qualifications which pastors should possess to have a commanding influence for good are the following.

The Love of Jesus

It is interesting to note that before His ascension, Jesus mentioned only one condition of discipleship to simon Peter. Jesus said to him, "Simon, son of Jonas, do you love me?" (John 21:16). Ellen White explained the meaning of Jesus' question to Peter.

The question that Christ had put to Peter was significant. He mentioned only one condition of discipleship and service. "Lovest thou Me?" He said. This is the essential qualification. Though Peter might possess every other, yet without the love of Christ he could not be a faithful shepherd over the Lord's flock. Knowledge, benevolence, eloquence, gratitude, and zeal are all aids in the good work; but without the love of Jesus in the heart, the work of the Christian minister is a failure. ${ }^{3}$

To possess the love of Jesus is the absolute qualification of discipleship just as the apostle Paul said, "And if I have prophetic powers, and understand all

${ }^{1}$ Wagner, Leading Your Church to Growth, 78.

${ }^{2}$ Schaller, 10 .

${ }^{3}$ White, The Desire of Ages, 815 . 
mysteries and all knowledge, and if I have all faith, so as to remove mountains, but have not love, I am nothing" ( 1 Cor $13: 2$ ).

How can one possess the love of Jesus in the heart? White said, "Walk continually in the light of God. Meditate day and night upon His character. Then you will see His beauty and rejoice in His goodness. Your heart will glow with a sense of His love."' Therefore, the pastor must be a student of the scripture and have time set apart for meditation and prayer.

\section{Consecration}

Workers for God are required in the spirit of entire consecration to resolve that, by the grace of Christ, they will be a living sacrifice. The apostle Paul said, "I am already on the point of being sacrificed" (2 Tim 4:6).

How can one consecrate him or herself to God? White said, "If Christ dwells in the heart, the soul will be so filled with His love. Love to Christ will be the spring of action. Those who feel the constraining love of God aim at perfect conformity to the will of their Redeemer."2

Consecration is not an obligation or compulsion, but a gift through the love of Christ. Paul said, "For the love of Christ urges us on" (2 Cor $5: 14)$. This should be the

\footnotetext{
${ }^{1}$ White, The Ministry of Healing, 514.

${ }^{2}$ White, Steps to Christ, 28.
} 
actuating principle of pastors' conduct; it is their motivating power.

\section{Humility}

Workers for God are required to an eminent degree to possess humility. They should be the farthest removed from pride and self-exaltation. Jesus declared John the Baptist to be the greatest of prophets; yet when asked if he were the Christ, John declared himself unworthy even to unloose his Master's sandals (John 1:19-27).

How did John the Baptist become such a humble man? He studied the scrolls of the prophets. By day and by night, Christ was his study and his meditation. Looking in faith to the Redeemer, John had risen to the height of selfabnegation. He had by nature the faults and weaknesses common to humanity; but the touch of divine love had transformed him. ${ }^{1}$

It is also important to understand the meaning of real humility. It does not mean sloth, weakness, or inability. On the contrary, true humility is widely different. White stated that

to be clothed with humility does not mean that we are to be dwarfs in intellect, deficient in aspiration, and cowardly in our lives, shunning burdens lest we fail to carry them successfully. Real humility fulfills God's purposes by depending upon His strength. ${ }^{2}$

${ }^{1}$ White, Testimonies for the church, 8:331-333.

${ }^{2}$ White, Christ's Object Lessons, 363. 
It can be said that Noah, Abraham, Moses, Daniel, John the Baptist, Paul, and, above all, Jesus were the examples of the humility which pastors should possess.

\section{Earnestness}

Pastors need to be energetic, earnest gospel workers, filled with a desire to give others the truth because a quiet, prayerful life alone does not satisfy the need of the world. The apostle Paul said, "Do not lag in zeal, be ardent in spirit, serve the Lord" (Rom 12:11).

How can one become an earnest and sincere soul winner? It depends on how well one knows the value of a soul. One may estimate its worth by remembering that for one sinner Christ would have laid down His life. When one sees those who are going down to death, he/she will not rest in quiet indifference and ease. His/her efforts for the recovery of sinners will be more earnest and tender. ${ }^{1}$

\section{Responsibility}

The apostle Peter wrote to those who labored in the gospel: "Feed the flock of God which is among you, taking the oversight thereof, not by constraint, but willingly; not for filthy lucre, but of a ready mind" (1 Pet 5:2).

${ }^{1}$ Ibid., $196-197$. 


\section{Gift-Centered Ministry Means Equipping ${ }^{1}$}

Equipping is the most important function of the pastor necessary for effective gift ministry. There can be no diversity in unity without the equipping ministry.

Spiritual gifts are "ministry" gifts that enable every member of Christ's body to be legitimately activated for service.

When a pastor can successfully fulfill this task through equipping for gift ministry, it saves him/her many frustrations. Equipping gets at the heart of directing a given group or congregation toward growth and maturity. If the pastor does not equip, he will be constantly enmeshed in a morass of secondary details that may tear him down and prohibit him from functioning as he ought. Equipping God's people cannot be overstressed when it has to do with gift ministry in the Body of Christ.

\section{Developing a Gift Ministry}

Gift ministry does two things very well for the ongoing ministry mentality of a congregation. The first is an awareness of personal ministry. When gift ministry is properly implanted, you suddenly find that the members are ready and willing to volunteer. In fact, they are more anxious than ever. They know their gifts, and what is more

James D. Simpson, "A Strategy for Strengthening the Small Church Through the Development of Spiritual Gifts" (D.Min. dissertation, Fuller Theological Seminary, 1985), 2532 . 
important is that they know God, through His Spirit, is commissioning His work through them.

When you, as pastor, equip for gift ministry, it is especially important that you make sure that (1) you believe that the member can do the particular ministry, (2) you have a clear understanding as to what gift the Holy Spirit has administered, and (3) you give all the necessary assistance the member may need. Equipping means more than counting heads, but making disciples for Christ.

Second, and perhaps most important, is that gift ministry gives a tremendous sense of common purpose and direction. Perhaps for the first time, the congregation as a whole will see the Great Commission. With such a perception, church growth is bound to happen numerically and spiritually. ${ }^{1}$

It cannot be disputed that the pastor who equips can do more than the one who tries to do most ministry himself. Without equipping for gift ministry a pastor is limited in strength, purpose, and vision. Equipping is the special function of helping members of the Body of Christ to find and use their spiritual gift or gifts for specific gift ministry. In fact, equipping is the major function of the office gifts of pastor and teacher (Eph 4:11-12).

Gift ministry is for the common good of all ( 1 Cor 12:7). Harmony is the rule, not the exception. In fact,

\footnotetext{
${ }^{1}$ Ibid., 26-27.
} 
there is no excuse for the pastor not fulfilling his divine function and making a continuing effort to equip his/her members with the freedom which effective gift ministry brings. Pastors must learn the ministry of equipping if they are to be effective in their leadership.

The failure to equip God's people for gift ministry must not be accepted, especially in this present day. In the Body of Christ today, the world over, there is a much needed renewed emphasis upon the study of spiritual gifts. To attain excellence in the Body of Christ, equipping for gift ministry is an absolute must. In the final analysis, the members will benefit in their personal lives by being happier, spiritually richer, and better adjusted.

\section{Gift-Oriented Ministry \\ outline}

Understanding Spiritual Gifts ${ }^{1}$

1. All believers are called to be ministers, using their God-given spiritual gifts.

A. Since all believers are called as "priests," we have all been gifted to minister to God and declare his greatness to the world.

- Isa 61:6a

- 1 Pet $2: 9$

- Rev $1: 6$

B. Each believer is given spiritual gifts according to the work of the spirit for the good of the Body of Christ and the building of the Kingdom.

- Rom $12: 6-8$

${ }^{1}$ Robert E. Logan and Thomas T. Clegg, Releasing Your Church's Potential (Carol Stream, IL: Church Smart Resources, $1998), 3$. 
Christ.

2. Godly leaders seek to mobilize the whole Body of

A. "It was he (Christ) who gave some to be apostles, some to be prophets, some to be evangelists, and some to be pastors and teachers, to prepare God's people for works of service, so that the Body of Christ may be built up.. . as each part does its work." - Eph 4:11-16

B. Spiritual gifts have already been given to each Christian. Our role is simply to release those gifts to function.

C. Priority must be given to helping members discover, develop and use their spiritual gifts and empower them to discern and fulfill their God-given passion and calling. fulfilled.

3. When people use their gifts, they are effective and

A. Training may be needed for the use of gifts to be fully effective.

B. Enthusiasm and effectiveness will grow in proportion to meaningful contribution in community.

4. Loving obedience is the first step to discovering giftedness.

A. There are scriptural commands that correspond to some of the spiritual gifts. For example:



B. As believers lovingly follow these directives, spiritual gifts will emerge naturally as God blesses beyond the ordinary. 
C. It is in doing the will of God by faith that you discover the will and power of God. Example: Lepers cleansed as they went in obedience to Jesus (Luke 17:14). ${ }^{1}$

Reflection Questions:

1. What is your understanding of spiritual gifts? Which gifts are available for use in your church? Make a list.

2. Which gifts do you see operating in your church?

3. Which gifts need to be recognized and released?

4. What factors in your church inhibit or block the natural growth and release of spiritual gifts?

Discovering Your Own Giftedness ${ }^{2}$

1. Recognize your motivational pattern.

A. At birth, God places with all people an intrinsic motivation to do a certain kind of work.

B: Discovering your motivational pattern should not be a mystery. People leave a trail of evidence throughout their life.

C. Process: identify and describe times of personal satisfaction and achievements. Then, look for the common threads, and your motivational pattern will clearly emerge.

D. All people, whether or not they are believers, have a motivational pattern. At regeneration, God also gives you:

- a new nature (desire to please God)

- spiritual gifts (special abilities to serve God)

- a unique calling (specific contribution for God's kingdom)

\footnotetext{
${ }^{1}$ Ibid., 4 .

${ }^{2}$ Ibid. , 5 .
} 
2. Confirm your spiritual gift mix.

Ask yourself the following questions to discern your spiritual gifts:

A. Joy: What ministry activities bring you personal satisfaction and fulfillment?

B. Insight: Do you spot special needs and/or problems in some situations that go beyond the perceptions of ordinary Christians? In what ways?

C. Results: Where have you been particulary effective? What ministry activities are easy for you to do? What behaviors do you seem to do repeatedly?

D. Confirmation: How have others in the Body of Christ affirmed and/or encouraged you in ministry?

3. Evaluate your temperament and personality.

A. Each person is uniquely "wired" in the way they respond to situations and people.

B. Knowing personality or temperament will help you:

- understand what kind of work environment is helpful to you.

- know how to work with others with different personalities.

- temper your instinctive responses to be most helpful to others.

c. Personality conflicts can be negotiated better when there is an understanding and appreciation for differences.

D. Evaluate using personality tests, such as the Myers-Briggs, along with feedback from others that know you.

4. Assess your life situation.

A. Although "the gifts and calling of God are irrevocable" (Rom 11:29), the ways they are actualized will depend in part on several factors, such as:

- age 
- career

- marriage and other relationships

- education

- children

B. Your life situation need not keep you from being obedient to what God is claling you do do now.

C. Consider what steps God is showing you to fulfill his call in your life.

5. Identify your passion.

A. Passion is a strong emotional stirring focused on a particular target group or need related to God's kingdom work.

B. Characteristics of godly passion:

- complementary with motivational pattern

- accentuated by spiritual gifts

- tempered by biblical responsibilities and life situation

- directed by God for his global purposes

C. You must gain a sense of where God is leading you to serve. If not, you will flounder. Discerning your "servant profile" will allow you to choose the right job or ministry so you make a significant contribution to advance God's Kingdom and gain ultimate satisfaction in your work.

6. Focus your ministry calling.

A. Ministry calling is the specific contribution that the Lord wants you to make at this time for his Kingdom in light of your motivational pattern, spiritual gifts, temperament, life situation and passion.

B. Too many believers have lives that are unfocused.

C. Process to discover your calling:

- seek the Lord

- examine your heart

- get involved at the level of your availability, maturity and giftedness

- seek godly counsel and guidance 
- develop a plan for personal and ministry growth

- seek mentoring and accountability relationships

- check your compass regularly

Helping Others Confirm Their Giftedness ${ }^{1}$

1. Re-envision your ministry in terms of how to use your ministry to release giftedness in people.

A. Seek God for his vision to mobilize the gifts of those in your ministry.

B. A superficial network of an existing model may leave people disillusioned as to the validity and importance of operating in their giftedness.

C. Evaluate all responsibilities in your area of ministry in light of the gifts needed for those roles.

2. Develop networks of leaders to help guide people into an appropriate ministry.

A. Contact ministry leaders for needs.

B. Check with small-group leaders for referrals.

C. Mobilize and train ministry consultants for guiding people.

3. Help people discern and develop their gifts.

A. Teach and confirm spiritual gifts.

B. Evaluate their personality and temperament.

C. Assess their life situation.

D. Focus their calling.

4. Use small groups to mobilize people for ministry.

A. The small group provides a place for people to know each other well enough to help them identify their gifts.

${ }^{1}$ Ibid. , 9. 
B. Small groups also provide a safe, nonthreatening environment for people to practice using their gifts.

C. How small-group leaders can facilitate people placement into ministry:

- spot giftedness

- assess maturity and passion

- challenge to use gifts

- involve in ministry

- encourage to try again

- celebrate victories

- coach for more effectiveness

Reflection Questions:

1. What opportunities are available for utilization of gifts in your ministry area?

2. What gifts are needed for each role/responsibility in your area of ministry?

3. How will you orient and equip those stepping into new areas of ministry?

4. Who will mentor new volunteers?

5. Who might be ready to be challenged to use their gifts in a new or more expanded way?

Equipping carries with it four basic ideas:

1. Sharing of ministry--An assigned ministry goes from the pastor to the member, and the member accepts the ministry on the basis of his particular gift or gifts. Form (one's assigned ministry) actually follows function (spiritual gift) at this point.

2. Sharing of responsibility--This is essential despite the challenges of the laity. The failure to pass on responsibility may be due to one's personal insecurity.

3. Acceptance of responsibility--If equipping is to be effective, the member must be genuinely willing to perform 
the ministry and must have the initiative to get it done on the basis of his spiritual gift. An exception to this willingness is rare indeed.

4. Acceptance of accountability--The member is still accountable to those over him/her in the Lord (Heb 13:7, 17). ${ }^{1}$

\section{Benefits of Equipping}

Equipping for gift ministry in the Body of Christ offers substantial benefits to the entire congregation because it helps to develop latent abilities already within the believer. Let us note a few benefits:

1. Improved understanding between levels of ministry-every member becomes important. The ground becomes level for all at the foot of the cross, and a deeper appreciation of unity is expressed.

2. Improved pastor-member relationships--a sense of team followership is expressed when each member is made to feel as important as the next. Also, pastors will learn to rely more on their members.

3. Increased ministry satisfaction and morale-equipping is a powerful means for sensitizing members to their spiritual job description. This means increased ministry awareness and willingness to help. When ministry becomes personal, members are more productive. This helps 
to develop a strong team spirit toward church growth. Ministry becomes an ongoing satisfaction. ${ }^{1}$

\section{Benefits to the Pastor}

1. Eases ministry pressures: Ministry is a shared responsibility.

2. Increases time for broader ministry: The pastor can specialize in ministry.

3. Increases potential for church growth: Pastors empower and equip members to be more productive in ministry.

\section{Benefits to Church Members}

1. Challenge and interest awareness--gift ministry gives members a chance to show what they can do to edify the Body and to glorify God.

2. Increases motivation awareness--the opportunities provided through equipping for gift ministry stimulate more effective church growth. If members find that they are successful at their ministry, their confidence and efforts to remain involved will increase.

3. Increases opportunity awareness--gift ministry provides opportunities for every member in the Body of Christ. No one is left out. In short, it encourages them both to minister more responsibly and to accept more responsibility in the future. ${ }^{2}$

\footnotetext{
${ }^{1}$ Ibid., 31 .

${ }^{2}$ Ibid. , 31 .
} 
Why Some Pastors Fail in Equipping

There are several reasons why pastors disregard this important function.

1. They believe the members will not be able to handle the assignment. They believe the members will not represent the ministry of the pastors.

2. They fear competition from members. They fear sharing credit with the members.

3. They are afraid of losing recognition. They are afraid that the members will excel in ministry.

4. They are fearful that their weaknesses will be exposed.

5. The feel they will not have the time to provide the necessary training. ${ }^{1}$

\section{How to Equip}

1. Conduct a study on spiritual gifts.

2. Help the members to discover their particular gift or gifts.

3. Encourage and motivate the members to involve themselves in developing their gifts.

4. Open up a place of ministry for the members whereby they can begin to use their gift or gifts.

\footnotetext{
${ }^{1}$ Ibid. , 32 .
} 
5. Maintain pastoral leadership by stressing interdependence, diversity within unity. ${ }^{1}$

\section{Training and Mobilizing Laity}

One of the top priorities of the local church should be to train members to work effectively according to their abilities. The necessary steps for training laity for ministry are these:

1: Identify the needs of the community.

2. Specify the ministries required to meet the needs.

3. Identify the necessary competencies required to perform the specified ministries.

4. Design a curriculum to teach the necessary competencies.

5. Identify an instructor who can teach the needed competencies in the most effective manner.

6. Identify the laity who have an aptitude for the needed ministry.

7. Provide the identified laity with the needed training by using the most effective teaching methods available to produce the necessary competencies.

8. Evaluate the laity in training to measure their progress toward the competency for performing the task. ${ }^{2}$

${ }^{1}$ Ibid.

${ }^{2}$ Reuben A. Hubbard, "Masterplanning for Church Growth" (D.Min. dissertation, Fuller Theological Seminary, 1985), 135136 . 
The reason a proper understanding of spiritual gifts is so important is that a charismatic understanding of spiritual gifts would assume that if a lay person has a certain gift, that he/she is automatically competent to perform the required task or ministry, while a noncharismatic approach would assume that competencies need to be taught and measured. Yet the non-charismatic approach would recognize that different. laity have different gifts and that not all should be trained for the same ministry. ${ }^{1}$ Jesus said, "Preach the gospel to every creature" (Mark 16:15). In order to reach the masses, the church must be well-organized. Programs need to be developed to reach every age group, every social strata, every type of need, and this will require a variety of programs and approaches and will require utilizing all the talents available in the congregation. This means targeting programs to certain groups.

Within any group of laity, there will be differing talents, hindrances, abilities, and limitations. In order to engage every member, lines of work need to be developed in which people from each category and with differing abilities can engage. It takes planning and effort to involve the talents of all the congregation, but doing this will lead to fellowship among the members, spiritual and numerical growth, and a greater impact on the community.

\footnotetext{
'Ibid., 137.
} 
Ministries need to be developed for every gift in the congregation; ministries that will engage every member of the church. Different members will be able to do different things, but each one can do something that contributes toward their own growth and the edification of the church. Laity feel more confident doing tasks for which they have been carefully trained and prepared. Training includes theory and the practice of the skills necessary to perform the task. Lay persons will more readily volunteer for assignments for which they know they will receive adequate training to perform. ${ }^{1}$

Ideal training includes instruction followed by opportunity for immediate application of the skills taught. Instruction that is appropriate for the entire congregation may be given at the Sabbath morning worship service if presented tastefully and in an appropriate manner. One of the pastor's major tasks is the training and facilitating of the laity in ministries appropriate to the mission of the church and utilizing the gifts and abilities of each member of the congregation.

Proper instruction, combined with opportunity for practice of the necessary skills and with appropriate printed instruction available (manuals, guides, lessons),

${ }^{1}$ Ibid., $142-143$. 
will result in optimum participation on the part of the laity.'

Beyond what the pastor is to do to assist the laity discover their gifts, is what the laity themselves can do to discover their own gifts. Peter Wagner lists these in a five-step process.

1. Explore the possibilities.

2. Experiment with as many as you can.

3. Examine your feelings.

4. Evaluate your effectiveness.

5. Expect confirmation from the Body. ${ }^{2}$

\section{Seminars for Pastors}

Seminars are planned for pastors and will be arranged through the conference office. Some conference administrators will be invited to assist. Not only will they feel part of the team, but the pastors will realize that the administrators support the program.

\section{Purpose of the Seminars}

The purpose of the seminars is to help pastors to train lay members who want to work or who are working as church leaders in the Seventh-day Adventist Church in the South Caribbean Conference. The seminar will teach them the New

${ }^{1}$ Ibid. , 144

${ }^{2}$ C. Peter Wagner, Your Spiritual Gifts Can Help Your Church Grow (Ventura, CA: Regal Books, 1990), 116-132. 
Testament concepts of the church and ministry and instruct them as to how they would function in their role as pastors to provide effective pastoral care for the church. They will learn their important role in relationship to the ministry of the laity.

Further, the seminars will teach pastors the biblical principles and skills for developing pastoral leadership and equipping strategies to train laity for ministry. As they understand the nature of the church, its ministry, and the role of the pastor and leadership in the New Testament, they will be better prepared to accept their role as equippers.

\section{Participants in the Seminar}

It is expected that all pastors of the local conference where the seminars are conducted would attend. A suggested number of participants would be five to eight pastors. If the group is too small, the seminars could be considered unimportant. On the other hand, an oversized group could restrict participation and personal involvement. The seminars are primarily to assist the pastors in understanding their role to empower and equip the laity for ministry.

\section{Goals for the Seminars}

The seminars have a short-term and a long-term goal. The short-term goal is to create an awareness in the pastors regarding the nature of the church, its ministry, the role 
of the pastor, and to prepare the pastors to become effective equippers of the laity for ministry.

The long-term goal of the seminars is to select a group of pastors who will complete both seminars. They should be qualified as instructors for the seminar at the end of twelve months. They also will be responsible for the ministry in the local church, especially in training new members. Ultimately, the long-term goal is to have an effective system in place for discipleship and nurturing of new believers.

Description of the First Seminar

The first seminar will be conducted for two days, from Sunday morning through Monday afternoon. These two days will avoid any conflict with the regular church program. The seminar will use a ten-hour format and will include two sermons on the mission of the church (Sunday night and Monday morning), lectures, discussion, and feedback. The following is a list of subjects that will be covered through the lectures and discussion groups for the first seminar.

Seminar Content

Suggested course outline:

1. Analysis of Church Ministry Programs

A. Overview of Church Ministry Programs in the South Caribbean Conference

B. Review of Programs 
C. Comparison and Evaluation of Pastoral and Lay Ministry Programs

2. Biblical and Theological Perspectives for Empowering and Equipping
A. The Importance of Empowering and Equipping
B. The Need for Empowering and Equipping
C. The Ministry of Jesus as a Model
D. The Role of the Pastor

3. Strategies to Empower and Equip the Laity

A. Leading the Laity to Discover Their spiritual Gifts

B. Empowering and Equipping the Laity

C. Motivating the Laity to Witness

D. Developing Church Structures to Facilitate a More Involved Ministry

The first seminar covers the above subjects chosen to establish the biblical perspective concerning the role of the pastor, Jesus' ministry, equipping the laity, and strategies to empower and equip the laity. The contents of those subjects have already been discussed in previous pages. These subjects should provide a clear understanding of the pastor's role and a vision of God's purpose for the church. This vision makes it possible for pastors to equip the laity for ministry. 
Description of the second Seminar

The second seminar should be held within six months and covers six more topics. During that period, the participants can implement the new ideas. The seminars should be offered as a continuous training program to educate the pastors to become equippers of the laity and instructors for the seminar. The subjects listed below are those to be covered for the second seminar.

Seminar Content

Developing a Gift-Centered Ministry

1. Pastoral Qualities

2. Developing a Gift Ministry

3. Benefits of Equipping

4. Benefits to the Pastor

5. Benefits to Church Members

6. Training and Mobilizing the Laity

\section{Components of the Seminars}

The components of the seminars consist of two sermons: one on Sunday night and one on Monday morning. One suggested schedule for the ten-hour seminar on Sunday morning through Monday afternoon includes a prayer, seven lectures of one hour each, four discussion periods of thirty minutes each, and a one-hour feedback session at the end of the seminar. The following is the contents of the program:

1. Prayer session--intercessory in nature. 
2. Guided group discussion--relevant questions and references are provided to help guide the participants in their group discussion of the topic.

3. Lectures--discussing subjects previously assigned for group discussion. The purpose for having the discussion first is to familiarize the participants with the subjects so they can participate during the lectures.

4. Feedback--time is provided for sharing the insights gained during the discussion groups.

\section{Instructors for the Seminars}

I plan to be the main instructor for the seminars. Conference personnel who have been through the seminars will be invited to assist in the presentations. The planning and organizing of the seminars are my responsibility.

\section{Evaluation of the Seminars}

The purpose of the evaluation is to assess how well the participants accomplished what they set out to do. It will also provide some guidance and hints about what should be done in the future. At the conclusion of the seminars, each participant will write a final evaluation. ${ }^{1}$ A careful evaluation needs to be made of everything in order to determine the best use of available resources.

\section{seminars.}

${ }^{1}$ See Appendix B for a suggested evaluation form for the 
Expected Results

The seminars are expected to produce certain results:

1. To strengthen the pastors' spirituality and to create their deep commitment to the ministry

2. To provide better relationships and to improve interaction between the pastor and church leaders

3. To enlighten the pastors regarding their primary role in relation to the laity in the church

4. To help pastors motivate, recruit, and train new leaders and to prepare them to minister to the local church and its community

5. To improve pastoral skills in accomplishing tasks in the church

6. To provide the recognition of importance of the work by the laity in the church. 
CHAPTER 6

SUMMARY, CONCLUSIONS, AND RECOMMENDATIONS

\section{Summary}

Empowering and equipping the laity for ministry is an ongoing process. In the process of equipping, Melvin steinbron describes the importance for pastors to consider that "being precedes doing." He says that pastors "need to be equipping at two levels: being and doing. Being focuses on what we are. Doing focuses on what we do."1

Maxwell presents three facets of an equipper that can be applied to the pastor: the equipper is a model, a leader who does the job, does it well, does it right, and does it with consistency. The equipper is a mentor, an advisor who has the vision of the organization and can communicate it to others. The equipper is an empowerer, one who can instill in the potential leader the desire and ability to do the work. He or she is able to lead, teach, and assess the progress of the person being equipped. ${ }^{2}$ The equipping role of the pastor has its foundation in Eph $4: 11,12$, and in the teaching of spiritual gifts. Pastors need to have a clear

${ }^{1}$ Steinbron, 97.

${ }^{2}$ Maxwel1, Developing the Leaders Around You, 84. 
understanding of their role as equippers. Pastors are not going to accomplish the mission of the church alone.

The biblical doctrines of the priesthood of all believers and spiritual gifts may be the main reason to mobilize church members to be involved in church ministry. The mobilization of laity into ministry depends in great measure on the pastors' ability to recognize that they cannot do all the work alone and that they need to empower and equip the laity for ministry.

Chapter 1 dealt with the statement of the problem, statement of the task, justification for the dissertation, purpose of the dissertation, limitations of the dissertation, overview of the dissertation, and the expectations of the dissertation.

Chapter 2 discussed the biblical and theological perspectives for empowering and equipping. Areas discussed were:

The Importance of Empowering and Equipping

The Need for Empowering and Equipping

The Ministry of Jesus as a Model

The Role of the Pastor

Chapter 3 gave an analysis of church ministry programs in the South Caribbean Conference. An overview of three equipping models was presented.

Chapter 4 suggested strategies to empower and equip the laity. The following were presented: 
Leading the Laity to Discover Their Spiritual Gifts Empowering and Equipping the Laity Motivating the Laity to Witness Developing Structures to Facilitate a Shared Ministry Seminars for the Laity to Develop Their Ministry Chapter 5 outlined pastoral seminars. This chapter focused on:

Pastoral Qualities

Gift-Centered Ministry

Developing a Gift Ministry

Seminars for Pastors for Empowering and Equipping the Laity .

\section{Conclusions}

Empowering and equipping is an indispensable ministry in a church. To make it optional is to neglect the training of new church members, older church members, and church leaders. A church cannot have a positive influence in community services without a prayerful, systematic training of its membership. With carefully correlated ongoing church membership training, a church can have an effective ministry which will enrich its gospel commission. This is the challenge of the ministry of membership training.

To assure the effectiveness of empowering church members, everything possible must be done to train and mobilize laity for ministry. 
Several things are involved in incorporating laity in ministry:

1. Master planning in the local church

2. Discovery of individual spiritual gifts

3. Developing ministries for employment of those gifts on the local church level

4. Lay training to develop competencies for ministry in identified areas of need

5. Personal visitation and recruitment of laity for ministry in the local church.

The doctrines of spiritual gifts and the priesthood of all believers need to be understood by pastors and members. The mobilization of church members to exercise their ministry should be based on their areas of giftedness. The role of the pastor is many-faceted. It is very clear that the main function is to equip the members to develop their own ministry in building up the church (Eph $4: 11,12$ ). As members are equipped and empowered, they become liberated to perform ministry.

Pastoral seminars for empowering and equipping the laity for ministry, according to their giftedness, provide fulfillment of their roles and functions. Pastors and members will discover new avenues of ministry. Such seminars can be catalysts for the church members to experience growth in ministry. 


\section{Recommendations}

Several recommendations have resulted from this research:

1. The Caribbean Union Conference and the South Caribbean Conference should offer effective, continual programs and supply the necessary materials to assist pastors to improve their leadership skills and resources to empower and equip the laity.

2. The South Caribbean Conference, with the support of the Caribbean Union Conference, should establish a training center so pastors and laity can participate in empowering and equipping according to their regional needs.

3. The South Caribbean Conference should publish an empowering and equipping syllabus to improve the ministry of pastors and laity.

4. The South Caribbean Conference should conduct training seminars for pastors, teaching them how to empower and equip the laity.

5. The South Caribbean Conference should create an annual budget for the specific purpose of assisting pastors to purchase materials and equipment to facilitate empowering and equipping the laity.

6. Caribbean Union College should add to its curriculum courses that will train pastors to empower and equip the laity. 
7. The pastoral seminars suggested should be improved, adapted, and used wherever needed for the benefit of pastors and laity. 
APPENDICES 
APPENDIX A

EVALUATION OF THE SEMINAR BY THE LAITY 
Looking back at the seminar, I obtained the following impressions (please circle the respective number of each scale):

1. I learned the importance of the personal devotional exercise.

$\begin{array}{llllllllllll}\text { Strongly disagree } & 1 & 2 & 3 & 4 & 5 & 6 & 7 & 8 & 9 & 10 & \text { Strongly agree }\end{array}$

2. I gained a clear understanding of the role of the laity in the church.

Strongly disagree $1 \begin{array}{lllllllllll}1 & 2 & 3 & 4 & 5 & 6 & 7 & 8 & 9 & 10 & \text { Strongly agree }\end{array}$

3. I am convinced of the importance of empowering and equipping the laity.

Strongly disagree $1 \begin{array}{lllllllllll}1 & 2 & 3 & 4 & 5 & 6 & 7 & 8 & 9 & 10 & \text { Strongly agree }\end{array}$

4. I learned practical principles and skills to develop a Christian leadership.

$\begin{array}{llllllllllll}\text { Strongly disagree } & 1 & 2 & 3 & 4 & 5 & 6 & 7 & 8 & 9 & 10 & \text { Strongly agree }\end{array}$

5. I learned some strategies to empower and equip the laity for ministry.

Strongly disagree $1 \begin{array}{lllllllllll}1 & 2 & 3 & 4 & 5 & 6 & 7 & 8 & 9 & 10 & \text { Strongly agree }\end{array}$

6. The opportunity for dialogue, contribution, and feedback was adequate.

$\begin{array}{llllllllllll}\text { Strongly disagree } & 1 & 2 & 3 & 4 & 5 & 6 & 7 & 8 & 9 & 10 & \text { Strongly agree }\end{array}$ 7. The lay training seminar should be repeated.

Strongly disagree $1 \begin{array}{lllllllllll}1 & 2 & 3 & 4 & 5 & 6 & 7 & 8 & 9 & 10 & \text { Strongly agree }\end{array}$

8. In my overall rating, the seminar was helpful and effective.

Strongly disagree $1 \begin{array}{lllllllllll}1 & 2 & 3 & 4 & 5 & 6 & 7 & 8 & 9 & 10 & \text { Strongly agree }\end{array}$

I have the following suggestions: 


\section{APPENDIX B}

EVALUATION OF THE SEMINARS BY THE PASTORS 
Looking back at the seminars, I obtained the following impressions (please circle the respective number of each scale):

1. I learned the importance of a devotional exercise.

$\begin{array}{llllllllllll}\text { Not at all } & 1 & 2 & 3 & 4 & 5 & 6 & 7 & 8 & 9 & 10 & \text { very much so }\end{array}$

2. I gained a clear understanding of the role of the pastor in the church.

$\begin{array}{llllllllllll}\text { Not at all } & 1 & 2 & 3 & 4 & 5 & 6 & 7 & 8 & 9 & 10 & \text { Very much so }\end{array}$

3. I am convinced of the importance of empowering and equipping the laity.

$\begin{array}{llllllllllll}\text { Not at all } & 1 & 2 & 3 & 4 & 5 & 6 & 7 & 8 & 9 & 10 & \text { Very much so }\end{array}$

4. I learned some strategies to empower and equip the laity for ministry.

$\begin{array}{llllllllllll}\text { Not at all } & 1 & 2 & 3 & 4 & 5 & 6 & 7 & 8 & 9 & 10 & \text { Very much so }\end{array}$

5. The opportunity for dialogue, contribution, and feedback was adequate.

$\begin{array}{llllllllllll}\text { Not at all } & 1 & 2 & 3 & 4 & 5 & 6 & 7 & 8 & 9 & 10 & \text { Very much so }\end{array}$

6. The pastoral training seminars should be repeated.

$\begin{array}{llllllllllll}\text { Not at all } & 1 & 2 & 3 & 4 & 5 & 6 & 7 & 8 & 9 & 10 & \text { Very much so }\end{array}$

7. In my overall rating, the course was helpful and effective.

$\begin{array}{llllllllllll}\text { Not at all } & 1 & 2 & 3 & 4 & 5 & 6 & 7 & 8 & 9 & 10 & \text { Very much so }\end{array}$

I have the following suggestions: 


\section{BIBLIOGRAPHY}

Adams, Arthur M. Pastoral Administration. Philadelphia: Westminster Press, 1964.

Armstrong, Richard Stoll. The Pastor-Evangelist in the Parish. Louisville, KY: Westminster/John Knox Press, 1990.

Arndt, William F., and F. Wilbur Gingrich. A Greek-English Lexicon of the New Testament and Other Early Christian Literature. Chicago: University of Chicago Press, 1979.

Balswick, Jack, and Walter Wright. A ComplementaryEmpowering Model of Ministerial Leadership. Pasadena, CA: Fuller Theological Seminary, 1987.

Barna, George. User Friendly Churches. Ventura, CA: Regal, 1992 .

Bass, Bernard M. Bass and Stogdill's Handbook of Leadership. New York: Free Press, 1990.

Bean, Sandra. "Spiritual Gifts: A Layperson's Perspective." Celebration, August 1995, 6.

Benjamin, Paul. The Equipping Ministry. Cincinnati, $\mathrm{OH}$ : Standard Publishers, 1978.

Bennis, Warren, and Burt Nanus. Leaders: Strategies for Taking Charge. . New York: Harper and Row, 1985.

Bergeror, Albert L. "A Strategy for Empowering the Church Through Biblical Leadership Development." D.Min. dissertation, Fuller Theological Seminary, Pasadena, CA, 1992.

Bilhi, Bob. Thirty Days to Confident Leadership. Nashville: Broadman and Holman, 1998.

Bobgan, Martin, and Martin Deirdre. Competent to Minister: The Biblical Care of Souls. Santa Barbara, CA: East Gate, 1996. 
Bolles, R. C. Theory of Motivation. New York: Harper and Row Publishers, 1967.

Bryant, Charles Vernon. Rediscovering the Charismata. Waco, TX: Word Books, 1986.

"Revitalizing Congregations Through Lay

Visitation Ministries." D.Min. dissertation, Drew University, Madison, NJ, 1987.

Burrill, Russell. Class notes, CHMN615 Evangelism and Church Growth. Berrien Springs, MI: Andrews University Theological Seminary, 1999.

- Revolution in the Church. Fallbrook, CA: Hart Research Center, 1993.

Cho, Paul Yonggi. "The Pastor's Devotional Life." Church Growth 4, no. 1 (March 1985): 4.

Successful Home-cell Groups. South Plainfield, NJ: Bridge Publication, 1981.

Christian, Dionisio C. "Developing and Implementing a Program of Instruction for Church Administrators and Ministers of the Antillian Union Conference of Seventhday Adventists to Enlarge Their Understanding of the Doctrine of Spiritual Gifts as It Relates to Their Roles and Functions." D.Min. dissertation, Andrews University, 1984 .

Clinebell, Howard J., Jr. "Experiments in Training Laity for Ministry." Pastoral Psychology 22, no. 215 (June 1971): 35 .

Clinton, Robert J. The Making of a Leader. Colorado Springs, CO: NavPress, 1988.

Coleman, Robert E. The Master Plan of Evangelism. Grand Rapids, MI: Fleming H. Revell, 1994.

Crane, Barry N. "Teamwork: The Lay Leader's Guide to Church Growth." D.Min. dissertation, Fuller Theological Seminary, 1992.

Cress, James A. "How to Destroy Your Leadership." Ministry, January 1996,30 .

Dean, Thomas. Religious Pluralism and Truth: Essays on Cross-Cultural Philosophy of Religion. Albany, NY: State University Press, 1995. 
DePree, Max. Leadership Is an Art. New York: Bantam Doubleday Dell, 1989.

Detwiler-Zapp, Diane, and William Caveness Dixon. Lay Caregiving. Philadelphia: Fortress Press, 1982.

Edwards, Rex D. Every Believer a Minister. Silver Spring, MD: General Conference of Seventh-day Adventists, 1995.

Elliston, Edgar J. Home Grown Leaders. Pasadena, CA: William Carey Library, 1992.

English, Edwin A. "An Evaluation of the Concept and Function of Mutual Ministry and Spiritual Gifts in the South Caribbean Conference." D.Min. dissertation, Andrews University, Berrien Springs, MI, 1974.

Engstrom, Ted W. The Making of a Christian Leader. Grand Rapids, MI: Zondervan, 1976.

Fowler, John. Adventist Pastoral Ministry. Boise, ID: Pacific Press Publishing Association, 1990.

Galloway, Dale E. 20/20 Vision: How to Create a Successful Church. Portland, OR: Scott, 1986.

Garlow, James L. Partners in Ministry: Laity and Pastors Working Together. Kansas City, MO: Beacon Hill Press, 1981.

George, Carl F. The Coming Church Revolution: Empowering Leaders for the Future. Grand Rapids, MI: Fleming $\mathrm{H}$. Revel1, 1994.

- Prepare Your Church for the Future. Grand Rapids, MI: Fleming H. Revell, 1996.

George, Carl F., and Robert E. Logan. Leading and Managing Your Church. Old Tappan, NJ: Fleming H. Revell, 1987.

Hadaway, C. Kirk. Church Growth Principles: Separating Fact from Fiction. Nashville: Broadman, 1991.

Holmes, C. Raymond, and Douglas Kilcher, eds. The Adventist Minister. Berrien Springs, MI: Andrews University Press, 1991.

Hubbard, Reuben A. "Masterplanning for Church Growth." D.Min. dissertation, Fuller Theological Seminary, Pasadena, CA, 1985. 
Hull, Bill. The Disciple Making Pastor. Old Tappan, NJ: Fleming $\mathrm{H}$. Revell, 1988 .

Johns, Gary. Organizational Behavior: Understanding Life at Work. Glenview, IL: Scott, Foresman, 1983.

Johnson, Douglas W. Empowering Lay Volunteers. Nashville: Abingdon Press, 1991.

Jokiman, Joshua B. "Developing Leadership in the Local Church." D.Min. dissertation, Fuller Theological Seminary, 1987.

Kerr, Wynall F. "A Proposal Strategy for Evangelizing the Hindus of the Republic of Trinidad and Tobago." D.Min. dissertation, Andrews University, Berrien Springs, MI, 1989 .

Kilcher, Douglas Robert. "Pastoral Morale and Motivation: The Relationship of selected Attitudes and Variables to Job Satisfaction With a View to Increasing Ministerial Effectiveness." D.Min. dissertation, Fuller Theological Seminary, Pasadena, CA, 1987.

Kilmann, Ralph H., and Teresa Joyce Covin. Corporate Transformation: Revitalizing Organizations for a Competitive World. San Francisco: Jossey-Bass, 1988.

Kirkpatrick, Thomas G. Small Groups in the Church: A Handbook for Creating Community. Bethesda, MD: Alban Institute, 1995.

Lall, Bernard M., and Geeta R. Lall: New Dynamic Leadership. Berrien Springs, MI: Geetanjali Publishers, 1994 .

Lindgren, Alvin J. Foundations for Purposeful Church Administration. Nashville: Abingdon Press, 1965.

Lindgren, Alvin J., and Norman Shawchuck. Let My People Go: Empowering Laity for Ministry. Nashville: Abingdon, 1980.

Logan, Robert E., and Thomas T. Clegg. Releasing Your Church's Potential. Carol stream, IL: Churchsmart Resources, 1998.

Lopa, Aaron M. "The Role of the Pastor in Lay Development in the Seventh-day Adventist Church in Papua New Guinea." D.Min. dissertation, Andrews University, 1996. 
MacArthur, John F., Jr. The MacArthur New Testament Commentary: Ephesians. Chicago: Moody Press, 1986.

Mager, Robert F. Preparing Instructional objectives. Palo Alto, CA: Fearson Publishers, 1962.

Mallory, Sue, and Brad Smith. The Equipping Church Guidebook. Grand Rapids, MI: Zondervan, 2001.

Malphurs, Aubrey. Developing Vision for Ministry in the 21st Century. Nashville: Abingdon, 1990.

Planting Growing Churches for the 21st Century. Grand Rapids, MI: Baker, 1992.

Manual for Ministers. Washington, DC: The Ministerial Association, General Conference of Seventh-day Adventists, 1977 .

Matos, Jonas Edson Arrais. "A Lay-leadership Training Program for the Seventh-day Adventist Church in Brazil." D.Min. dissertation, Andrews University, Berrien Springs, MI, 1997.

Maxwell, John C. Developing the Leaders Around You. Nashville: Thomas Nelson, 1995.

Developing the Leader Within You. Nashville: Thomas Nelson Publishers, 1995.

Menking, Stanley J. Helping Laity to Help Others. Philadelphia: Westminster Press, 1984.

Middlemist, R. Dennis, and Michael A. Hitt. Organizational Behavior: Managerial Strategies for Performance. St. Paul, MN: West, 1988 .

Miner, John B. Organizational Behavior: Performance and Productivity. New York: Random House, 1988.

Modad, Miled. "Developing and Implementing a Training Program in Public Evangelism for Lay Members of the Hispanic Seventh-day Adventist Churches in the Wisconsin Conference." D.Min. dissertation, Andrews University, Berrien Springs, MI, 1989.

Murray, Eric John. A History of the Seventh-day Adventist Church in Trinidad and Tobago, 1891-1981. Trinidad, West Indies: The College, 1982.

Naden, Roy. "The Holy Spirit and Evangelism." Ministry, March 1993, 9. 
Nanus, Burt. Visionary Leadership: Creating a Compelling Sense of Direction for Your Organization. San Francisco: Jossey-Bass, 1982.

Nelson, Virgil, and Lynn Nelson. Retreat Handbook: A-Way to Meaning. Valley Forge, PA: Judson Press, 1976.

Niebuhr, Richard $\mathrm{H}$. The Purpose of the Church and Its Ministry. New York: Harper and Bros., 1956.

Nogueira, Paulo Cesar. "Equipping Laity for Ministry in Multi-Church Districts in Brazil." D.Min. dissertation, Andrews University, 1999.

Norton, Ricardo. Class notes, CHMN638 Seminar in Leadership. Berrien Springs, MI: Andrews University Theological Seminary, 1998.

- Class notes, CHMN664 Equipping Lay Leaders for Church Growth. Berrien Springs, MI: Andrews University Theological Seminary, 1999.

Ogden, Greg. The New Reformation: Returning Ministry to the People of God. Grand Rapids, MI: Zondervan, 1990.

Pedersen, Paul. Multiculturalism as a Fourth Force. Castleton, NY: Hamilton Printing Company, 1999.

Peters, Tom, and Nancy Austin. A Passion for Excellence. New York: Random, 1985.

Purkiser, W. T. The New Testament Image of the Ministry. Grand Rapids, MI: Baker Book House, 1970.

Rainer, Thom S. The Book of Church Growth: History, Theology and Principles. Nashville: Broadman and Holman, 1993.

Rice, George E., and Neal C. Wilson. The Power of the Spirit. Hagerstown, MD: Review and Herald Pub. Assn., 1991.

Rock, Calvin B. Church Leadership: A Call to Virtue. Boise, ID: Pacific Press, 1990.

Schaller, Lyle. The Senior Minister. Nashville: Abingdon Press, 1988 .

Seventh-day Adventist Yearbook. Hagerstown, MD: Review and Herald Pub. Assn., 1984, 2001. 
Shawchuck, Norman, and Gustave Rath. Benchmarks of Quality in the Church: 21 Ways to Continuously Improve the Content of Your Ministry. Nashville: Abingdon, 1994.

Simpson, James D. "A Strategy for Strengthening the Small Church Through the Development of Spiritual Gifts." D.Min. dissertation, Fuller Theological Seminary, 1985.

Slocum, Robert E. Maximize Your Ministry. Colorado Springs, CO: NavPress, 1992.

Smith, Donald P. Empowering Ministry: Ways to Grow in Effectiveness. Louisville, KY: Westminster/John Knox Press, 1996.

Snider, Lavern K. Whose Ministry? A Group Study Book on the Ministry of Every Christian. Osaka, Japan: Free Methodist Mission, 1975.

Steinbron, Melvin J. Can the Pastor Do It Alone? A Model for Preparing Lay People for Lay Pastoring. Ventura, CA: Regal, 1987.

Stevens, Paul R. The Equipper's Guide to Every-Member Ministry. Downers Grove, IL: Intervarsity Press, 1992.

Suzuki, Akeri. "Preparing Pastors to Train Laity for Church Growth in the Seventh-day Adventist Church in Japan." D.Min. dissertation, Andrews University, 1998.

Sweet, Leonard I. New Life in the Spirit. Philadelphia: Westminster Press, 1982.

Tangeman, Gary. The Disciple Making Church in the 21st Century. Fort Washington, PA: Christian Literature Crusade, 1996.

Taylor, Richard S. Principles of Pastoral Success. Grand Rapids, MI: Francis Asbrury, 1989.

Tidwell, Charles A. Church Administration: Effective Leadership for Ministry. Nashville: Broadman Press, 1985 .

Torrance, Thomas. "Foundation of the Church." In Theological Foundations for Ministry, ed. Ray S. Anderson. Grand Rapids, MI: Wm. B. Eerdmans Publishing Company, 1979 .

Wagner, C. Peter. Church Planting for a Greater Harvest. Ventura, CA: Regal Books, 1990. 
- Leading Your Church to Growth. Ventura, CA:

Regal Books, 1984.

1976

Your Church Can Grow. Glendale, CA: Regal Books,

Your Church Can Grow: Seven Vital Signs of a

Heal thy Church. Ventura, CA: G. L. Publishers, 1979.

- Your Spiritual Gifts Can Help Your Church Grow. Ventura, CA: Regal Books, 1990.

Warren, Rick. The Purpose-Driven Church. Grand Rapids, MI: Zondervan, 1995.

White, Ellen G. The Acts of the Apostles. Washington, DC: Review and Herald Publishing Association, 1946.

- Christian Service. Washington, DC: Review and Herald, 1958.

- Christ's Object Lessons. Washington, DC: Review and Herald, 1941.

- The Desire of Ages. Mountain View, CA: Pacific

Press Pub. Assn., 1940.

- "The Duty of the Minister and the People."

Review and Herald, July 9, 1895.

1952

Education. Mountain View, CA: Pacific Press,

. Evangelism. Washington, DC: Review and Herald,

1946 .

- Fundamentals of Christian Education. Washington, DC: Review and Herald, 1946.

- Gospel Workers. Washington, DC: Review and Herald Pub. Assn., 1915 (1948).

MS 24, 1887. Ellen G. White Research Center,

Andrews University, Berrien Springs, MI.

. MS 48, March 29, 1899. Ellen G. White Research

Center, Andrews University, Berrien Springs, MI.

- The Ministry of Healing. Mountain View, CA:

Pacific Press, 1958. 
- Pastoral Ministry. Silver Spring, MD: General Conference of Seventh-day Adventists, 1995.

"Sabbath Reform Needed.". Review and Herald, March 18,1884 .

- 'Selected Messages. Washington, DC: Review and $\because$ Herald,. 1958.

- Steps to Christ. Mountain View, CA: Pacific

Press Pub. Assn., 1956.

Testimonies for the Church. 9 vols. Mountain

View, CA: Pacific Press Pub. Assn., 1948.

Wiersbe, Warren, and David Wiérsbe. 10 Power Principles for Christian Sérvice. Grand Rapids, MI: Baker, 1997.

Williams, Dennis E., and Kenneth O. Gangel. Volunteers for Today's Church: How to Recruit and Retain Workers. Grand Rapids;" MI: Baker, 1993.

Wilson, Marlene. How to Mobilize Church Volunteers.

Minneapolis, MN: Augsburg Publishing House, 1983. 
1989-90 District Pastor, Valencia District, Trinidad, WI

1990-93 District Pastor, Siparia District, Trinidad, WI

1993-94 District Pastor, Point Fortin District, Trinidad, WI

1994-98 District Pastor, Sangre Grande District, Trinidad, WI 